\title{
Application of statistical methods for "flow unit" identification and characterization of a reservoir using well log and core data
}

\author{
Reza Mustafa \\ West Virginia University
}

Follow this and additional works at: https://researchrepository.wvu.edu/etd

\section{Recommended Citation}

Mustafa, Reza, "Application of statistical methods for "flow unit" identification and characterization of a reservoir using well log and core data" (2003). Graduate Theses, Dissertations, and Problem Reports. 1330.

https://researchrepository.wvu.edu/etd/1330

This Thesis is protected by copyright and/or related rights. It has been brought to you by the The Research Repository @ WVU with permission from the rights-holder(s). You are free to use this Thesis in any way that is permitted by the copyright and related rights legislation that applies to your use. For other uses you must obtain permission from the rights-holder(s) directly, unless additional rights are indicated by a Creative Commons license in the record and/ or on the work itself. This Thesis has been accepted for inclusion in WVU Graduate Theses, Dissertations, and Problem Reports collection by an authorized administrator of The Research Repository @ WVU. For more information, please contact researchrepository@mail.wvu.edu. 


\title{
APPLICATION OF STATISTICAL METHODS FOR "FLOW UNIT" IDENTIFICATION AND CHARACTERIZATION OF A RESERVOIR USING WELL LOG AND CORE DATA
}

\author{
Reza Mustafa
}

Thesis Submitted to the

College of Engineering and Mineral Resources

At West Virginia University

In partial fulfillment of the requirements

For the degree of

Master of Science

In

Petroleum and Natural Gas Engineering

Khashayar Aminian, Ph.D., Chair

Samuel Ameri, M.S.

Ilkin Bilgesu, Ph.D.

Daniel Della-Giustina, Ph.D.

Department of Petroleum and Natural Gas Engineering

Morgantown, West Virginia

2003

Keywords: Petroleum and Natural Gas Engineering, Flow Unit, Statistical

Zonation Technique, Reservoir Characterization.

Copyright 2003 Reza Mustafa 


\section{ABSTRACT \\ APPLICATION OF STATISTICAL METHODS FOR "FLOW UNIT" IDENTIFICATION AND CHARACTERIZATION OF A RESERVOIR USING WELL LOG AND CORE DATA Reza Mustafa}

A flow unit is a stratigraphically continuous interval of similar reservoir process speed that maintains the geologic framework and characteristics of rock types. Permeability and porosity of the reservoir rock has always been considered as two of the most important parameters to identify flow unit for formation evaluation, reservoir description, and characterization. Beyond evaluating permeability and porosity, one can also use combinations of two or more rock properties to gain insight into the character of two through porous media. Porosity is commonly evaluated from the well log data, which are usually available from the most wells in the reservoir. But permeability values, which are generally determined from the core analysis, are not usually available. The need for permeability values significantly limits the identification of Flow Units in reservoirs where core analysis is not abundant.

In this study, in a complex reservoir in West Virginia was successfully characterized using Flow Unit modeling. A linear relationship established between the $\log$ density and core permeability data in the cored wells was used to predict the permeability of the uncored wells, allowing for extension of flow units to these wells. Statistical methods were utilized using core permeability and predicted permeability data to identify and describe the Flow Unit in this reservoir. Then the Flow Units from well to well were correlated by statistical calculation to characterize the reservoir. 


\section{ACKNOWLEDGEMENTS}

First of all I thank my creator almighty Allah for giving me a safe and happy family life and also for courage, strength and stamina to complete this thesis.

I would like to take this opportunity to express my gratitude and appreciation to Dr. Khashayar Aminian, my academic and research advisor, for his invaluable guidance, support and dedication that made possible the completion of the study.

My appreciation to Professor Sam Ameri, Chairman of the Petroleum and Natural Gas Engineering Department, for his friendship and continuous advice during my stay at West Virginia University.

I will also like to extent my sincere appreciation to Dr. H. Ilkin Bilgesu who I found helpful at every single stage of this research work. Your valuable contributions are all appreciated.

Special thanks to Professor Daniel Della-Giustina for his encouragement participation in the examining committee.

I would also like to extend my appreciation to Ms. Beverly Matheny for her many hours of assistance and help for the past two years

To my uncle Mr. Shabbir Choudhuri for his continuous encouragement and advices from the very beginning of my MS study. 
For all of my friends, thanks for all that you have done for me.

Lastly and most importantly, I write of my wife, Nafisa Shams (Shoma). Her tireless support and believing that we could accomplish my goal has been steadfast. She has endured long days and nights of travel, managed the household with little help for me, and willingly gave up our time together for several years in order that I could accomplish my goal. She has earner my endless respect and appreciation for her unselfish support. I look forward to spending time with herthe one I love. 


\section{TABLE OF CONTENTS}

\section{Page}

$\begin{array}{lll}\text { ABSTRACT } & \text { ii }\end{array}$

ACKNOWLEDGEMENTS

TABLE OF CONTENTS V V

LIST OF FIGURES viii

LIST OF TABLES Xiv

NOMENCLATURE Xvi

\section{CHAPTER 1. INTRODUCTION}

CHAPTER 2. BACKGROUND AND THEORY

$2.1 \quad$ Description of the field 4

2.2 Collection of Data 6

$\begin{array}{lll}2.2 .1 & \text { Core Data } & 6\end{array}$

$\begin{array}{lll}\text { 2.2.2 Log Data } & 8\end{array}$

$\begin{array}{lll}2.3 & \text { Flow Unit } & 8\end{array}$

2.4 Techniques for identification of Flow Units 9

2.4.1 From Core Data $\quad 9$

$\begin{array}{lll}\text { 2.4.1.1 Histogram Approach } & 10\end{array}$

2.4.1.2 Probability Plot Approach 11 
$\begin{array}{ll}\text { 2.4.1.3 Ward's Algorithm } & 12\end{array}$

2.4.2 HU Prediction Using Log Data 12

$\begin{array}{lll}2.4 .3 & \text { Rank Correlation } & 13\end{array}$

$2.5 \quad$ Statistical Zonation Technique 14

CHAPTER 3. OBJECTIVE

\section{CHAPTER 4. METHODOLOGY}

4.1 Development of Permeability Prediction Model

4.1.1 Selection of Independent Variable 20

4.1.2 Functional Form of Model 21

$\begin{array}{lll}\text { 4.1.3 Scope and Assumption } & 23\end{array}$

$\begin{array}{lll}\text { 4.1.4 Model Validation } & 24\end{array}$

4.2 Flow Units Determination of Individual Wells 25

4.3 Correlation of Flow Units Between Adjacent Wells 27 
CHAPTER 5. RESULTS AND DISCUSSION

5.1 Discussion of results for Test $1 \quad 30$

5.2 Discussion of results for Test 2

5.3 Discussion of results for Test $3 \quad 37$

5.4 Discussion of results for Test $4 \quad 41$

$5.5 \quad$ Discussion of results for Test 5

5.6 Discussion of results for Test $6 \quad 46$

CHAPTER 6. CONCLUSIONS AND RECOMMENDATIONS

REFERENCES

Appendix A. Log Density and Core Permeability Distribution in 56 Cored Wells

Appendix B. Permeability Prediction in Cored Wells Using Linear 60 Correlation

Appendix C. Sample Calculation to identify Flow Units and their

67 Correlation 


\section{Page}

Appendix D. Determination of Flow Unit with Core Permeability by 74

Statistical Method in the Cored Wells

Appendix E. Determination of Flow Unit with Predicted Permeability

81 by Statistical Method.

Appendix F. Flow Unit in the cored wells based on original core

Permeability data.

Appendix G. Flow Unit identification with Predicted Permeability 92

Appendix H. Figure of Flow Unit Correlation 96

\section{LIST OF FIGURES}

Figure 2.1 Location of the Stringtown Field in West Virginia 5

Figure 2.2 Location of six Cored Wells in the Stringtown Field 7

Figure 4.1 Density Vs Permeability data taken from well F. R. Ball 22

19

Figure 4.2 Density Vs Logarithmic Permeability data from well F. R. 23

Ball 19

$\begin{array}{lll}\text { Figure } 5.1 & \text { (a) Comparison between predicted and original } & 31\end{array}$

$\begin{array}{ll}\text { permeability } & 31\end{array}$

(b) Comparison for Flow Units for Ball 18

Figure 5.2 Correlation of flow units for Development Data Set in 33 Test 1 (except Ball 18) 
Figure 5.3 Correlation of flow units for Development Data Set in 33 Test 1 with predicted flow unit of Ball 18.

Figure 5.4 Correlation of flow units from measured permeability data 34 for six cored wells.

$\begin{array}{lll}\text { Figure } 5.5 & \text { (a) Comparison between predicted and original } & 35\end{array}$

$\begin{array}{ll}\text { permeability } & 35\end{array}$

(b) Comparison for Flow Units for Ball 19

Figure 5.6 Correlation of flow units for Development Data Set in 36 Test 2 (except Ball 19)

Figure 5.7 Correlation of flow units for Development Data Set in 37 Test 2 with predicted flow unit of Ball 19.

$\begin{array}{lll}\text { Figure } 5.8 & \text { (a) Comparison between predicted and original } & 38\end{array}$

$\begin{array}{ll}\text { permeability } & 38\end{array}$

(b) Comparison for Flow Units for Lemasters 13

Figure 5.9 Correlation of flow units for Development Data Set in 39 Test 3 (except Lemasters 13)

Figure 5.10 Correlation of flow units for Development Data Set in 40 Test 3 with predicted flow unit of Lemasters 13.

$\begin{array}{lll}\text { Figure } 5.11 & \text { (a) Comparison between predicted and original } & 41\end{array}$

$\begin{array}{ll}\text { permeability } & 41\end{array}$

(b) Comparison for Flow Units for T. Heirs 8

Figure 5.12 Correlation of flow units for Development Data Set in 42 
Test 4 (except T. Heirs 8)

Figure 5.13 Correlation of flow units for Development Data Set in 43 Test 4 with predicted flow unit of T. Heirs 8 .

Figure $5.14 \quad$ (a) Comparison between predicted and original

permeability

(b) Comparison for Flow Units for P. Horner 9

Figure 5.15 Correlation of flow units for Development Data Set in

Test 5 (except P. Horner 9)

Figure 5.16 Correlation of flow units for Development Data Set in Test 5 with predicted flow unit of P. Horner 9.

Figure $5.17 \quad$ (a) Comparison between predicted and original

permeability

(b) Comparison for Flow Units for P. Horner 11

Figure 5.18 Correlation of flow units for Development Data Set in

Test 6 (except P. Horner 11)

Figure 5.19 Correlation of flow units for Development Data Set in Test 6 with predicted flow unit of P. Horner 11.

Figure A.1 Log Density and Core Permeability distribution for core well F. R. Ball 18

Figure A.2 Log Density and Core Permeability distribution for core well F. R. Ball 19

Figure A.3 Log Density and Core Permeability distribution for core 
well Lemasters 13

Figure A.4 Log Density and Core Permeability distribution for core 58 well T. Heirs 8

Figure A.5 Log Density and Core Permeability distribution for core well P. Horner 9

Figure A.6 Log Density and Core Permeability distribution for core well P. Horner 11

Figure B.1 Linear correlation between Density from well log and logarithmic core permeability for Test 1 (except Ball 18)

$\begin{array}{lll}\text { Figure B.2 Permeability Prediction for F. R. Ball } 18 & 61\end{array}$

Figure B.3 Linear correlation between Density from well log and 62 logarithmic core permeability for Test 2 (except Ball 19)

Figure B.4 Permeability Prediction for F. R. Ball 19

Figure B.5 Linear correlation between Density from well log and log 63 of core permeability for Test 3 (except Lemasters 13)

Figure B.6 Permeability Prediction for Lemasters 13

Figure B.7 Linear correlation between Density from well log and log 64 of core permeability for Test 4 (except T. Heirs 8 )

$\begin{array}{lll}\text { Figure B.8 Permeability Prediction for T. Heirs } 8 & 64\end{array}$

Figure B.9 Linear correlation between Density from well log and $\log \quad 65$ of core permeability for Test 5 (except P. Horner 9)

Figure B.10 Permeability Prediction for P. Horner 9 
Figure B.11 Linear correlation between Density from well log and log 66 of core permeability for Test 6 (except P. Horner 11)

Figure B.12 Permeability Prediction for P. Horner 11

Figure F.1 Flow Unit identification in F. R. Ball 18

Figure F.2 Flow Unit identification in F. R. Ball 19

Figure F.3 Flow Unit identification in Lemasters $13 \quad 90$

$\begin{array}{lll}\text { Figure F.4 Flow Unit identification in T. Heirs } 8 & 90\end{array}$

$\begin{array}{lll}\text { Figure F.5 Flow Unit identification in P. Horner } 9 & 91\end{array}$

Figure F.6 Flow Unit identification in P. Horner 11

Figure G.1 Flow Unit identification with Predicted Permeability for 93

Ball 18

Figure G.2 Flow Unit identification with Predicted Permeability for 93

Ball 18

Figure G.3 Flow Unit identification with Predicted Permeability for

Lemmasters 13

Figure G.4 Flow Unit identification with Predicted Permeability for

T. Heirs 8

Figure G.5 Flow Unit identification with Predicted Permeability for P. 95

Horner 9

Figure G.6 Flow Unit identification with Predicted Permeability for 95

P. Horner 11 
$\begin{array}{lll}\text { Figure H. } 1 \text { Correlation of flow units from six cored wells. } & 97\end{array}$

Figure H. 2 Correlation of flow units from five cored wells (except 97

Figure H. 3 Correlation of flow units between predicted Ball 18 and 98

$\begin{array}{lll} & \text { original five cored wells. } \\ \text { Figure H. } 4 & \text { Correlation of flow units from five cored wells (except } & 98\end{array}$

Figure H. 5 Correlation of flow units between predicted Ball 19 and 99

original five cored wells.

Figure H. 6 Correlation of flow units from five cored wells (except 99

Lemasters 13).

Figure H. 7 Correlation of flow units between predicted Lemasters $13 \quad 100$ and original five cored wells.

Figure H. 8 Correlation of flow units from five cored wells (except T. 100 Heirs 8).

Figure H. 9 Correlation of flow units between predicted T. Heirs 8 and 101 original five cored wells.

Figure H. 10 Correlation of flow units from five cored wells (except P. 101 Horner 9).

Figure H. 11 Correlation of flow units between predicted P. Horner $9 \quad 102$ and original five cored wells.

Figure H. 12 Correlation of flow units from five cored wells (except P. 102 Horner 11).

Figure H. 13 Correlation of flow units between predicted P. Horner $11 \quad 103$ and original five cored wells. 


\section{LIST OF TABLES}

Table 2.1 Core Analysis of Stringtown Oilfield 8

Table 4.1 Number of available core permeability data for six cored 24 wells

Table 4.2 List of six different tests performed 25

Table C.1 Rank of measured core permeability means for six wells in $\quad 69$ order of decreasing magnitude

Table C.2 Division of core permeability means into two zones. 71

Table C.3 Final division of core permeability means into two different 73 groups.

Table D.1 Flow Unit calculation for F. R. Ball 18 into two zones 75

Table D.2 Flow Unit calculation for F. R. Ball 18 into three zones 75

Table D.3 Flow Unit calculation for F. R. Ball 18 into four zones 76

Table D.4 Flow Unit calculation for F. R. Ball 19 into two zones 77

Table D.5 Flow Unit calculation for F. R. Ball 19 into three zones 78

Table D.6 Flow Unit calculation for Lemasters 13 into two zones 78

Table D.7 Flow Unit calculation for T. Heirs 8 into two zones 79

Table D.8 Flow Unit calculation for P. Horner 9 into two zones 79

Table D.9 Flow Unit calculation for P. Horner 11 into two zones 80

Table D.10 Flow Unit calculation for P. Horner 11 into three zones 80 
Table E.1 Flow Unit calculation for Predicted Permeability into two 82 zones for F. R. Ball 18

Table E.2 Flow Unit calculation for Predicted Permeability into three 82 zones for F. R. Ball 18

Table E.3 Flow Unit calculation for Predicted Permeability into two 83 zones for F. R. Ball 19

Table E.4 Flow Unit calculation for Predicted Permeability into three 84 zones for F. R. Ball 19

Table E.5 Flow Unit calculation for Predicted Permeability into two zones for Lemasters 13

Table E.6 Flow Unit calculation for Predicted Permeability into two zones for T. Heirs 8

Table E.7 Flow Unit calculation for Predicted Permeability into two 86 zones for P. Horner 9

Table E.8 Flow Unit calculation for Predicted Permeability into three 86 zones for P. Horner 9

Table E.9 Flow Unit calculation for Predicted Permeability into two zones for P. Horner 11

Table E.10 Flow Unit calculation for Predicted Permeability into three zones for P. Horner 11 


\section{Nomenclature:}

FU Flow Unit

k Permeability, $\mathrm{mD}$

B Variance between zones

L Number of zone

i the summation index for the number of zones

$\mathrm{m}_{\mathrm{i}} \quad$ the number of data in the ith zone

$\mathrm{k}_{\mathrm{i}} \quad$ the mean of the data in the ith zone

k.. the over-all mean of the data in the well

W the pooled variance within zones

$\mathrm{N} \quad$ the total number of data

$\mathrm{K}_{\mathrm{ij}} \quad$ the permeability data

$\mathrm{R}$ the zonation index

FZI Flow zone indicator

$\mathrm{n}_{\mathrm{h}}, \mathrm{n}_{\mathrm{i}}$ number of data in the hth and ith zones

S the standard deviation of all the permeability data from the reservoir

$\mathrm{Z}$ a constant tabulated as a function of the number of data, the number of zones and a probability level

$\mathrm{V}, \mathrm{P}$ the are used to identify $\mathrm{z}$ - values as function of the probability level

$\mathrm{F}_{\mathrm{p}}^{\prime} \quad \mathrm{S} * \mathrm{Z}$

RQI Reservoir quality index

$\tau \quad$ tortuousity 
$\mathrm{S}_{\mathrm{gv}}$ the effective surface area per unit grain volume

$\phi_{\mathrm{Z}} \quad$ the pore volume to grain volume ratio

F cumulative distribution, $0<\mathrm{F}<1$

Fs shape factor

$\mathrm{r}_{\mathrm{s}} \quad$ correlation number

f distribution density function

HU hydraulic unit

$\omega_{\mathrm{i}} \quad$ weight of ith HU distribution

$\sigma_{i} \quad$ standard deviation of ith distribution

$\mathrm{N}_{\mathrm{HU}} \quad$ number of hydraulic units

W within-cluster sums of squares 


\section{CHAPTER ONE INTRODUCTION}

The objective of the reservoir characterization process is to define the main petrophysical parameters needed to predict the flow of fluids within the porous formation. Among these parameters, permeability is one of the most important, since it influences the flow and sweep efficiency in any recovery process involving fluid injection, especially when lateral and vertical variations are present. Connected paths of high or low permeability values will condition the flow, therefore a reservoir description must be focused on identifying these different units that can be used to predict the reservoir.

One of the first problems encountered by the reservoir engineer in predicting or interpreting fluid displacement behavior during secondary processes is that of organizing and using the large amount of data available from core analysis. Permeabilities pose particular problems because they usually vary by more than an order of magnitude between different strata. Due to the sheer volume, it is almost always necessary to group data and to use an average value to represent a number of measurements. Perhaps the most common method now used to group permeability data is the capacity-friction technique, which ranks permeabilities in order of magnitude, regardless of the physical location of the permeabilities within the reservoir. 
Reservoir engineering techniques being developed will handle cross flow that occurs between adjacent communicating reservoir strata because of imbibitions and gravity segregation. Since crossflow occurs between physically adjacent layers within the reservoir, a flow unit technique recognizing the actual location of strata within the reservoir is necessary. Similarly, the recognition of natural flow unit is important for predictions of oil recovery by processes involving diffusion. One such process is miscible displacement, where predictions of lateral diffusion within the reservoir must recognize the actual location of the invaded zones in relation to the rest of the formation. Natural zones must also be adequately recognized to account for heat transfer within the reservoir during the thermal exploitation.

Because of the complexity of the problem, statistics appear to offer the only practical hope of dividing a reservoir into physically - meaningful natural flow units. In this thesis a statistical technique for identifying these natural flow unit and for ascertaining which ones are likely to be continuous between adjacent wells. The flow units defined have minimum variation of permeability internally and a maximum variation between zones. The technique is general and can thus be applied to reservoir properties other than permeability. However, a statistical correlation based on core permeabilities and log density in two different wells is no guarantee that the flow units so defined are, in fact continuous. Rather, the assumption of continuity must be consistent with geological data concerning the depositional environment, as well as justified on the basis of engineering 
judgment in combination with statistics, just as judgment is required with conventional zonation methods.

Although core data is not available for all wells due to excessive cost, a linear correlation has been made between core data and log data to predict permeability for uncored wells. The statistical method was utilized to identify the flow unit using the permeability data. The flow units from the predicted permeability and original core wells permeability were correlated with each other throughout the reservoir. The technique is particularly useful in describing the reservoir where cross flow between adjacent strata is important in determining reservoir behavior. 


\section{CHAPTER TWO}

\section{BACKGROUND AND THEOTY}

\subsection{Description of the field ${ }^{3}$}

The Stringtown Oil Field is located in the northwestern part of West Virginia, in Tyler, Wetzel and Doddridge Counties (Fig. 2.1) and was discovered in 1895. The

producing horizon ${ }^{(2,3)}$ in this field is the Upper Devonian Gordon Sandstone. On average, the pay zone starts at a depth of 2950 feet and is in the range from 10 to 25 feet in thickness, being thickest along a north-east and south-west trend, which is interpreted as shallow marine, shoreline deposits. Within the field, the Gordon interval consists of sandstone and thin inter-bedded shales and conglomerate. The field started its productive development as early as 1890 , however, due to some factors such as recurrent paraffin deposition and lack of durability of primary recovery, led the field to a rather low recovery. A gas-recycling project was initiated in mid 1940's, with poor results. Nevertheless, production has continued to present day. 
Figure 2.1. Location of the Stringtown Field in West Virginia

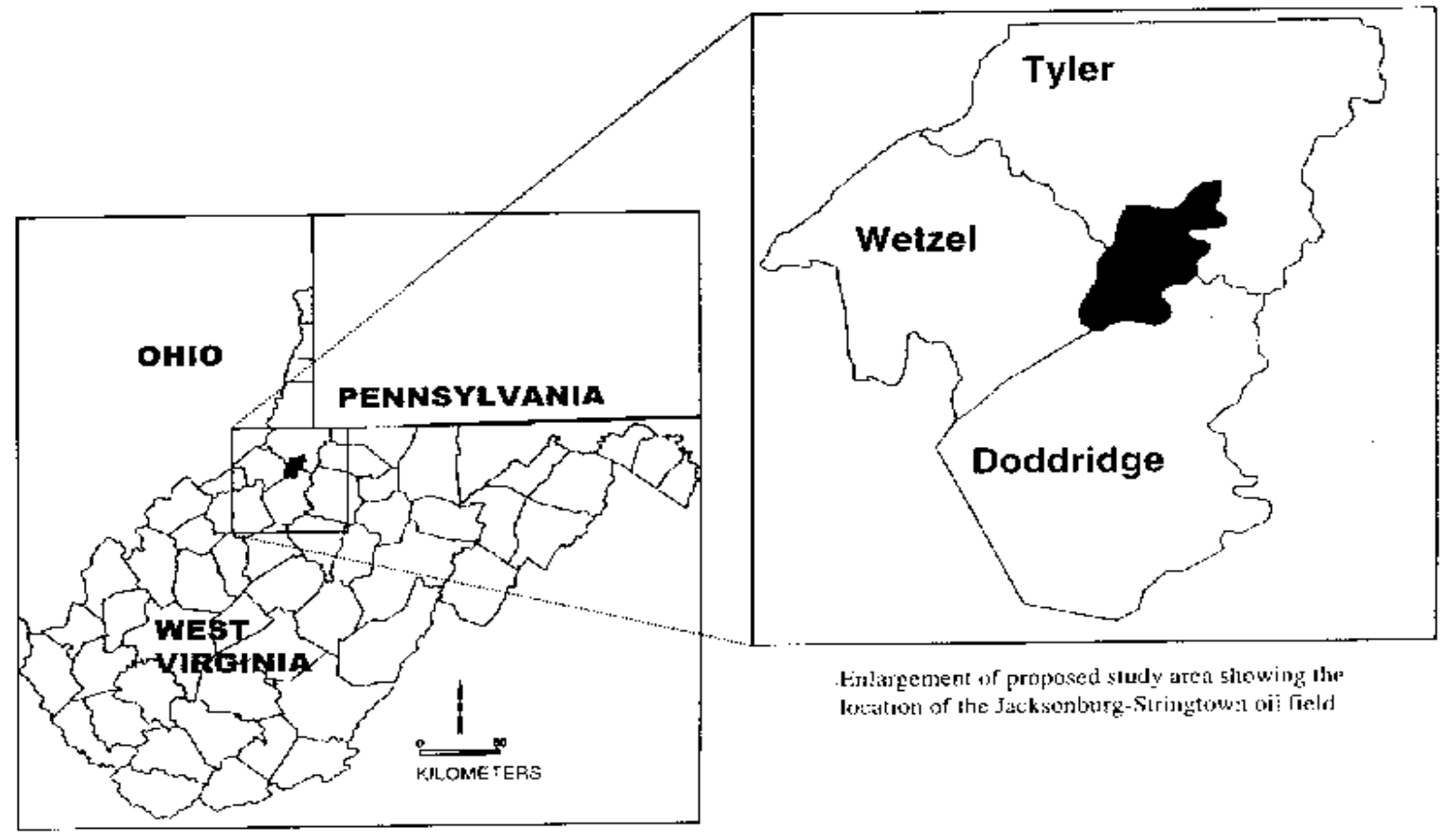

The field is roughly 5 miles long (north-south trend) and its width is about 2.5 miles, so the total productive area is approximately 8900 acres. The reservoir area is shaped like an inverted cone, wider in the north, narrower in the south. The oil in the Stringtown Field has a viscosity of $3.5 \mathrm{cp}$. at atmospheric pressure and $75^{\circ} \mathrm{F}$; gravity of $44^{\circ}$ API at $60^{\circ} \mathrm{F}$. Total oil production is estimated in some 13 millions barrels to date and the initial oil in place was estimated in 88.5 million barrels.

The Stringtown field has experienced two main periods of drilling since discovery. Over 500 wells were drilled before 1901, but most were plugged by 1910. More than 100 water injection wells and 40 new producing wells have been 
drilled since 1990 when a full-scale waterflood began after a successful pilot project initiated in a dual-five-spot pattern (33 acres) in 1980 and lasted until 1985. Total production from secondary oil operations resulted in an estimated recovery of 1.8 millions barrels.

\subsection{Collection of Data:}

Most of the data for this study was gathered from "Reservoir Characterization of Upper Devonian Gordon Sandstone" project. This project was a cooperation effort between Petroleum and Natural Gas Engineering and West Virginia Geologic and Economic Survey. Data were analyzed from cores and logs. The information from geologic interpretation of Gordon sandstone was also utilized.

\subsubsection{Core Data}

The results of core analysis were available from six cored wells located in the field as shown in Figure 2.2. 
Figure 2.2: Location of six Cored Wells in the Stringtown Field

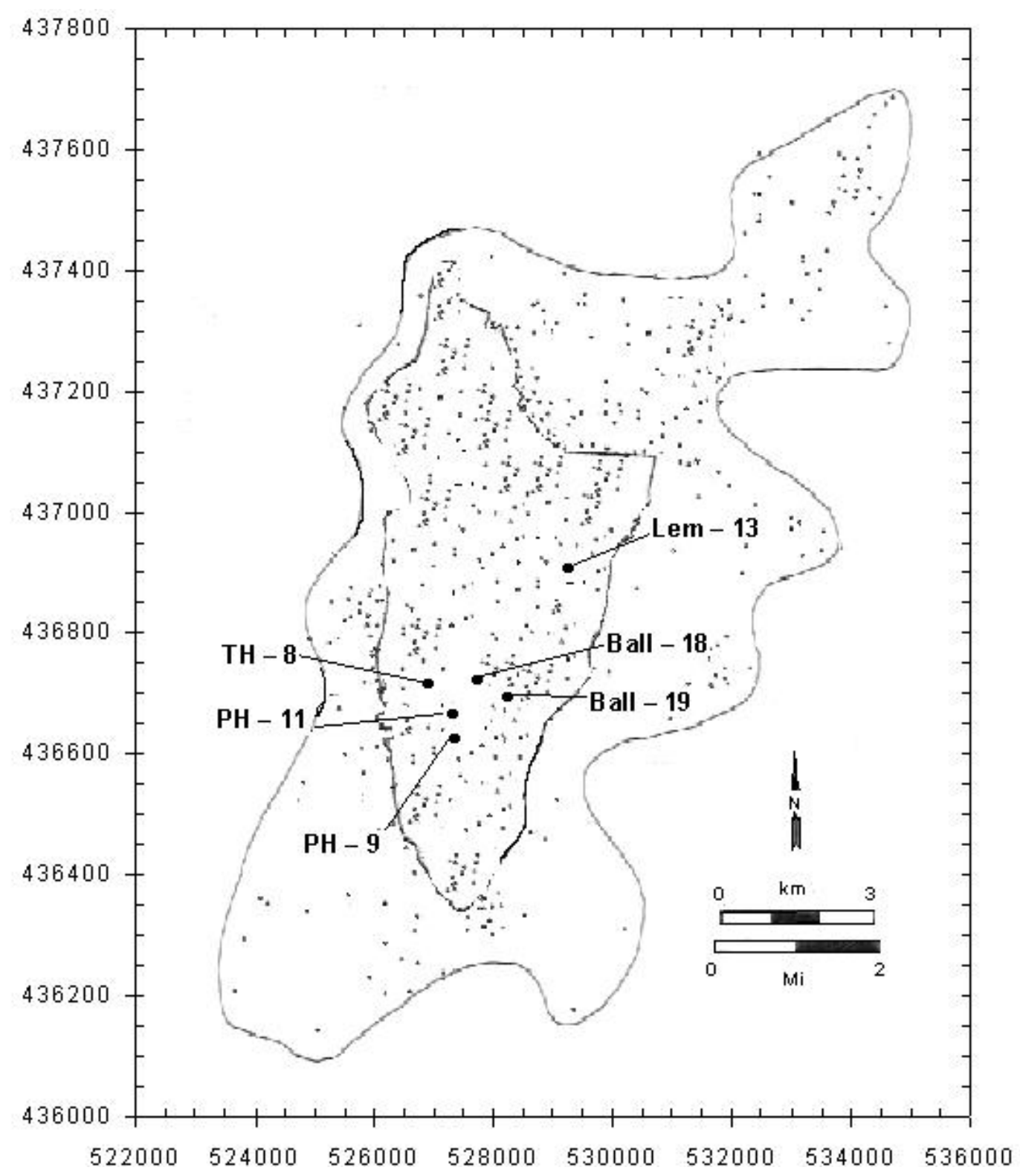

The other three wells namely R -13 , D-14 and L-17 were not used in this study because of incompleteness in their data and their irrelevancies due to very low permeabilities.

For the purpose of simplification, the field has been divided into three units based on porosity and permeability distribution. 
Table 2.1 Core Analysis, Stringtown Oilfield.

\begin{tabular}{|l|l|l|l|l|l|}
\hline Well & Cored & Thickness & Avg. & \multicolumn{2}{|l|}{ Permeability averages mD } \\
\cline { 5 - 6 } & Interval, ft & $\mathbf{f t}$ & porosity, \% & Arithmetic & Geometric \\
\hline Ball-18 & $2988.5-3005.5$ & 17 & 14.7 & 52 & 2.7 \\
\hline Ball-19 & $3086.5-3114.5$ & 28 & 14.9 & 41 & 6.2 \\
\hline Horner-9 & $2891.5-2907.5$ & 16 & 18.2 & 106 & 57 \\
\hline Horner-11 & $3083.7-3100.5$ & 16.8 & 18.8 & 72 & 19 \\
\hline T.Heirs-8 & $2781.5-2796.5$ & 15 & 12.4 & 6.5 & 0.75 \\
\hline
\end{tabular}

\subsubsection{Log Data}

Logs run in the field include Gamma Ray (GR), Density (RHOB), Neutron Porosity and Induction Logs. However, only Log Density was used in this study because of their availability in the studied wells and the readings were every quarter feet. In this study, average log density data for every single foot depth has been taken. So it would be more suitable data to identify the flow units by statistical method.

\subsection{Flow Units}

Flow unit - is a stratigraphically continuous interval of similar reservoir process speed that maintains the geologic framework and characteristics of rock types. In short it can be identified as a zone in a reservoir where the flow of the oil or gas is continuous laterally and vertically and the properties are consistent throughout the 
zone, but do not necessarily coincide with facies boundaries. Therefore, flow units may not be a really contiguous. The hydraulic flow units are influenced mainly by the pore throat geometric properties. Minerology and texture are the controlling parameters in the pore geometry. Minerology is affected by the type, abundance and location of the zone and texture is determined by the grain size, grain shape, sorting and packing method. A different combination of the above discussed geological properties will give a different flow unit. This flow unit will have similar flowing characteristics or fluid transport properties.

\subsection{Techniques for identification of Flow Units ${ }^{9}$}

\subsubsection{From Core Data:}

Core data consists of basically the porosity and permeability of the core sample. These values suffice in the calculation of the above said properties. The hydraulic units can be identified for the values of the Flow Zone Indicator, FZI. Theoretically speaking there should be one FZI value for each hydraulic flow unit. But due to human and non-human inaccuracies and errors there exist some differences in the values of the FZI. Hence we obtain a distribution of FZI values around a mean of these values. Hence the mean value represents the FZI value for that flow unit. When different flow units exist, the overall scatter of the FZI is a superimposition of the individual distributions over the mean values of FZI for each of the flow unit. Identification of each Hydraulic Unit, HU (or therefore each mean FZI) would require careful delineation of the individual groups into each 
constituting $\mathrm{HU}$ by a straight line with the points scattered above and below this line. M.D.Abbaszadeh et al ${ }^{9}$ discussed some of the cluster analysis techniques, which aided in the classification of these groups.

Histogram Analysis, probability analysis and the Ward's analytical algorithm are discussed for cluster analysis in here. However there are several other techniques that can be found in the literature.

\subsubsection{Histogram Approach:}

FZI exhibits a log-normal distribution which can be attributed to the strong relation of FZI with permeability, which in turn has a log-normal Gaussian distribution. A histogram of the FZI with the log-scale on x-axis should show "n" number of normal distributions for " $n$ " number of hydraulic units. The frequency distribution is explained by the equation:

$$
\mathrm{f}=\sum_{i=1}^{N_{H U}} \frac{\omega_{i}}{\sqrt{2 \pi \sigma_{i}^{2}}} \exp \left[-\frac{\left(Z-\overline{z_{i}}\right)^{2}}{2 \sigma_{i}^{2}}\right]
$$

The histogram distinctly separates the flow units when the clusters of data points are distinctly separate from one another. It also provides the FZI values in this case. This method is the easiest and simplest method available. But this has its inherent limitations. It is difficult to separate the overlapped clusters easily and 
reliably. Thus, for most practical purposes this method fails because of the difficulty in delineating the distributions in the transition zones.

\subsubsection{Probability Plot Approach:}

The probability plot is also called a cumulative distribution function plot. It is an integral of the histogram i.e., the probability density function and hence the plot is smoother than the histogram plot. The identification of the flow units is easier because of the ease in identification of individual distributions. This is because of the reduction in the scatter of the data points due to the integration of the probability density function. The cumulative distribution function is given by the equation,

$$
\mathrm{F}=\frac{1}{2}\left[1+\sum_{i=1}^{N_{H U}}\left(\omega_{i} \operatorname{erf}\left(\frac{Z-\overline{z_{i}}}{2 \sigma_{i}^{2}}\right)\right]\right.
$$

The number of straight lines and hence the FZI limiting boundary values for each HU can be obtained from the probability plot of log (FZI). The FZI value representing the hydraulic flow unit is calculated by averaging all the FZI values within the corresponding HU limits. The probability method is lot easier than the histogram method because it is easy to identify straight lines. 


\subsubsection{Ward's Algorithm:}

The ward's algorithm is a cluster analysis technique in which all the available data points are merged one by one until the required number of clusters are obtained. The number of clusters is the input to the ward's algorithm. The advantage of ward's algorithm lies in the manner in which the cluster variances are treated. Clusters are formed to minimize the increase in the within-cluster sums of squares of deviations from their mean. ${ }^{2}$ Each cluster, thus tends to attain a minimum spread around it's mean value, while still maintaining maximum separation from the other clusters. The sum of squared deviations within the group is calculated from the following equation,

$$
\mathbf{W}=\sum_{i=1}^{n_{g}} \sum_{j=1}^{n_{i}}\left(Z_{i j}-Z_{I}\right)^{2}
$$

\subsubsection{HU Prediction Using Log Data ${ }^{8,9}$ :}

Three steps are needed to find the HU distribution in case where log data is available. First, those logs that are sensitive to dynamic flow parameters of porethroat attributes are identified. This is done by either assessing the degree of correlatability of various logs with permeability or FZI, or by performing component analysis. The second step involves construction of a training database which embodies information on the inter-relationship between logs and hydraulic units. The third step utilizes the database information and well log measurements to infer distribution of HUs along the logged wells. The above discussed three steps are discussed below in more detail. 
Amaefule et $\mathrm{al}^{8}$ presented a theoretical methodology to identify the flow units. He defined a concept called Flow Zone indicator, FZI, which classifies the flow units in a reservoir. FZI is defined by the flowing formula

$$
\mathrm{FZI}=\frac{1}{\left(\sqrt{F_{s}}\right) \tau S_{g v}}=\frac{\mathrm{RQI}}{\phi_{Z}}
$$

where Fs is the pore throat shape factor, $\tau$ is the tortuosity, and $\mathrm{S}_{\mathrm{gv}}$ is the effective surface area per unit grain volume. RQI is the reservoir quality index defined below.

$\mathbf{R Q I}=\mathbf{0 . 0 3 1 4} \sqrt{\frac{K}{\phi_{Z}}}$

where $\phi_{\mathrm{Z}}$ is the pore volume to grain volume ratio defined as

$$
\phi_{\mathrm{Z}}=\frac{\phi}{[1-\phi]}
$$

The above parameters were derived from a modified form of the Kozeny-Carmen relation.

\subsubsection{Rank Correlation:}

Spearman's rank correlation technique calculates the degree of correlation between a set of measurements on two variables. Each variable is ranked in a descending or an ascending order. The correlation number between ranks of any two variables is then computed. This procedure is useful since it effectively 
eliminates the well logs with poor correlation numbers. The rank correlation number between ranks of two variables $\mathrm{x}$ and $\mathrm{y}$ is computed from

$$
r_{s}=1-\frac{6 \sum_{i=1}^{n}(X-Y)^{2}}{n\left(n^{2}-1\right)}
$$

Well log measurements and core data such as permeability, RQI, FZI can be used to find the rank correlation for elimination of bad wells. This work does not use this step because of the limited availability of core and log data in the field of study. All the wells with core data were used in the training of the database. Elimination of any of the wells based on this method would have reduced the effectiveness of the training. However this step was discussed as a guideline as to what can be done in case of availability of large amounts of log data and core data.

\subsection{Statistical Zonation Technique:}

A statistical method called Statistical Zonation Technique has been successfully used to detect significant differences between samples. The object in the problem of zonation is to detect the existence of distinct vertical sections or flow units within the permeability profile of each well of the reservoir.

The reservoir zonation technique is a two-step operation. The steps are individually described. First, the set of data at a single well is divided into zones or flow units. These zones are selected so that variation is minimized within the 
zones and maximized between the zones. The equation ${ }^{(6,7)}$ used to zone the data are

$$
\begin{aligned}
& B=\frac{1}{L-1}\left[\sum_{i=1}^{L} m_{i}\left(\overline{k_{i}}-\bar{k} . .\right)^{2}\right] \\
& =\frac{1}{L-1}\left[\sum_{i=1}^{L} \frac{\left(\sum_{j=1}^{m_{i}} k_{i j}\right)^{2}}{m_{i}}-\frac{\left(\sum_{i=1}^{L} \sum_{j=1}^{m_{i}} k_{i j}\right)^{2}}{N}\right] \\
& W=\frac{1}{N-L}\left[\sum_{i=1}^{L} m_{i} \sum_{j=1}^{m_{i}}\left(k_{i j}-\bar{k}_{i .}\right)^{2}\right] \\
& =\frac{1}{N-L}\left[\sum_{i=1}^{L} \sum_{j=1}^{m_{i}} k_{i j}{ }^{2}-\sum_{i=1}^{L} \frac{\left(\sum_{j=1}^{m_{i}} k_{i j}\right)^{2}}{m_{i}}\right] \\
& R=\frac{B-W}{B}
\end{aligned}
$$

The first step in the calculation is to divide the log and core data, in their original order of depth, into all possible conditions of two zones. Equation 1 and 2, and then equation 3, are used to calculate for each of these possible two zone combinations. Equation 3, the index of zonation, is the criterion used to denote the best division. This index, which ranges between 0.0 to1.0, indicates how closely 
the division corresponds to homogeneous zones. The closer the index is to 1.0, the more homogeneous the zones. Therefore, the larger index denotes the best division into two zones and is retained for comparison with other indices.

After the two-zone combination is determined, the data are divided into all possible three combinations, with the previous two-zone point of division being one of the (two) points of division into three zones. Eqs. 1, 2 and 3 are again computed for each of three divisions, and the best division is again defined by the maximum index.

Next, the data are divided into all possible four-zone combinations. The previous points of division are again retained as two of the (three) points of division into four zones. In this manner, the set of permeability data can be divided into any number of zones up to the number of data.

At each extension of the number of zones in a well, the new index is compared with the previous index. The division into additional zones continues until two successive indices show no significant increases. In our study with reservoir permeability data have indicated that the difference between two successive indices is not significant if it is less than 0.001 .

After individual wells are identified with different flow units, the second portion of the calculation is undertaken. This part correlates the flow units from well to 
well throughout the reservoir to aid the engineer in determining continuity of the strata. The correlation is based on a statistical comparison of the difference of means of two zones in adjoining wells with the difference that could be expected from variation of measurements within the flow unit. If the difference of means is less than or equal to that expected from individual data variation, the flow unit represented by the means is considered to correlate and, by inference, be continuous. 


\section{CHAPTER THREE}

\section{OBJECTIVE}

Based on the literature review it has been observed that core permeability data has played an important role in characterizing a reservoir rather that log data. But core permeability data is not usually available for all wells throughout the reservoir. The main objectives of this study are to

$>$ Perform statistical calculation to identify flow unit from original core permeability data

$>$ Developed a model to predict permeability from Log Density and limited core permeability data.

$>$ Identify flow unit from the predicted permeability.

Validate the model by comparing predicted flow units against original flow units.

$>$ Perform statistical correlation between the flow units throughout the reservoir. 


\section{CHAPTER FOUR}

\section{METHODOLOGY}

Although there are many techniques to characterize a reservoir, statistical technique is very important to identify and describe naturally occurring flow units in a reservoir and to correlate these flow units from well to well. The technique is particularly useful in describing a reservoir where cross flow between adjacent strata is important in determining reservoir behavior. Permeabilities play an important role to determine flow units in a reservoir. Due to the sheer volume, it is always necessary to group data and to use an average value to represent a number of measurements. Flow unit computation is derived from the permeability data. But permeability at all depth level, at all wells is not available and not practical to measure. Hence, this research aims to economically predict permeability from available density and limited core data. The predicted permeability is used to define correlation of flow units among adjacent wells.

\subsection{Development of Permeability prediction model:}

Obtaining permeability data through core analysis are expensive and time consuming. Although permeability plays an important role to characterize a reservoir, it is not available for all wells in a reservoir. So in this research a model is being developed to predict permeability at definite depth of different wells from the known permeability of other wells. The objective of this research is to develop 
a model from known data, which is computationally less expensive, simple and easily.

In lieu of a definite mathematical relationship of permeability with any measured parameter of the wells, this research aimed at developing statistical model. Preliminary observation suggested that a linear regression model might be a simple but accurate enough solution. A regression model is a formal means of expressing the two essential ingredients of a statistical relation:

1. A tendency of the dependent variable $\mathrm{Y}$ to vary with the independent variable or variables in a systematic fashion.

2. A scattering of observations around the curve of statistical relationship.

These two characteristics are embodied in a regression model by postulating that:

1. In the population of observations associated with the sampled process, there is a probability distribution of $\mathrm{Y}$ for each level of $\mathrm{X}$.

2. The means of these probability distributions vary in some systematic fashion with X.

\subsubsection{Selection of Independent Variable:}

Since data must be reduced to manageable proportions whenever we contrast models, only a limited number of independent or predictor variables can - or should - be included in a regression model for any situation of interest. A central problem therefore is that of choosing, for a regression model, a set of independent 
variables which is "good" in some sense for the purposes of analysis. A major consideration in making this choice is the extent to which a chosen variable contributes to reducing the remaining variation in $\mathrm{Y}$ after allowance is made for the contributions of other independent variables that have tentatively been included in the regression model. Other considerations include the importance of the variable as a casual agent in the process under analysis; the degree to which observations on variable can be obtained more accurately, or quickly, or economically than on competing variables; and the degree to which the variable can be preset by management. Predictor variable must be readily available and have sufficient causal effect on the predicted variable. In the literature review it has been observed that density has an impact on reservoir permeability. Log density, gamma ray and some other data are also readily available. Hence, log density data is used as independent variable in this model.

\subsubsection{Functional Form of Model}

Though it is clear that density is the most influential factor in determining permeability, but exact form of the relationship is unknown. To have a better understanding some measured data points are plotted in Figure 4.1. 


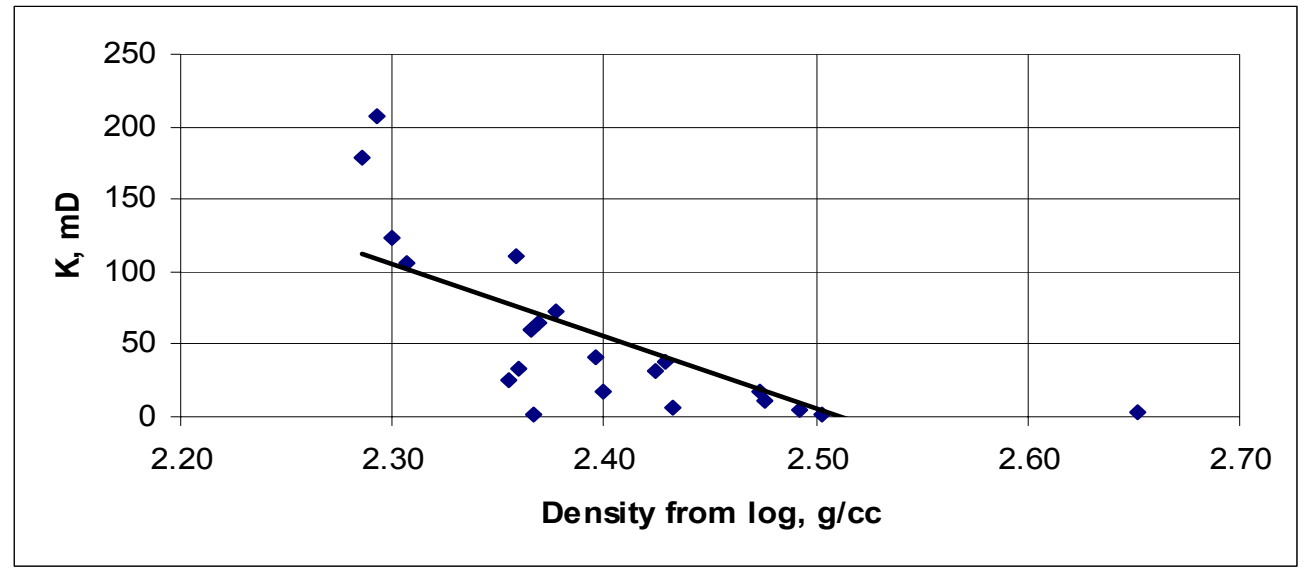

Figure 4.1: Plot of Density Vs Permeability data taken from well F. R. Ball 19

The scattered plot shows lack of linear relationship between log density and permeability. The general remedies of non-linearity in regression are ${ }^{34}$ :

1. direct approach: changes the model according to the nature of the relationship, for example a quadratic or polynomial relationship may be tried. Or

2. transformation approach: uses transformation to linearize.

This research uses transformation $\mathrm{Y}=\log \mathrm{K}$. The plot of the transformed values for measured data is presented in Figure 4.2. 


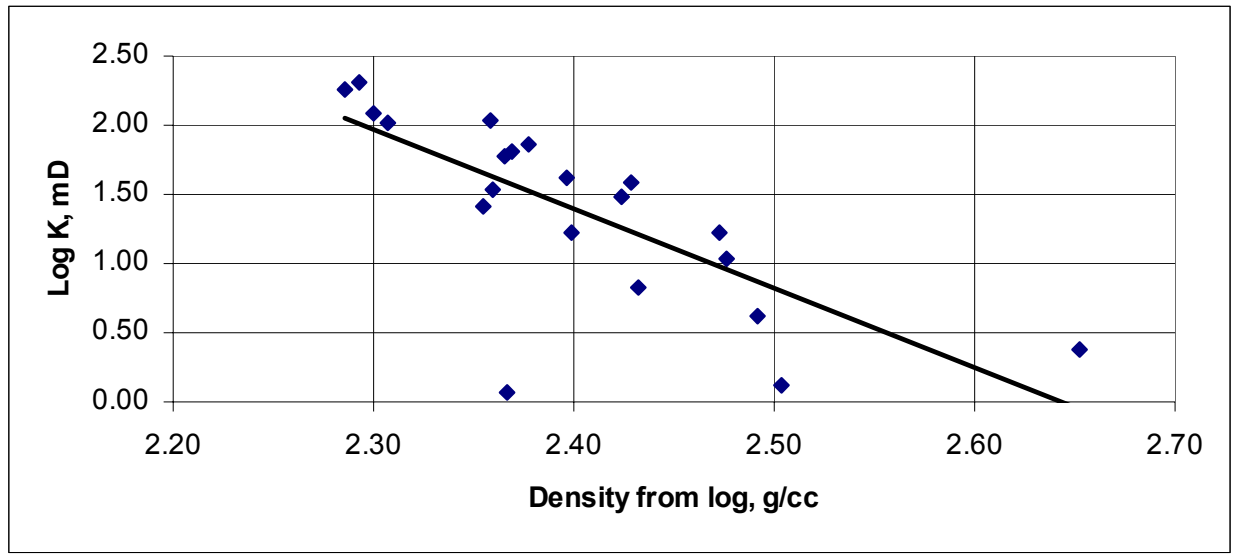

Figure 4.2: Plot of Density Vs Logarithmic K from well F. R. Ball 19

The plot clearly shows much better linear relationship might exist between density, D and logarithmic transformation of permeability, K. So the proposed prediction model is:

$$
\log K=\beta_{0}+\beta_{1} D
$$

\subsubsection{Scope and assumption:}

The model is only valid for the reservoir from which development data set is obtained. The model assumes that reasonable number of permeability data is available for adjacent wells at various depths. Permeability values below $1.0 \mathrm{mD}$ should not be considered for development of the model since they tend to decrease the correlation between core permeability and log density. In model development, it is assumed that the average of the measured permeability over a 
small distance is a reliable representation of the permeability at the mid-point of that measured distance.

\subsubsection{Model Validation:}

The log density and core permeability data from six wells were available. The log density for each of those six wells were measured in $1 / 4$ " interval. Table 4.1 below shows the number of permeability data available for six wells.

\begin{tabular}{|c|c|c|c|}
\hline $\begin{array}{c}\text { Number of } \\
\text { Well Data Set }\end{array}$ & Well Name & $\begin{array}{c}\text { Original number of } \\
\text { permeability data }\end{array}$ & Depth, ft \\
\hline 1 & F.R. Ball 18 & 13 & $2990.75-3007.75$ \\
\hline 2 & F.R. Ball 19 & 21 & $3086.25-3113.75$ \\
\hline 3 & Lemasters 13 & 4 & $3048.75-3052.75$ \\
\hline 4 & T. Heirs 8 & 7 & $2791.50-2797.50$ \\
\hline 5 & P. Horner 9 & 15 & $2891.75-2905.75$ \\
\hline 6 & P. Horner 11 & 8 & $3048.50-3093.25$ \\
\hline
\end{tabular}

Table 4.1: Number of available core permeability data for six cored wells.

For this data set, six different tests were performed to validate the proposed linear model. In each test, data set is partitioned into two different sets. Set 1 consists of measured data from 5 wells, which is used to develop the regression model parameters. The regression equation is then used to predict and compare the permeability of the remaining well, which is in set 2 . The table below shows the description of six different tests: 


\begin{tabular}{|c|c|c|}
\hline Test Number & Development Data Set & Validation Data Set \\
\hline Test 1 & $2,3,4,5,6$ & 1 \\
\hline Test 2 & $1,3,4,5,6$ & 2 \\
\hline Test 3 & $1,2,4,5,6$ & 3 \\
\hline Test 4 & $1,2,3,5,6$ & 4 \\
\hline Test 5 & $1,2,3,4,6$ & 5 \\
\hline Test 6 & $1,2,3,4,5$ & 6 \\
\hline
\end{tabular}

Table 4.2: List of six different tests performed.

The predicted permeability values are compared against the original values and presented in Appendix B. The result demonstrates that the model is adequate to predict permeability in the adjacent wells.

\subsection{Flow Units determination of individual Wells}

Different mathematical and statistical approaches for determining flow unit are discussed in Chapter Two. Hence all those techniques are good to identify the flow units, only statistical technique has been selected to identify flow unit from core permeability and predicted permeability data. Statistical technique is general and can be used to correlate any reservoir property or related data, such as the information contained in well logs.

The computational procedure is illustrated in the following example.

To illustrate the statistical calculation, measured core permeability data from the Data Set 1 (well F. R. Ball 18) has been selected. Table D-1 in Appendix D 
illustrates the division of the data into two zones; the asterisk marks are the point of division in Table D-1.

Eqs. 1, 2 and 3 are computed for each division into two zones and tabulated in the columns labeled B, W and R. Note that any negative values in R are replaced by zero in order to confirm to the definition of R. For example, the first line in Table D-1 is as follows.

Variance between zones, $B=\frac{1}{L-1}\left[\sum_{i=1}^{L} m_{i}\left(\bar{k}_{i}-\bar{k}_{. .}\right)^{2}\right]$

$$
=6473.23
$$

The pooled variance within zones, $W=\frac{1}{N-L}\left[\sum_{i=1}^{L} m_{i} \sum_{j=1}^{m_{i}}\left(k_{i j}-\bar{k}_{i .}\right)^{2}\right]$

$$
=9040.53
$$

The zonation index, $R=\frac{B-W}{B}$

$$
=-0.379
$$

Which is replaced by zero: and the other lines are computed in the same way. A sample calculation for well F R Ball 18 has been shown in Appendix C.

The best division into two zones occurs after the permeability value $137 \mathrm{mD}$ at the depth $2999.75 \mathrm{ft}$ as shown in Table D-1. 
Since the original permeability data of well F. R. Ball 18 has already separated into two groups, the problem is now that of separating either Group 1 or Group 2 into two additional groups. Table D-2 shows details of tabulated results by performing equation 1,2 and 3 .

The second point of division (the first was after the permeability value of 137 in Table D 1) occurs after the permeability value 20 at Group 1 data series, and defines our total data as a set of three groups, or flow units. It has been observed that the zonation index, $\mathrm{R}$ value is decreasing in the second group data, so it could be decided that there is no more possible group in the second group. The results of the calculations for the division of the data into four zones are also given in Table D-3 which indicate that the largest four-zone index, 0.987 is similar than the largest three-zone index of 0.987 . Therefore, the well is better described as three flow units or there are three different flow units in the well F. R. Ball 18.

The other wells were divided into flow units in the same manner using core permeability and predicted permeability data. The final results of flow unit determination are tabulated in the Appendix D and E.

\subsection{Correlation of flow units between adjacent Wells:}

After individual wells are divided into different flow units, the second portion of the calculation is undertaken for each kind of data individually that has been used to characterize the reservoir. This part correlates the flow units from well to well throughout the reservoir to aid the engineer in determining continuity of the strata. 
The correlation is based on a statistical comparison of the difference of means of data of two flow units in adjoining wells with the difference that could be expected from variation of measurements within the flow units. If the difference of means is less than or equal to that expected from individual data variation, the flow units represented by the means are considered to correlate and, be continuous.

The mathematical statement is given by Eq. 4 :

$$
\left(\overline{k_{h}}-\overline{k_{i}}\right)>\sqrt{\frac{1}{2}\left(\frac{1}{n_{h}}+\frac{1}{n_{i}}\right)} S Z_{(V, P)}
$$

Harter $^{7}$ provides a table of $Z$ - values.

If the left side of Eq. 4 is larger than the right side, the flow units represented by the two means are considered, on the basis of statistics, to be different. However, if the left side of Eq. 4 is smaller than the right side, the flow units correlate and can be considered to be continuous. Statistically, this is all that could be decided on the basis of reservoir data.

From the Tables in Appendix D and E, Eq. 4 has been applied to the zone data. A sample calculation has been established in Appendix C Part 2 for original flow units from six cored wells. The following steps are suggested as a conventional and efficient manner of applying Eq. 4. 
(1) Rank well-zone means in order of decreasing magnitude of permeability, like as Table C.1.

(2) Calculate Eq. 2 using all permeability data in the entire reservoir.

(3) Calculate the standard deviation from Step 2.

(4) Select the z-values ${ }^{7}$ for a 99 percent probability level $\left(Z_{v, p}\right)$

(5). Multiply the Z-values in Step 4 by the standard deviation in Step 3, e. $g ., F_{p}{ }_{p}=S Z_{v, p}$

(6). Test the significant differences among well - flow unit means. First the largest mean is compared with each of the smaller means.

Finally the means can be distinguished as separate groups, which are not significantly different. 


\section{CHAPTER FIVE}

\section{Results \& Discussions}

This research has developed a predictive model for flow unit correlation based on well log data and limited core data. The model is validated with the data set available from Stringtown Oil Field, WV. The log density and core permeability data was available from six different adjacent wells. The model is validated six times. Each time dividing the available data into two sets: Set I: development data set which consists of data from 5 wells and Set II: is the validation data set which consists of the data from the remaining well. The resulting six tests are described in Table 4.2. In this chapter, the predicted flow strata and flow strata from measured data for all six tests are presented and analyzed.

\subsection{Discussion of results for Test 1}

In this case data is divided into following two data sets:

Set I: Development Data Set (F.R.Ball 19, Lemasters 13, T.Heirs 8, P.Horner 9 and P.Horner 11)

Set II: Validation Data Set (F.R.Ball 18).

Based on the measured data in Set I, the linear model for permeability prediction is developed. The linear relationship of logarithmic permeability and log density is developed as discussed in Section 4.1.2. The model is given by:

$\log K=16.62-6.3261 X$, where $X$ is the density from logs of the well. 
Based on this model, the permeability for the well in Set II (Ball 18) is predicted.

Figure 5.1 (a) depicts the comparison of the predicted permeability values and measured values at different depths of the well. Using this predicted permeability and the technique described in Section 4.2 flow units for the well Ball 18 are computed. The predicted flow units are compared with the flow units obtained by using measured permeability (data Set II) in Figure 5.1 (b).
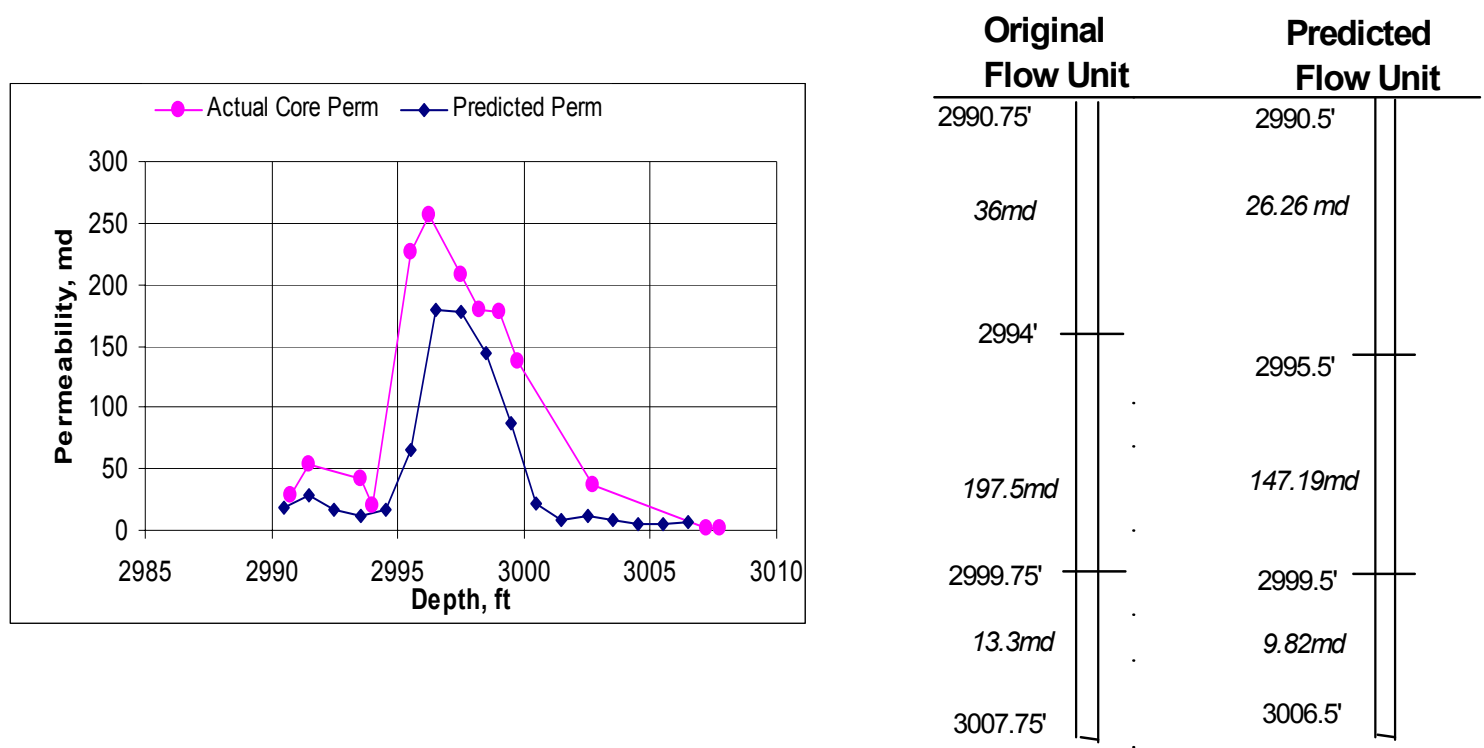

Figure 5.1(a) Actual and measured permeability for $F$. R. Ball 18
Figure 5.1(b) Mean permeability in actual and predicted flow units for F. R. Ball 18

Figure 5.1 (a) shows that the predicted permeability and measured permeability at different depths of the well are pretty much in agreement. Though the Figure 5.1 (b) shows that the predicted mean permeability values are off from the measured 
mean values but it is clear that the high permeability and low permeability zones are almost unaltered. It can be noted that, for all practical purposes the zonal divisions at correct depth is much more significant than the absolute permeability values at a certain depth. Hence it can be concluded that the model serves the purpose by correctly predicting the high permeability and low permeability zones for the well Ball 18.

The ultimate objective is to predict the flow unit strata of the reservoir through unknown wells given that the flow strata for the adjacent wells are known. Using the technique described in Section 4.3 the correlation of flow units among adjacent wells are determined. The flow strata through the wells in data Set I is depicted in Figure 5.2. Hence the depth of flow strata of the wells has been shown based on sub sea level rather than their original individual depth. Figure 5.3 represents the flow unit strata when Ball 18 with predicted permeability is included into the computation. On the other hand, if the measured permeability data (Set II) for Ball 18 is considered, the flow unit strata are presented by Figure 5.4 . 


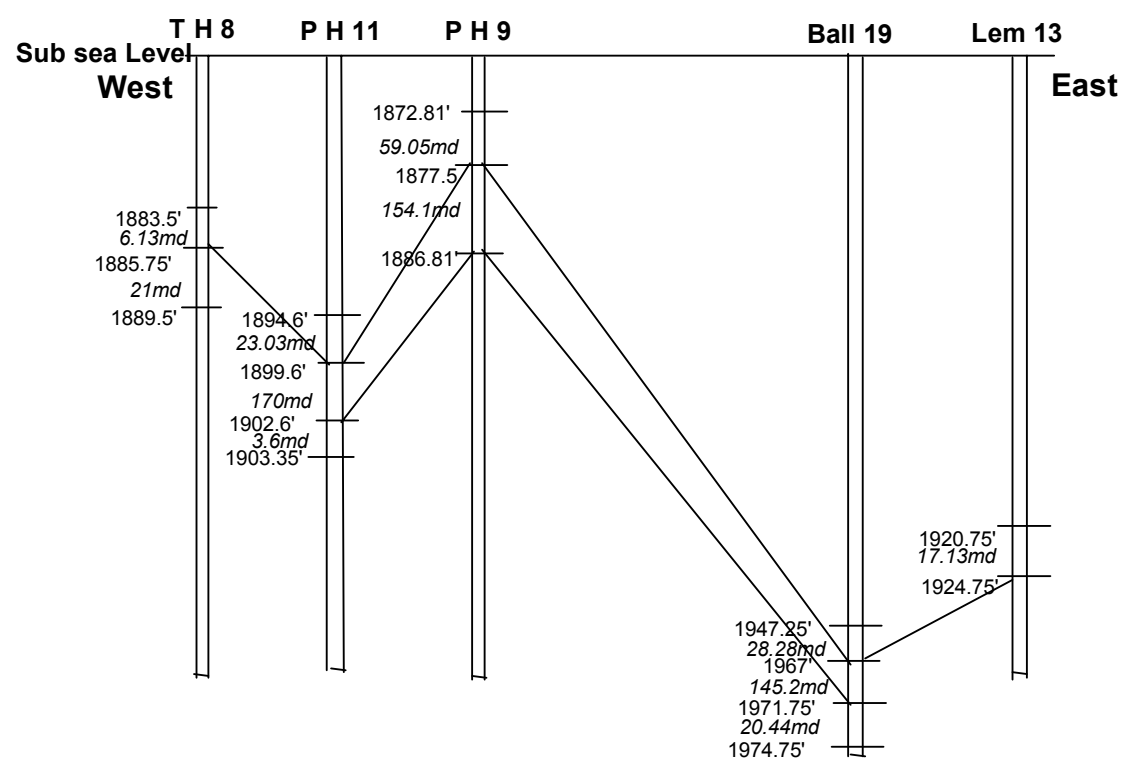

Figure 5.2: Correlation of flow units for Development Data Set in Test 1

(except Ball 18)

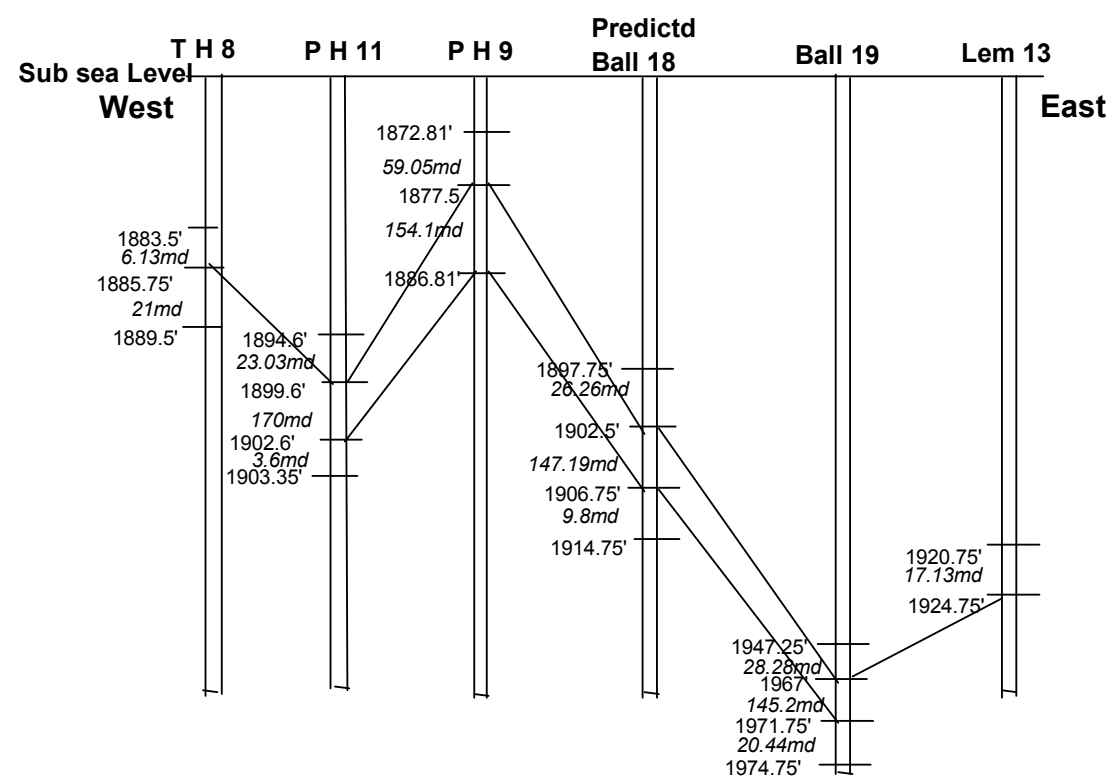

Figure 5.3: Correlation of flow units for Development Data Set in Test 1 with predicted flow unit of Ball 18. 


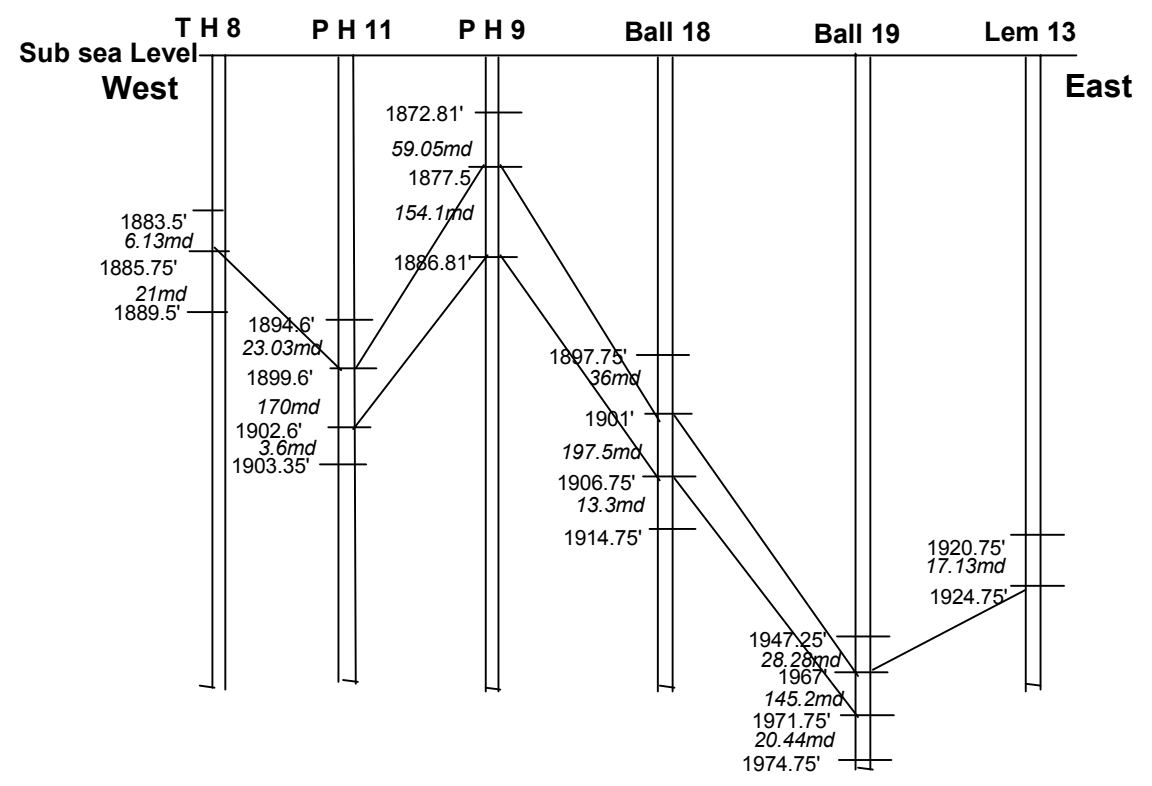

Figure 5.4: Correlation of flow units from measured permeability data for six cored wells.

An examination of Figure 5.3 clearly shows that the high permeability zone is a continuous stratum over the adjacent wells. This fact is supported by Figure 5.4. The predicted strata (Figure 5.3) and the actual strata both have divided the reservoir in two low permeability zones separated by on high permeability zone. The predicted zonal depths for the unknown well (Ball 18) given by Figure 5.3 are comparable with the actual zonal depths in Figure 5.4. The predicted flow unit strata shows that well TH8 does not have a high permeability zone. The plot for actual flow unit correlation in Figure 5.4 supports the prediction. 


\subsection{Discussion of results for Test 2}

In this case data is divided into following two data sets:

Set I: Development Data Set (F.R.Ball 18, Lemasters 13, T.Heirs 8, P.Horner 9 and P.Horner 11)

Set II: Validation Data Set (F.R.. Ball 19).

The permeability prediction model is given by:

$\log K=18.415-7.0622 X$, where $X$ is the $\log$ density of the well.

Figure 5.5 (a) depicts the comparison of the predicted permeability values and measured values at different depths of the well. The predicted flow units are compared with the flow units obtained by using measured permeability (data Set II) in Figure 5.5 (b).
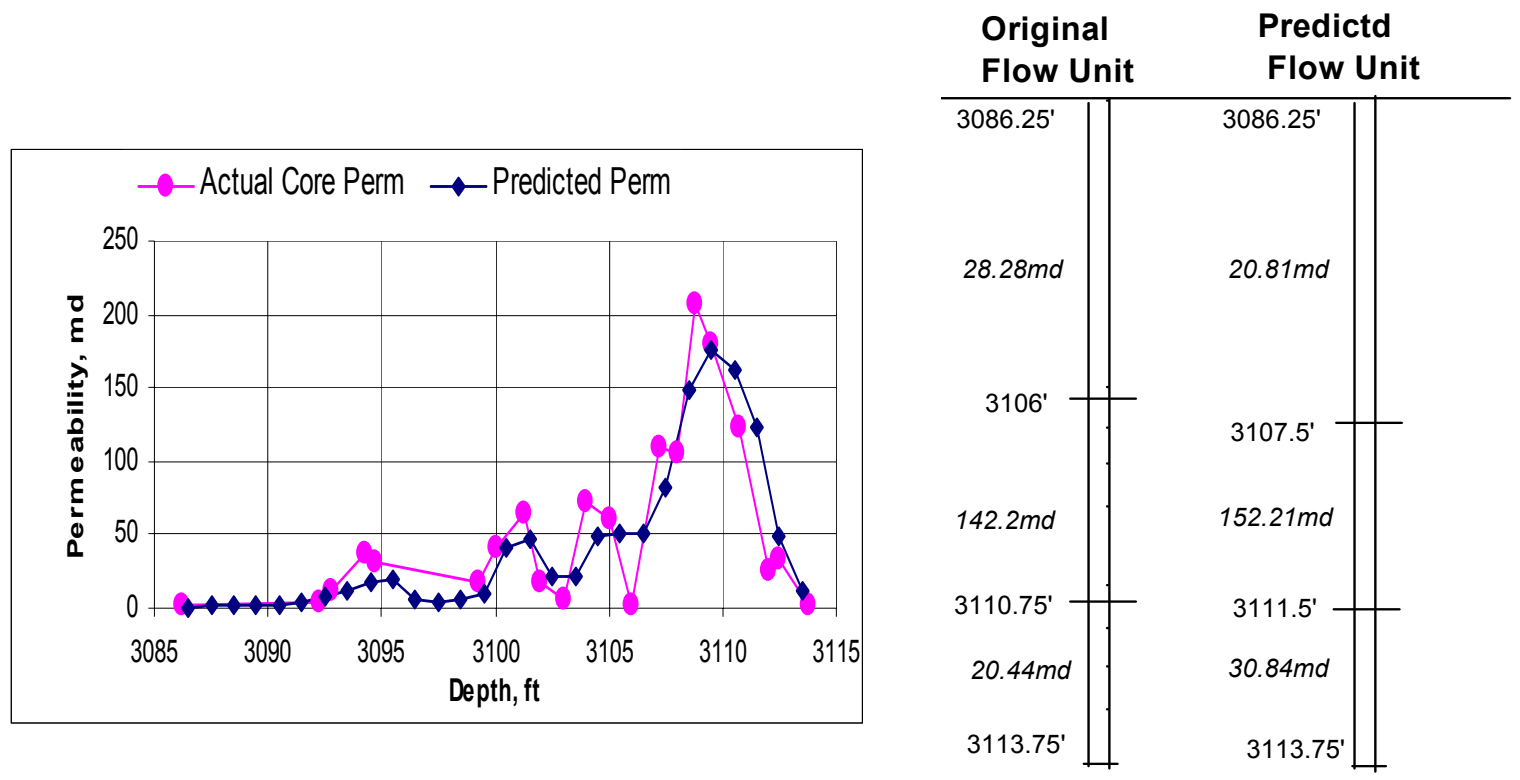

Figure 5.5(a) Actual and measured

Figure 5.5(b) Actual and predicted units for F. R. Ball 19 
The Figure 5.5 verifies that based on predicted permeability, flow unit zones for the well Ball 19 is correctly presumed.

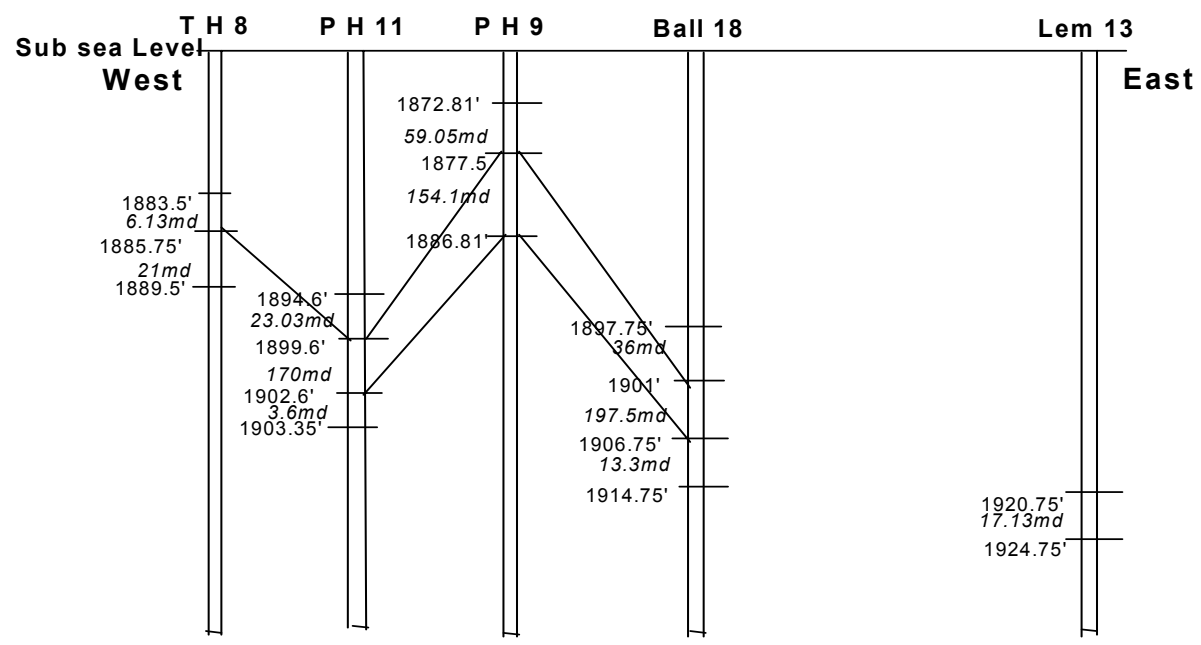

Figure 5.6: Correlation of flow units for Development Data Set in Test 2 (except Ball 19) 


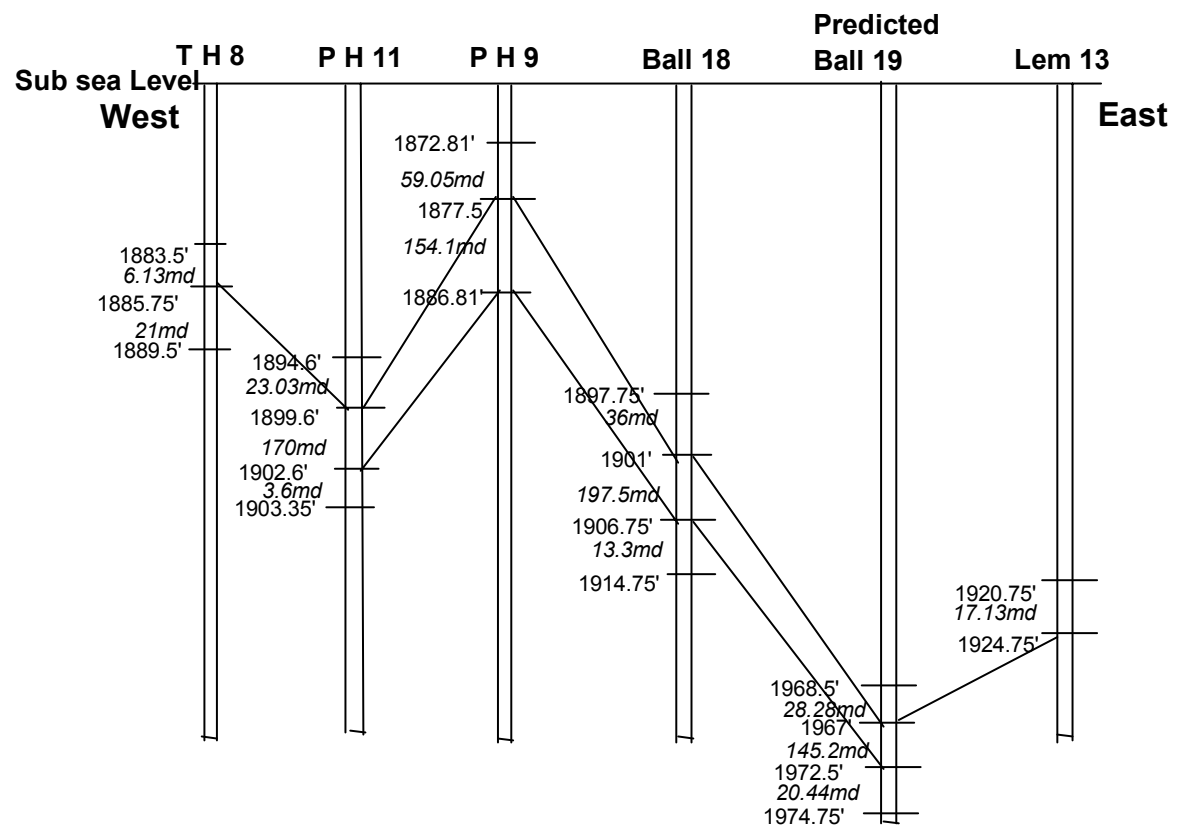

Figure 5.7: Correlation of flow units for Development Data Set in Test 2 with predicted flow unit of Ball 19.

The flow strata through the wells in data Set I is depicted in Figure 5.6. Figure 5.7 represents the flow unit strata when Ball 19 with predicted permeability is included into the computation. A comparison of Figure 5.7 and Figure 5.4 (flow unit strata using measured permeability data for all wells including Ball 19) shows that the predicted flow zones are accurate enough for engineering purposes.

\subsection{Discussion of results for Test 3}

In this case data is divided into following two data sets:

Set I: Development Data set (F.R.Ball 18 F.R.Ball 19, T.Heirs 8, P. Horner 9 and P.Horner 11) 
Set II: Validation Data set (Lemasters 13).

The permeability prediction model is given by:

\section{$\log K=17.013-6.479 X$}

Where, $\mathrm{X}$ is the log density of the well.

Figure 5.8 (a) depicts the comparison of the predicted permeability values and measured values at different depths of the well. The predicted flow units are compared with the flow units obtained by using measured permeability (data Set II) in Figure 5.8 (b).
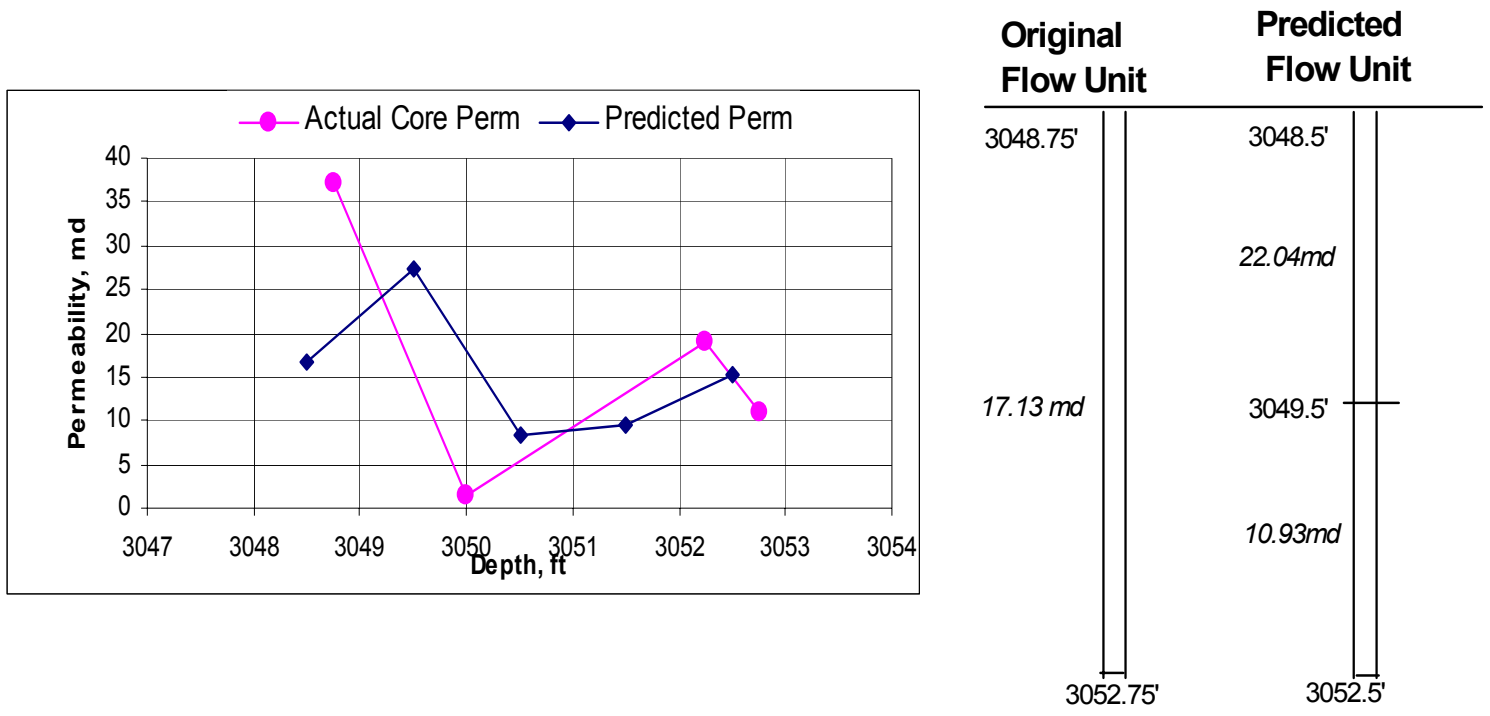

\section{Figure 5.8 (a) Actual and measured permeability for Lemasters 13} flow units for Lemasters 13

The measured permeability data for Lemasters 13 at different depths were either of very low values or below $1.0 \mathrm{mD}$. According to model assumptions (Section 4.2) the permeability data below $1.0 \mathrm{mD}$ were ignored. As a result of eliminating values less than $1.0 \mathrm{mD}$, only four data points over a depth of five feet were 
available. The flow unit computations based on the few actual data points have forced the whole well into a single flow zone. Figure 5.8 (b) shows that the predicted flow unit has divided the well into two statistically significant flow zones. Again, careful examination shows that the mean permeability values of those two zones are not that different. Hence, it can be concluded that irrespective of the predicted flow zones engineering judgment is necessary.

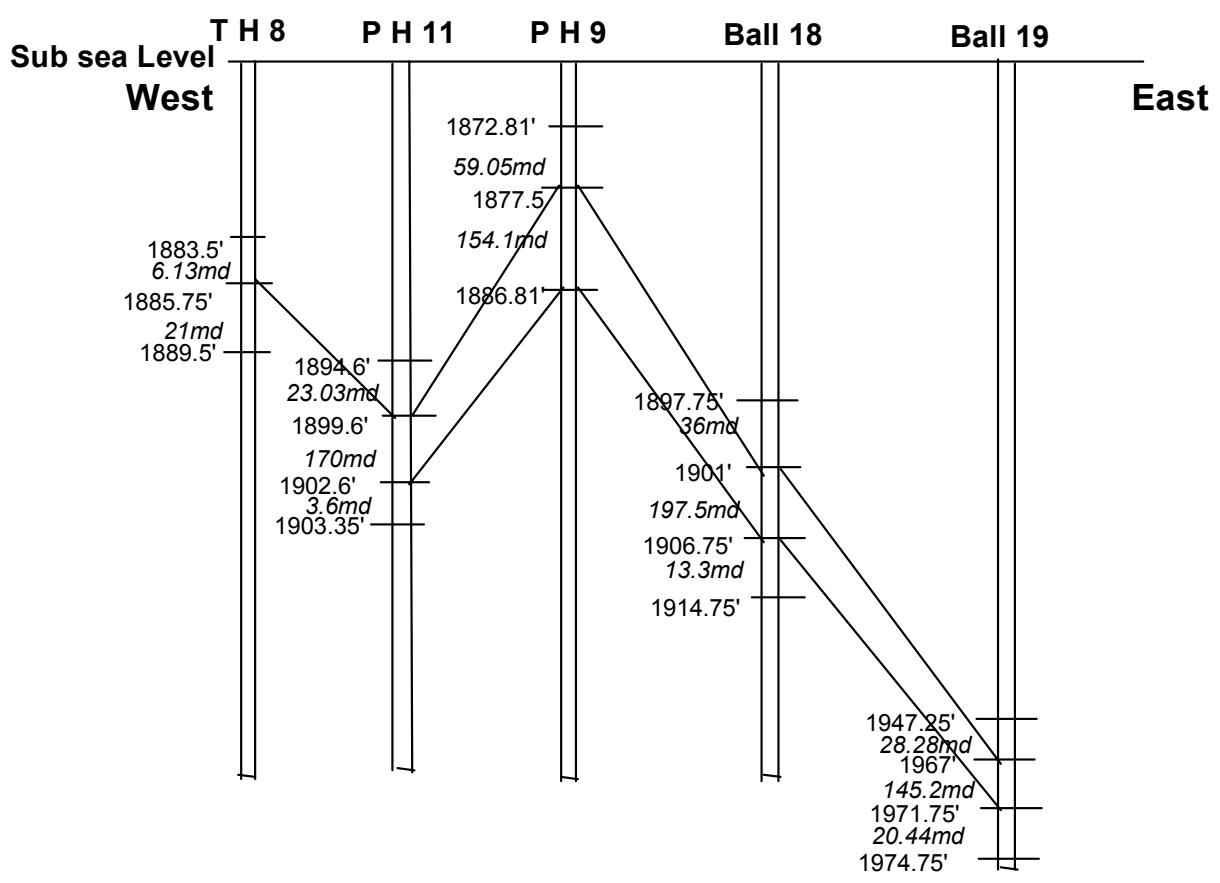

Figure 5.9: Correlation of flow units for Development Data Set in Test 3 (except Lemasters 13) 


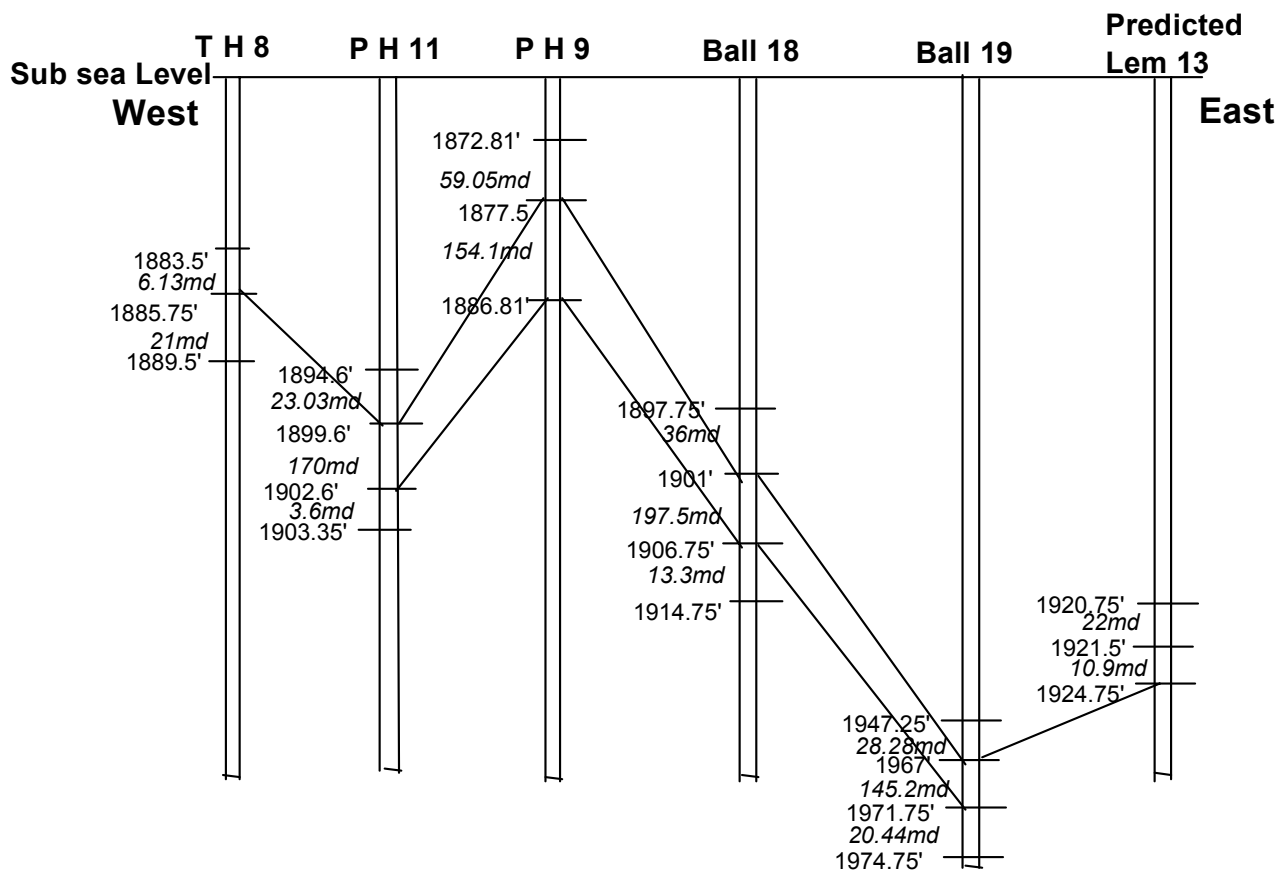

Figure 5.10: Correlation of flow units for Development Data Set in Test 3 with predicted flow unit of Lemasters 13.

The flow strata through the wells in data Set I is depicted in Figure 5.9. Figure 5.10 represents the flow unit strata when Lemasters 13 with predicted permeability is included into the computation. A comparison of Figure 5.10 and Figure 5.4 (flow unit strata using measured permeability data for all wells including Lemasters 13) shows that the predicted flow zones are in agreement. Though the predicted model divided Lemasters 13 in two separate flow zones with both of them is in low permeability zone the actual correlation of flow zones (Figure 5.4) shows that Lemasters 13 does not have any high permeability zone. 


\subsection{Discussion of results for Test 4}

In this case data is divided into following two data sets:

Set I: Development Data Set (F.R.Ball18, F.R.Ball 19, Lemasters 13, P.Horner 9 and P.Horner 11)

Set II: Validation Data Set (T. Heirs 8).

The permeability prediction model is given by:

$$
\log K=17.353-6.607 X \text {, }
$$

where $\mathrm{X}$ is the log density of the well.

Figure 5.11 (a) depicts the comparison of the predicted permeability values and measured values at different depths of the well. The predicted flow units are compared with the flow units obtained by using measured permeability (data Set II) in Figure 5.11 (b).
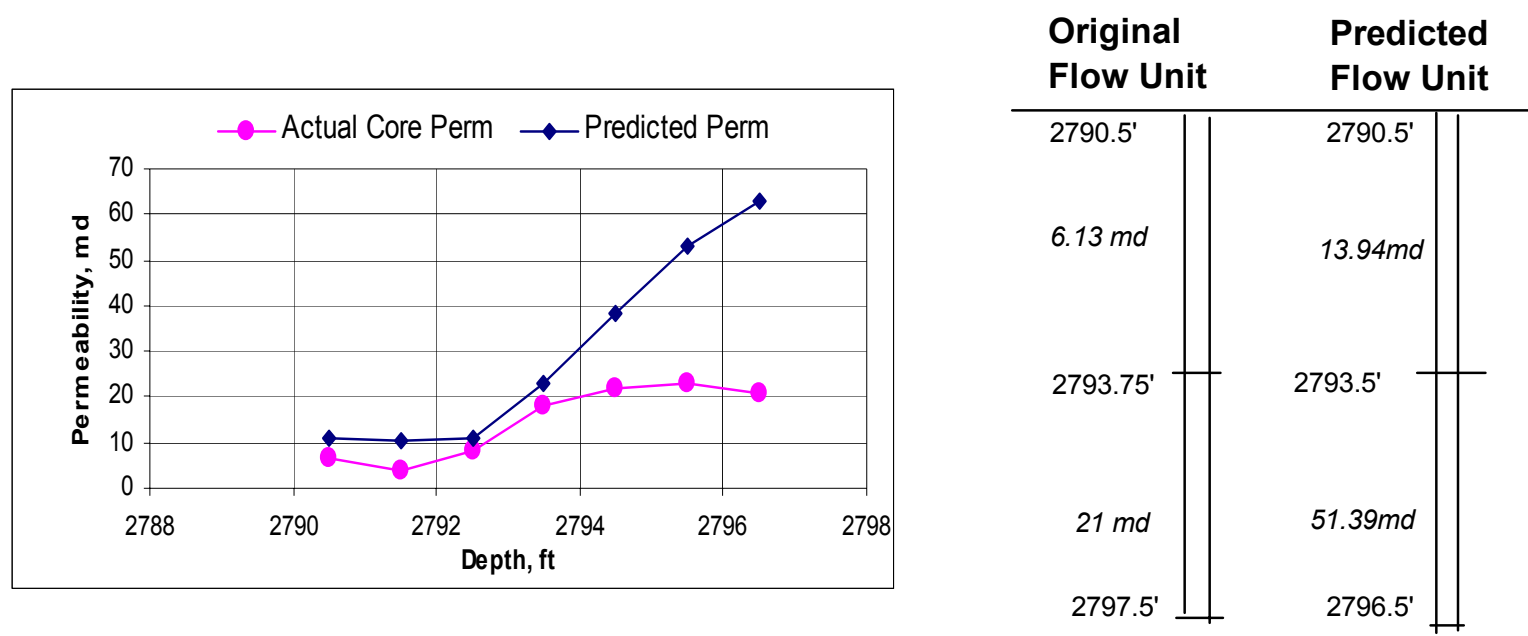

permeability for T. Heirs 8

Figure 5.11 (b) Actual and predicted flow units for T. Heirs 8 
The Figure 5.11 verifies that flow unit zones for the well T. Heirs 8 is correctly identified based on predicted permeability.

The flow strata through the wells in data Set $\mathrm{I}$ is depicted in Figure 5.12. Figure 5.13 represents the flow unit strata when T. Heirs 8 with predicted permeability is included into the computation. A comparison of Figure 5.13 and Figure 5.4 (flow unit strata using measured permeability data for all wells including T. Heirs 8) shows that the predicted flow zones are accurate enough for engineering purposes.

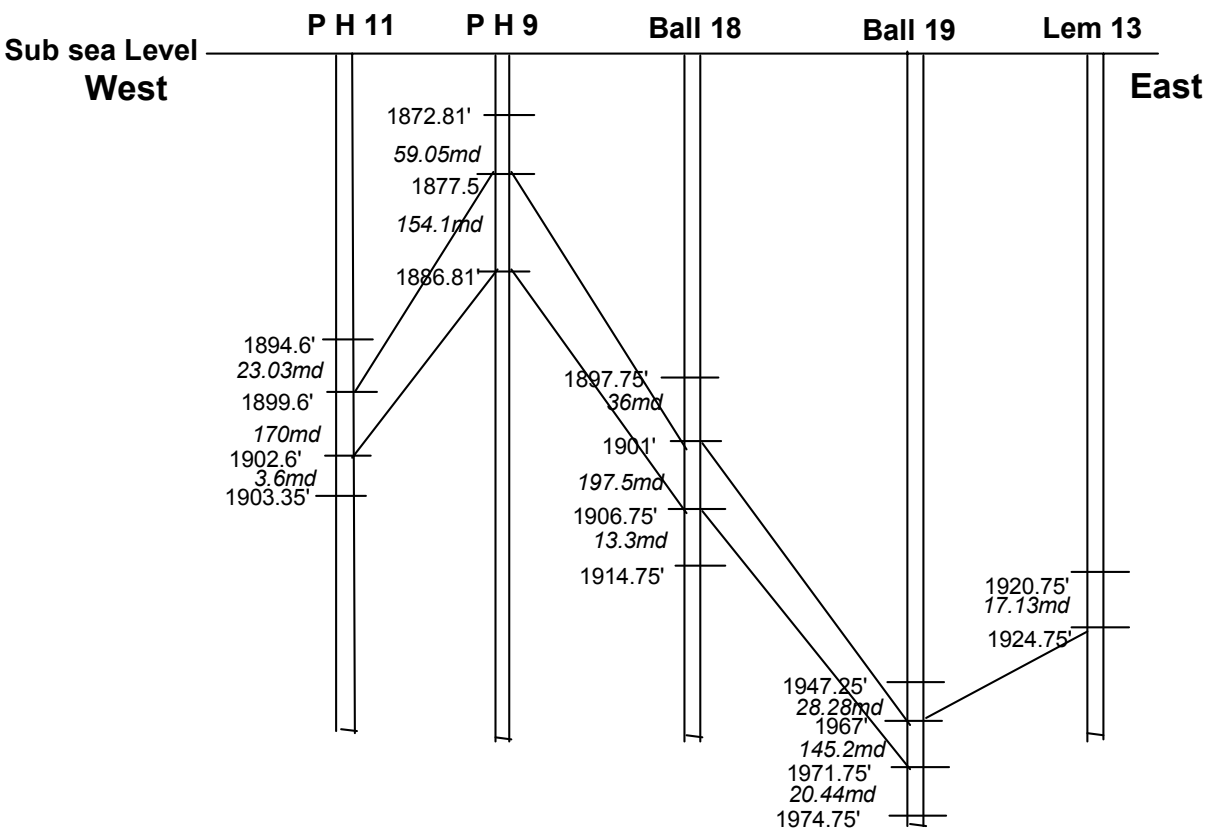

Figure 5.12: Correlation of flow units for Development Data Set in Test 4 (except T. Heirs 8) 


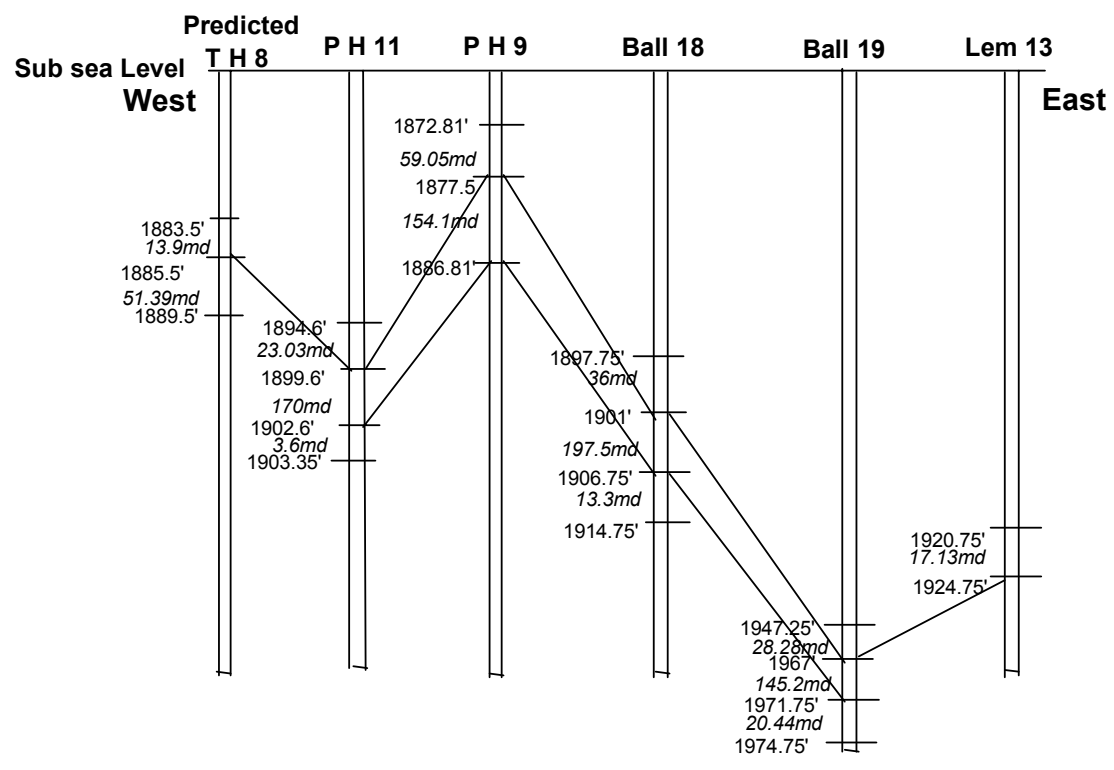

Figure 5.13: Correlation of flow units for Development Data Set in Test 4 with predicted flow unit of T. Heirs 8 .

\subsection{Discussion of results for Test 5}

In this case data is divided into following two data sets:

Set I: Development Data Set (F.R.Ball 18, F.R.Ball 19 Lemasters 13, T.Heirs 8, and P.Horner 11)

Set II: Validation Data Set (P.Horner 9).

The permeability prediction model is given by:

$$
\log K=18.018-6.934 X
$$

where $\mathrm{X}$ is the $\log$ density of the well. 
Figure 5.14 (a) depicts the comparison of the predicted permeability values and measured values at different depths of the well. The predicted flow units are compared with the flow units obtained by using measured permeability (data Set II) in Figure 5.14 (b).

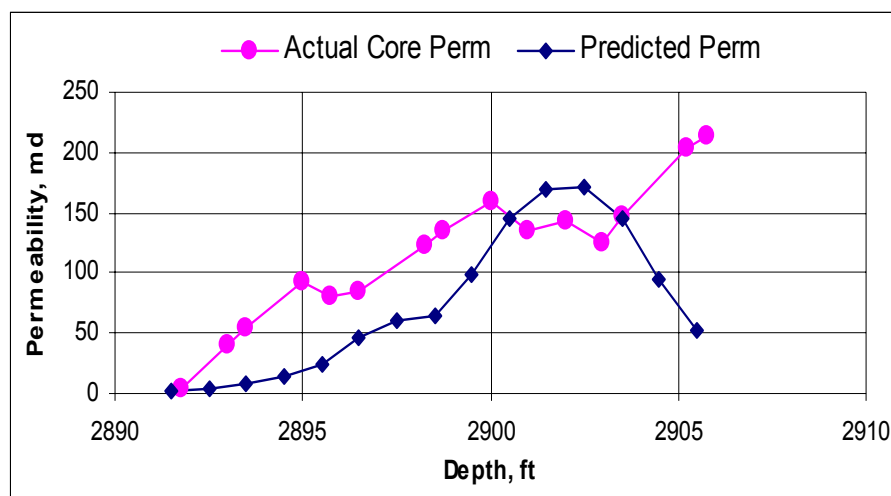

Figure 5.14 (a) Actual and measured permeability for $\mathbf{P}$. Horner 9

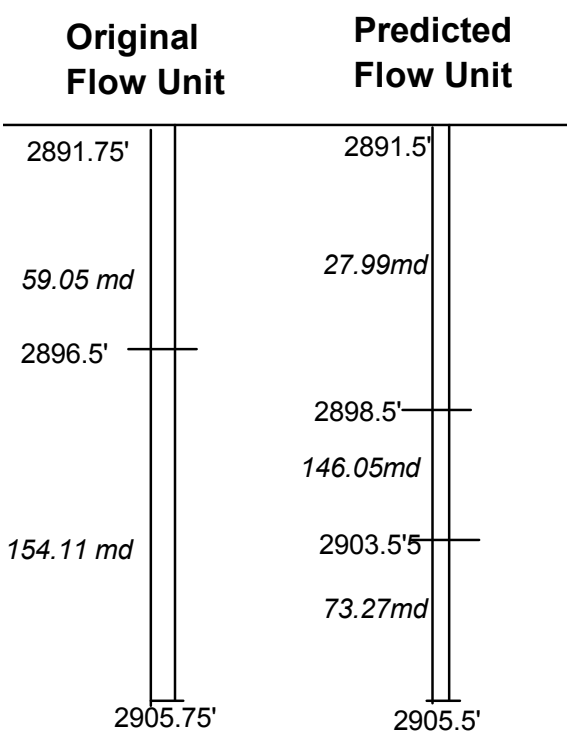

Figure 5.14 (b) Actual and predicted flow units for P. Horner 9

The Figure 5.14 shows that the predicted model divides the well in three flow zones where as the actual data shows that the well has two zones.

The flow strata through the wells in data Set $\mathrm{I}$ is depicted in Figure 5.15. Figure 5.16 represents the flow unit strata when P. Horner 9 with predicted permeability is included into the computation. A comparison of Figure 5.16 and Figure 5.4 (flow unit strata using measured permeability data for all wells including $\mathrm{P}$. 
Horner 9) shows that though the continuity of the high permeability flow stratum is generally maintained the predicted high permeability zone is narrower.

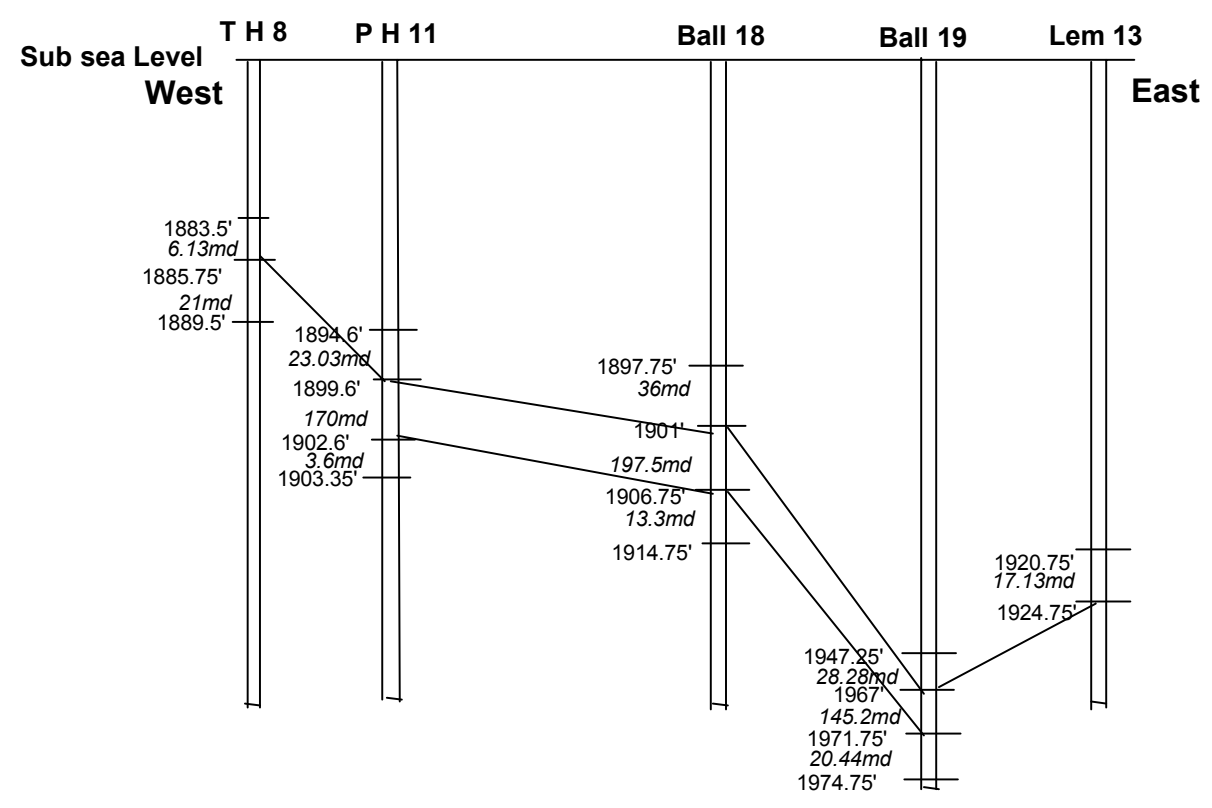

Figure 5.15: Correlation of flow units for Development Data Set in Test 5 (except P. Horner 9) 


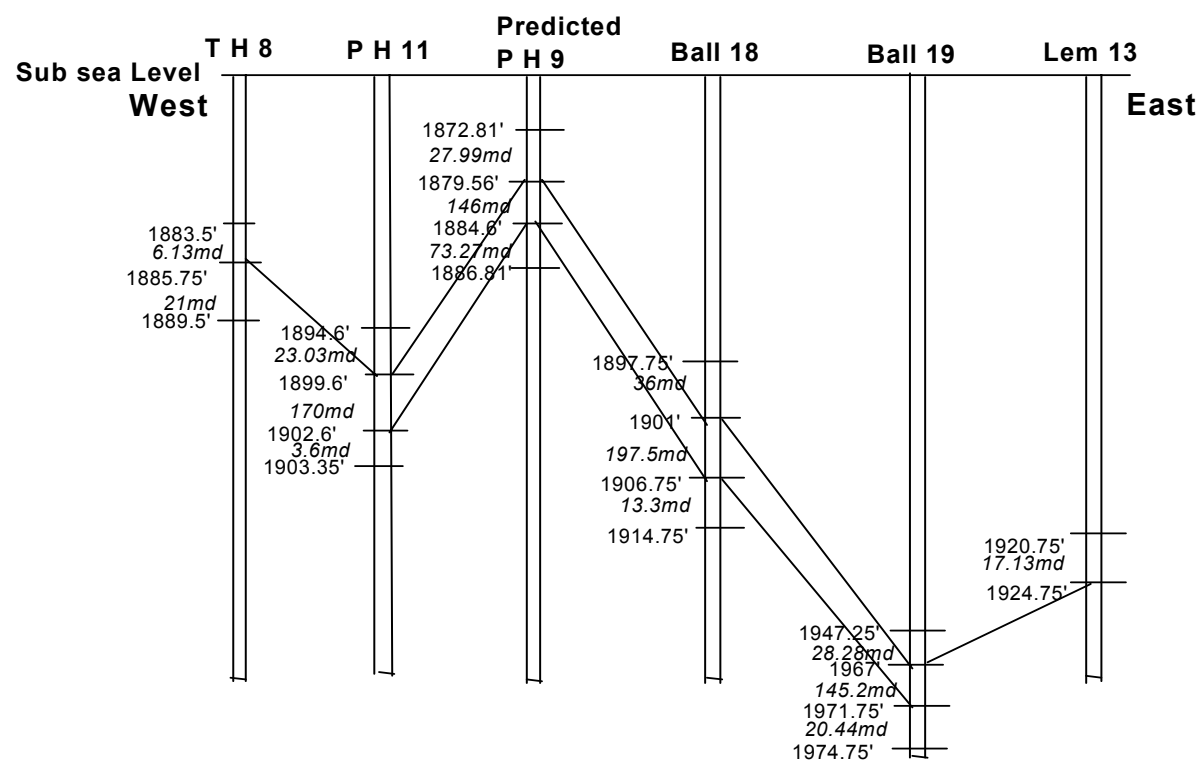

Figure 5.16: Correlation of flow units for Development Data Set in Test 5 with predicted flow unit of P. Horner 9.

\subsection{Discussion of results for Test 6}

In this case data is divided into following two data sets:

Set I: Development Data Set (F.R.Ball 18, F.R.Ball 19 Lemasters 13, T.Heirs 8, and P.Horner 9)

Set II: Validation Data Set (P. Horner 11).

The permeability prediction model is given by:

$\log K=17.084-6.51 X$,

where $\mathrm{X}$ is the $\log$ density of the well. 
Figure 5.17 (a) depicts the comparison of the predicted permeability values and measured values at different depths of the well. The predicted flow units are compared with the flow units obtained by using measured permeability (data Set II) in Figure 5.17 (b).

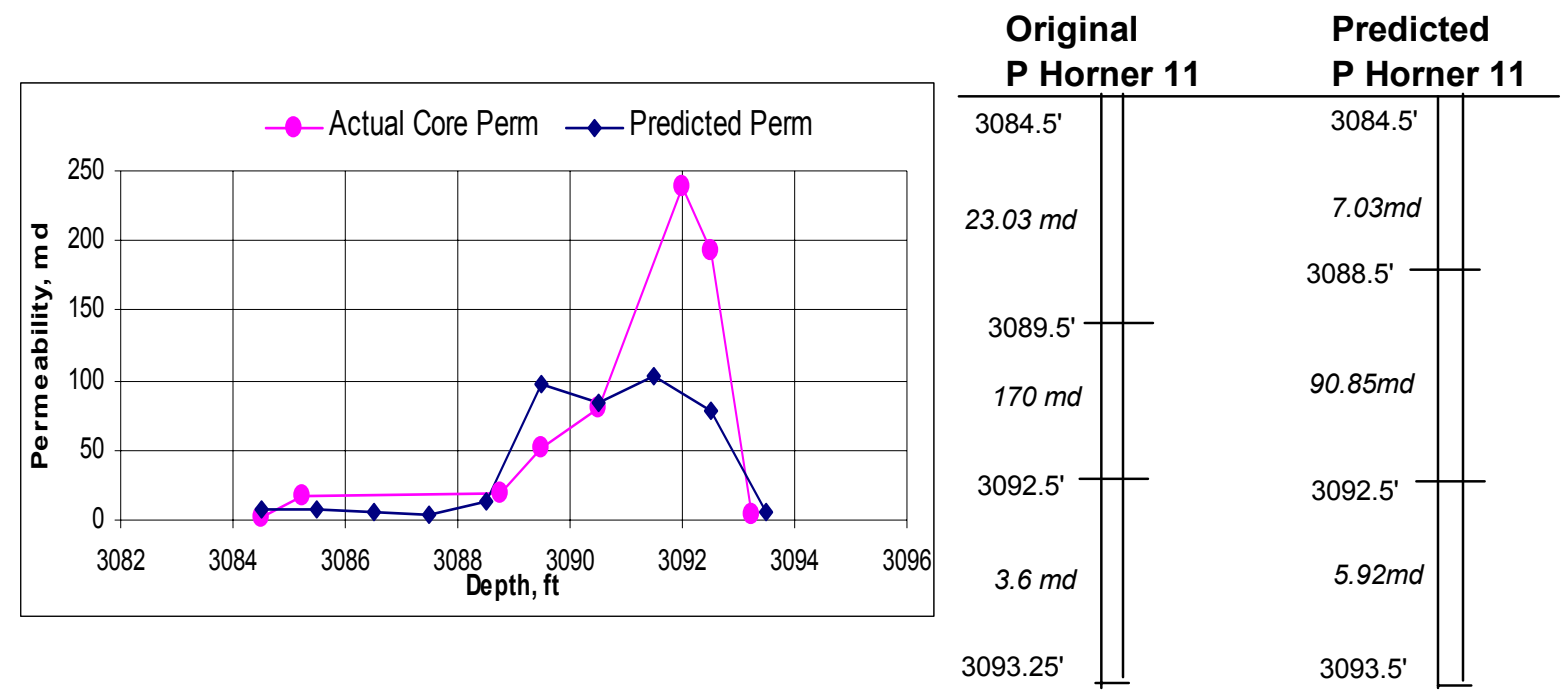

Figure 5.17 (a) Actual and measured permeability for $\mathbf{P}$. Horner 11
Figure 5.17 (b) Actual and predicted flow units for P. Horner 11

The Figure 5.17 (a) shows that the predicted permeability and actual permeability significantly differs between depth of 3091'-3093'. This wide variation in this particular case is not quite understood. The reasons may be one of the following two:

i. the actual log data might be faulty

ii. the linear model is not capable of capturing the variations under all situations. Please refer to Appendix $B$ to note that $R^{2}$ values 
for the linear model lies between $0.597-0.646$. The low $\mathrm{R}^{2}$ values indicate that the model can be strengthen either by incorporating more independent variables or by assuming polynomial model.

As a result of the variation between predicted and actual permeability values, the mean predicted permeability value for the high flow zone is significantly lower than the actual mean permeability of the higher flow zone (Figure 5.17(b)).

The flow strata through the wells in data Set I is depicted in Figure 5.18. According to flow unit correlation calculation between adjacent wells, it has been observed that there is a statistical significance created super high permeability zone (197 md) and high permeability zone (145 md and $154 \mathrm{md})$, but using engineering judgment, these two zones are combined and designated as a high flow zone. Figure 5.19 represents the flow unit strata when P. Horner 11 with predicted permeability is included into the computation. A comparison of Figure 5.19 and Figure 5.4 (flow unit strata using measured permeability data for all wells including P. Horner 11) shows that the high permeability flow stratum is not continued through PH 11. Again the reason lies in the fact that the predicted permeability of PH 11 were quite low in comparison to the actual values. This sudden drop of permeability caused discontinuous flow. 


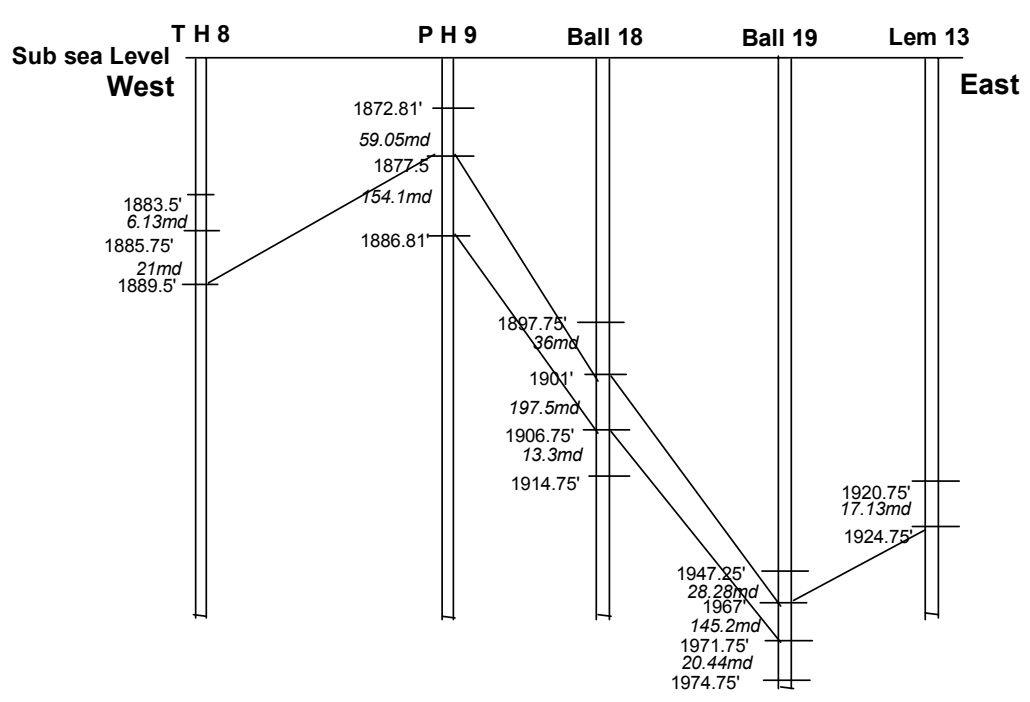

Figure 5.18: Correlation of flow units for Development Data Set in Test 6 (except P. Horner 11)

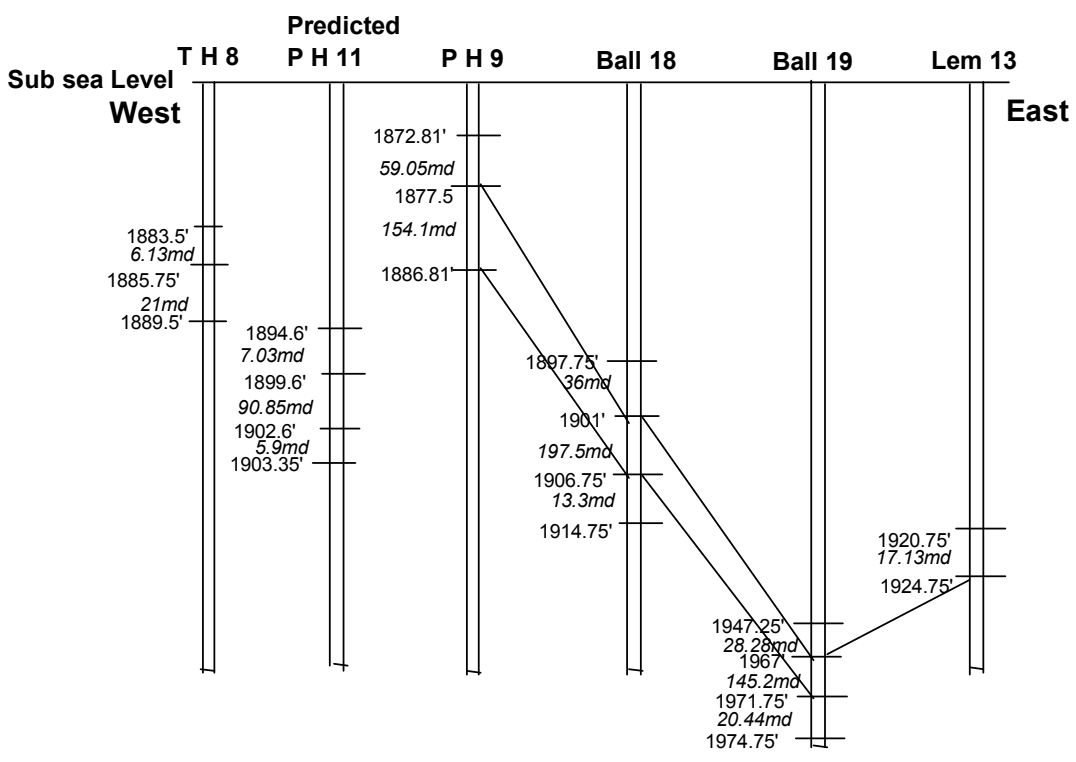

Figure 5.19: Correlation of flow units for Development Data Set in Test 6 with predicted flow unit of P. Horner 11. 


\section{CHAPTER SIX}

\section{CONCLUSIONS AND RECOMMENDATIONS}

The following conclusions could be made based on the results obtained from the study:

1. A model for predicting flow units has been developed using log density and limited core permeability data from six wells.

2. A linear relationship between density from $\operatorname{logs}, \mathrm{D}$, and logarithm of core permeability, $\mathrm{k}$, has been established to predict permeability in wells without core data.

3. Statistical zonation technique can successfully identify flow units in wells with core permeability data.

4. A methodology was developed to extend the application of statistical zonation techniques to the wells without core data by utilizing the predicted permeability values from log data.

5. The accuracy of the methodology was verified by comparing the original flow units with the predicted flow units in the wells with core data. 
The following recommendations could be made:

1. The correlation between density and permeability is not very strong. More accurate permeability prediction can improve the results.

2. A multiple regression technique using log density, gamma ray and core permeability may provide as a better permeability prediction tool. 


\section{REFERENCES:}

1. Testerman, J. D. "A Statistical Reservoir-Zonation Technique." Soc. Petrol. Engr. JPT, Aug. 1962, pp. 889-893.

2. Hohn, M., Avary, K. L., McDowell, R., Matchen, D., "Reservoir Characterization of Upper Devonian Gordon Sandstone, Stringtown Oilfield, Northwestern West Virginia", WVU and Appalachian Oil and Natural Gas Research Consortium, Semi-Annual Report, April 1999.

3. Aminian, K., Ameri, S., Avary, K. L., Bilgesu, H. I., Hohn, M.E., McDowell, R. R., and Matchen, D. L. "Reservoir Characterization of Upper Devonian Gordon Sandstone”, Jacksonburge, Stringtown Oilfield, Northwestern West Virginia. Semi Annual Report. West Virginia University, October 1999.

4. Beghtol, LeRoy A.: "A Statistical Approach to the Zonation of a Petroleum Reservoir", Master's Thesis, Missouri School of Mines (1958).

5. Fisher, W. D.: “On Grouping for Maximum Homogeneity”, Jour. Of Am. Stat. Assn. (1958) 53, No. 284.

6. Graybill, F. A.: "An Introduction to Linear Statistical Hypothesis." McGraw - Hill, New York - 1961.

7. Harter, H. L.: Critical Values for Dunkan's New Multiple Range Test", Biometrics (1960) 16, 671.

8. Amaefule, J.O. A flow unit approach on integrated reservoirs. World Expo, 1995. pp 25-31. 
9. Abbaszadeh, M., Fujii, H., Fujiimoto, F. Permeability prediction by hydraulic flow units-theory and applications, SPE 30158, Proceedings of SPE Petrovietnam Conference, March 1-3, 1995.

10. Trudgen, P. and Hoffmann, F. "Statistically Analyzing Core Data." Soc. Petrol. Engr. JPT, April 1967, pp. 497-503.

11. Kramer, C. Y.: "Extension of Multiple Range Tests to Group Means with Unequal Numbers of Replications", Biometrics (1956) 12, 307.

12. Duncan, D. B.: "Multiple Range and Multiple F Tests”, Biometrics (1955) $11,1$.

13. Satter, A. and Thakur, G. C. Integrated Petroleum Reservoir Management. A Team Approach. PennWell Books, Tulsa OK. 1994.

14. Molnar, D., Aminian, K., and Ameri, S.: "The Use of Well Log Data for Permeability Estimation in a Heterogeneous Reservoir", SPE 29175, Proceedings of SPE Eastern Regional Conference, pp 167-180, 1994.

15. Tiab, D. and Donaldson, E.C. Petrophysics. Gulf Publishing Co., Houston, TX, 1996. pp 122.

16. Tiab, D.: Modern Core Analysis, Vol. I - Theory. Core Laboratories, Houston, TX, May 1993, 200 pp.

17. Amaefule, J. O., Altunbay, M. H., Tiab, D., Kersey, D. G. and Keelan, D. K. "Enhanced reservoir description using core and log data to identify hydraulic (flow) units and predict permeability in uncored intervals/wells.” Soc. Petrol. Engr. Paper No. 26436, 1993. 
18. Beggs, S.H., Chang, D.M. and Haldorsen, H.H.: "A Simple Statistical Method for Calculating the Effective Vertical Permeability of a Reservoir Containing Discontinuous Shales.” SPE - 14271 (1985).

19. McFadzean, T.B., "An Empirical Look at Bed Bounderies in a Sand Shale Sequence," Canadean Well Log Society Journal, V. 4, No. 1, pp. 7-23 (1971).

20. Neter, J., and Wasserman, W.: "Applied Linear Statistical Models," Richard D. Irwin, Inc., (1974).

21. Jensen, Jerry R., Lake, Larry W., Carbett, Patrick M. W., Goggin, David J., "Statistics for Petroleum Engineers and Geoscientist," Prentice Hall, New Jersey, 1997.

22. Grant, Eugene L., and Leavenworth, Richard S.: "Statistical Quality Control," sixth edison, McGraw-Hill Book Company, New York, 1998.

23. Keelan, D. K. "Core Analysis for Aid in Reservoir Description." Soc. Petrol. Engr. JPT, Nov. 1982, pp. 2,483-2,491.

24. Dharmawardhana, H.P.K., and Keller, G.V.: "Statistical Method for the Determination of Zone Boundaries Using Well Log Data.” 1985 SPE 14470.

25. Slater, George E and Durrer, Erwin J.:"A Statistical Method for Judging the Adequacy of a Numerical Reservoir Simulation.” 1971 SPE 3182.

26. Dorr, S., and Bercegeav, E.P.: "Estimation of Reservoir Oil-in-Place Using Statistical Confidence Intervals.” 1972 SPE-4297. 
27. Luffel, D.L., and Guidry, F.K.: "New Core Analysis Methods for Measuring Reservoir Rock Properties of Devonial Shale.” 1992 SPE 20571.

28. Keolan, Dare K.: "Core Analysis for Aid in Reservoir Description.” 1982 JPT SPE 10011.

29. Lee, K.S., Miller, M.A., and Sepehrnoori, K.: "Statistical Analysis of well Productivity in Heterogeneous Reservoir.” 1996 SPE 36988.

30. Busch, J.M., Fortney,W.G. and Berry, L.N.: "Determination of Lithology From Well Logs by Statistical Analysis.” 1987 SPE 14301.

31. Cox, Dave O, and Chesnut, Dwayne A.: "Isotropic or Anisotropic Permeability a Statistical Analysis.” 1977 SPE 6674.

32. Dare K. Keelan : "Core Analysis Techniques and Applications." 1972 SPE 4160

33. Mulyadi, H., Amin, R., Curtin, U., Kennaird, Bakker, G., Palmer, I., Nispen, D. Van.: "Measurement of Residual Gas Saturation in WaterDriven Gas Reservoirs: Comparison of Various Core Analysis Techniques." 2000 SPE 64710.

34. "Applied Linear Statistical Models" by John Neter, William Wasserman, Michael H. Kutner. Homewood, Ill., R. D. Irwin, 1974. 


\section{APPENDIX A.}

Log Density and Core Permeability distribution in cored wells. 


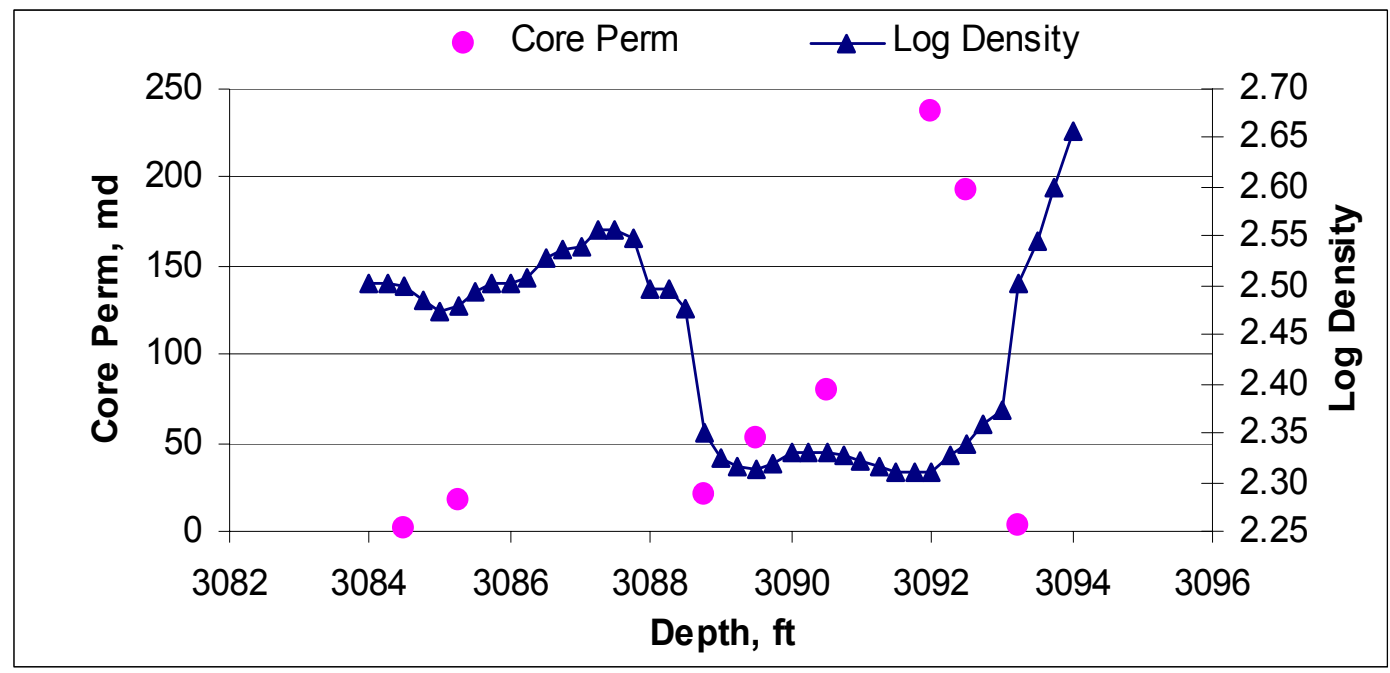

Figure A. 1 Log Density and Core Permeability distribution for core well F. R. Ball 18

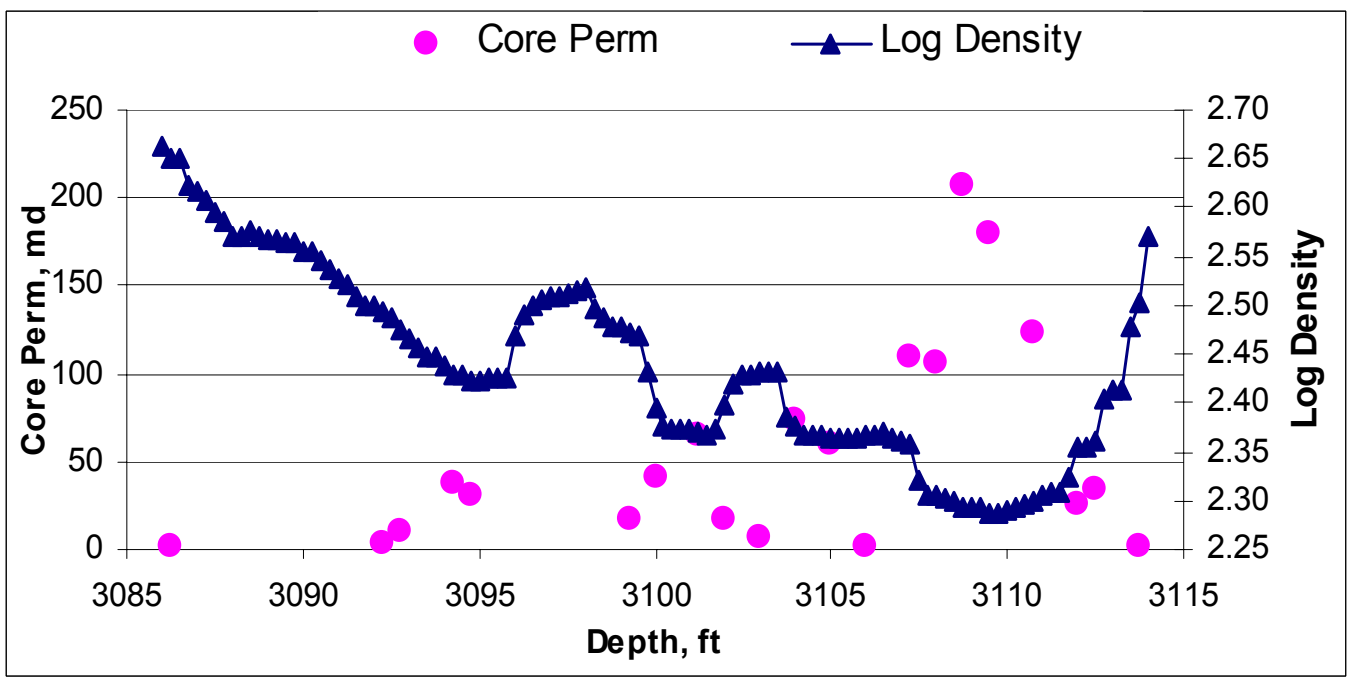

Figure A. 2 Log Density and Core Permeability distribution for core well F. R. Ball 19 


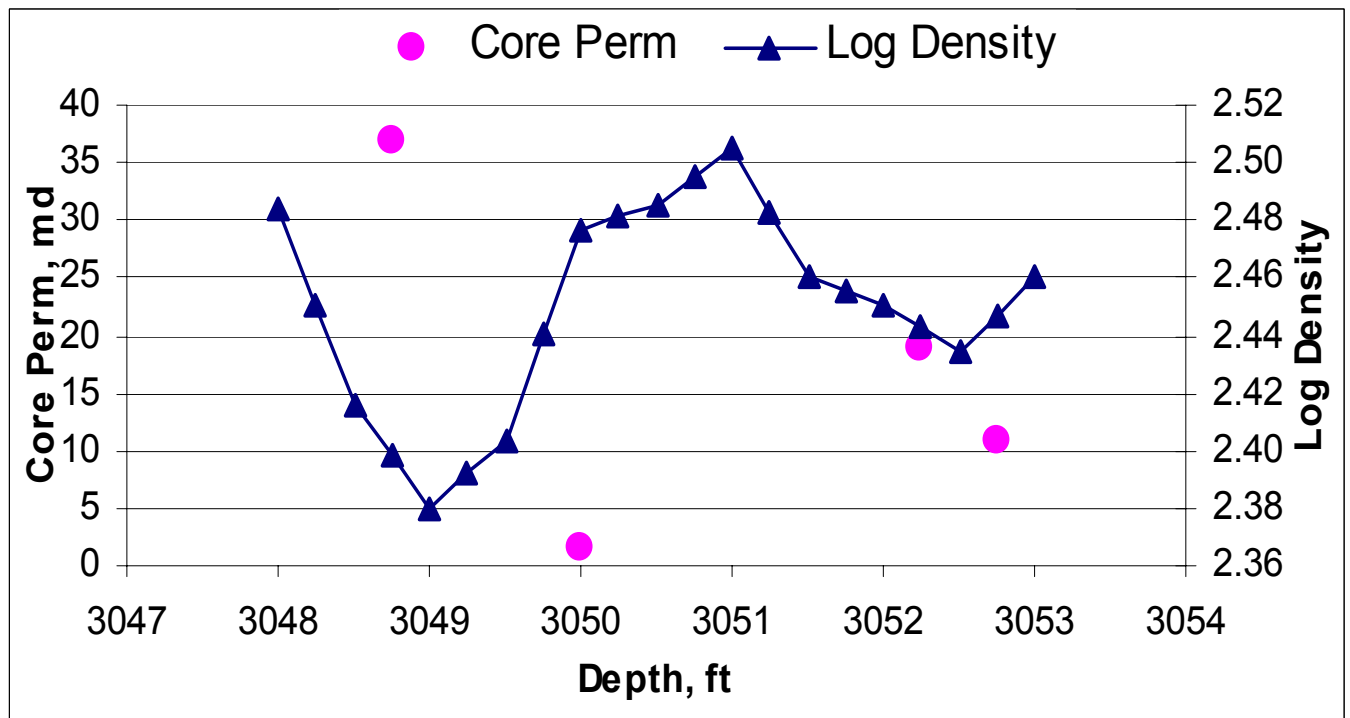

Figure A. 3 Log Density and Core Permeability distribution for core well Lemasters 13

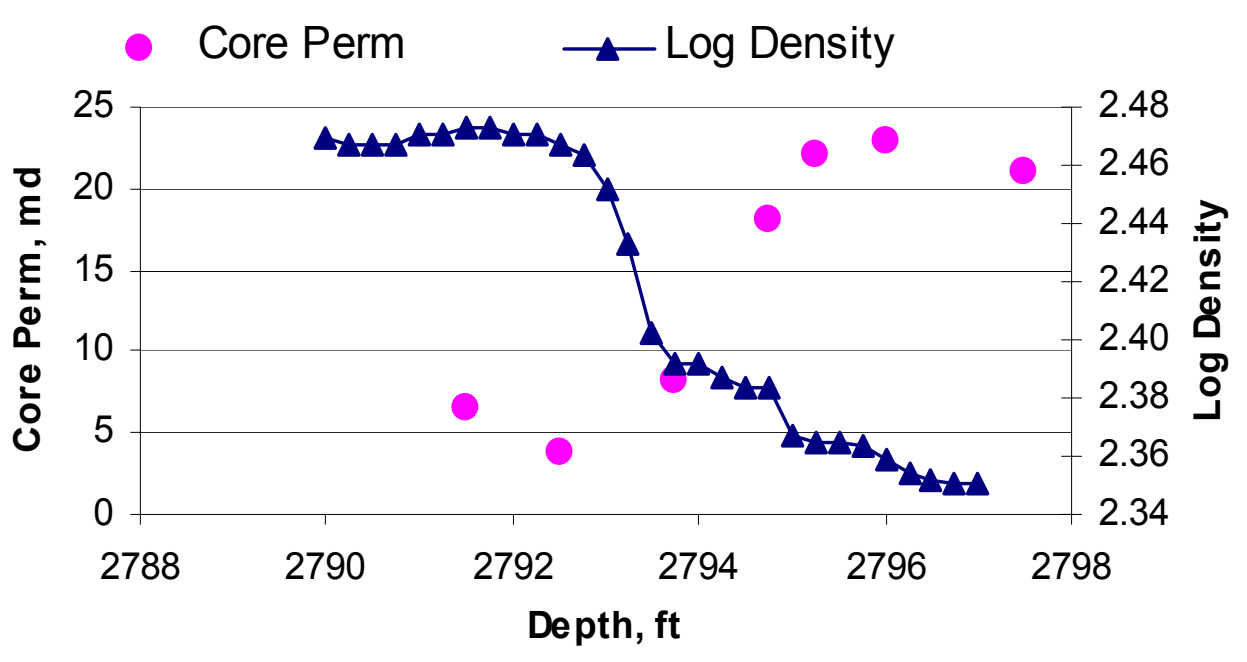

Figure A. 4 Log Density and Core Permeability distribution for core well T. Heirs 8 


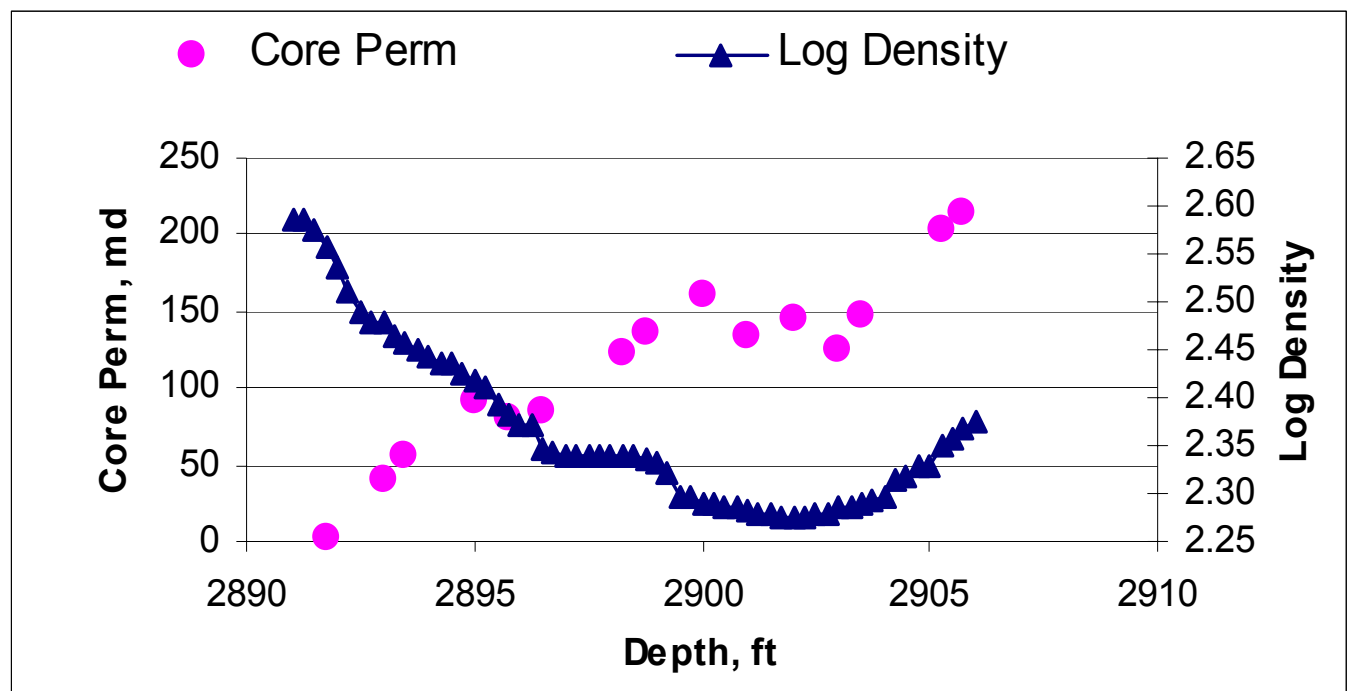

Figure A. 5 Log Density and Core Permeability distribution for core well P. Horner 9

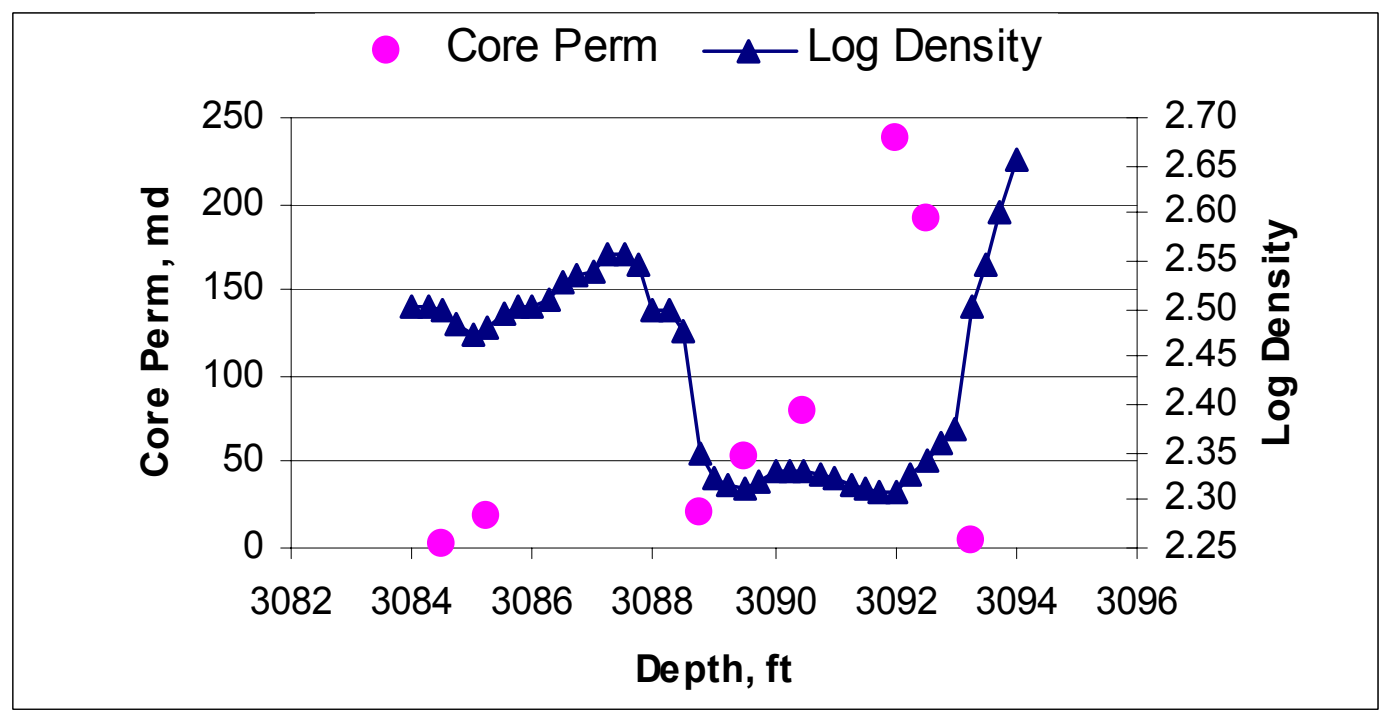

Figure A. 6 Log Density and Core Permeability distribution for core well P. Horner 11 


\section{APPENDIX B.}

Permeability predictions in cored wells using Linear Correlation 


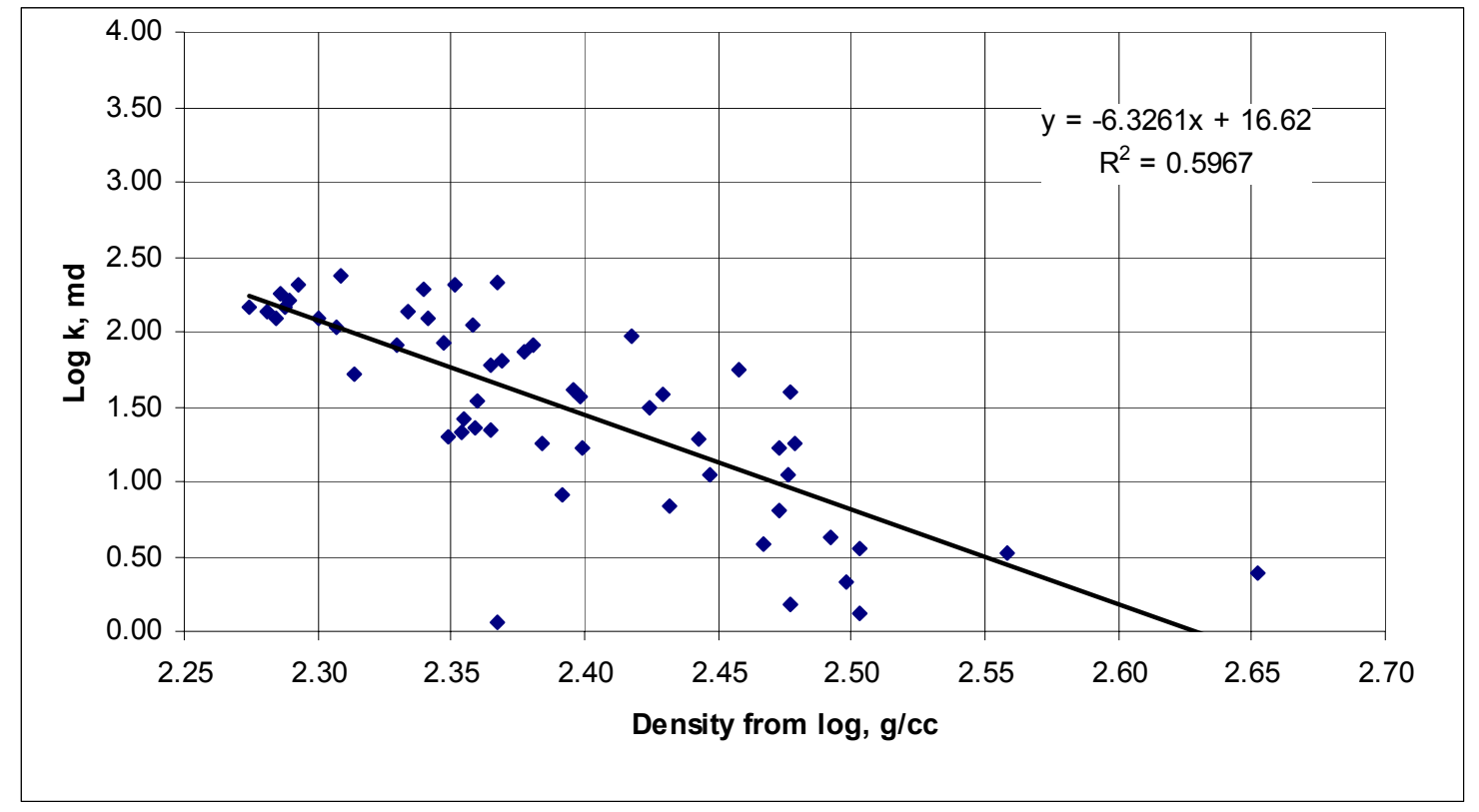

Figure B.1 Linear correlation between Density from well log and logarithmic core permeability for Test 1 (except Ball 18).

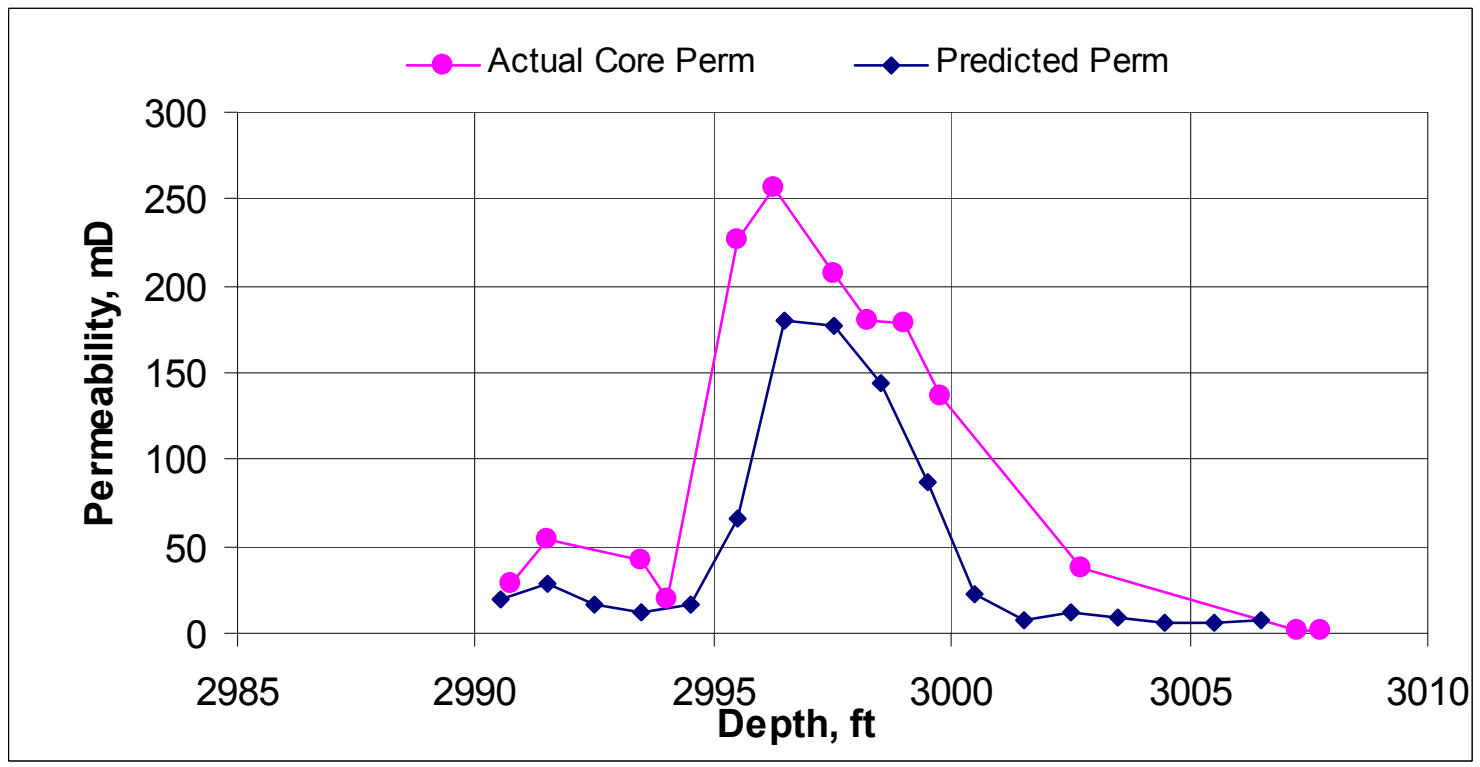

Figure B. 2 Permeability Prediction for F. R. Ball 18 


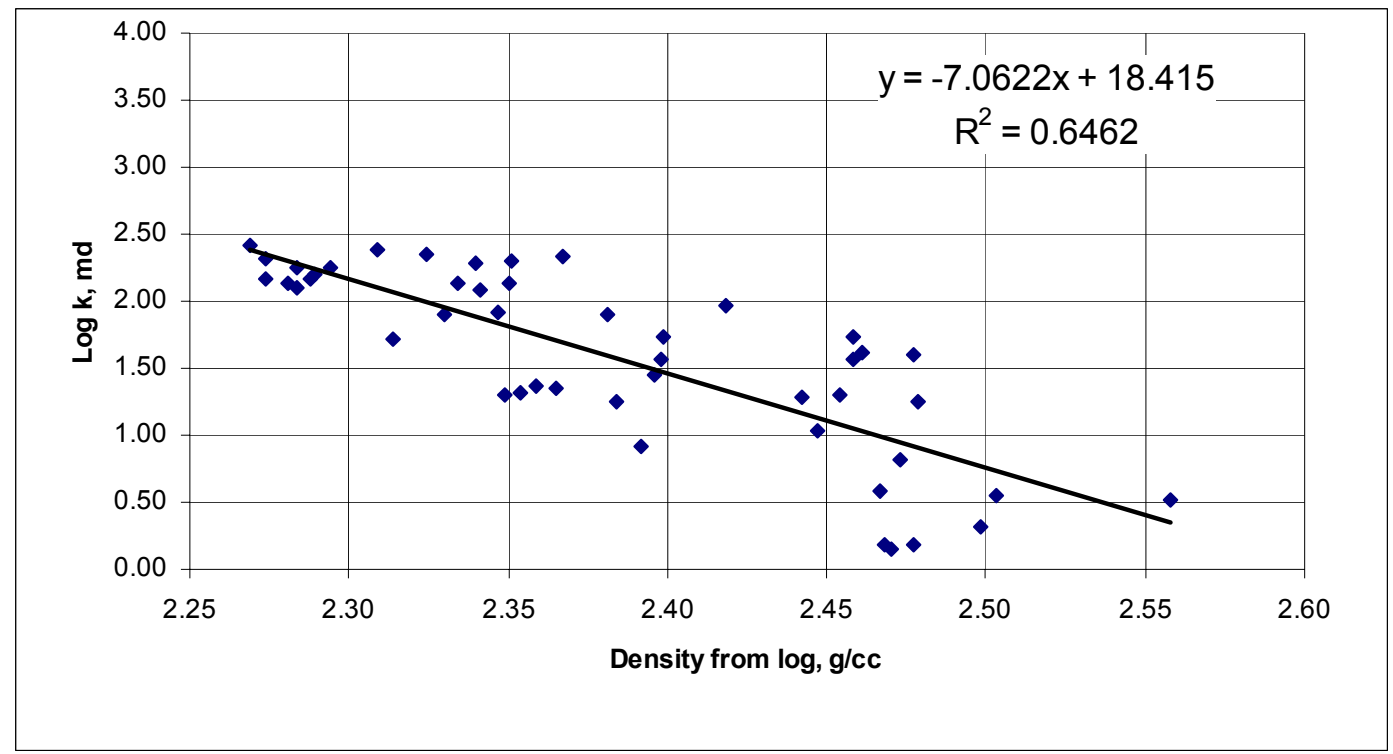

Figure B.3 Linear correlation between Density from well log and logarithmic core permeability for Test 2 (except Ball 19).

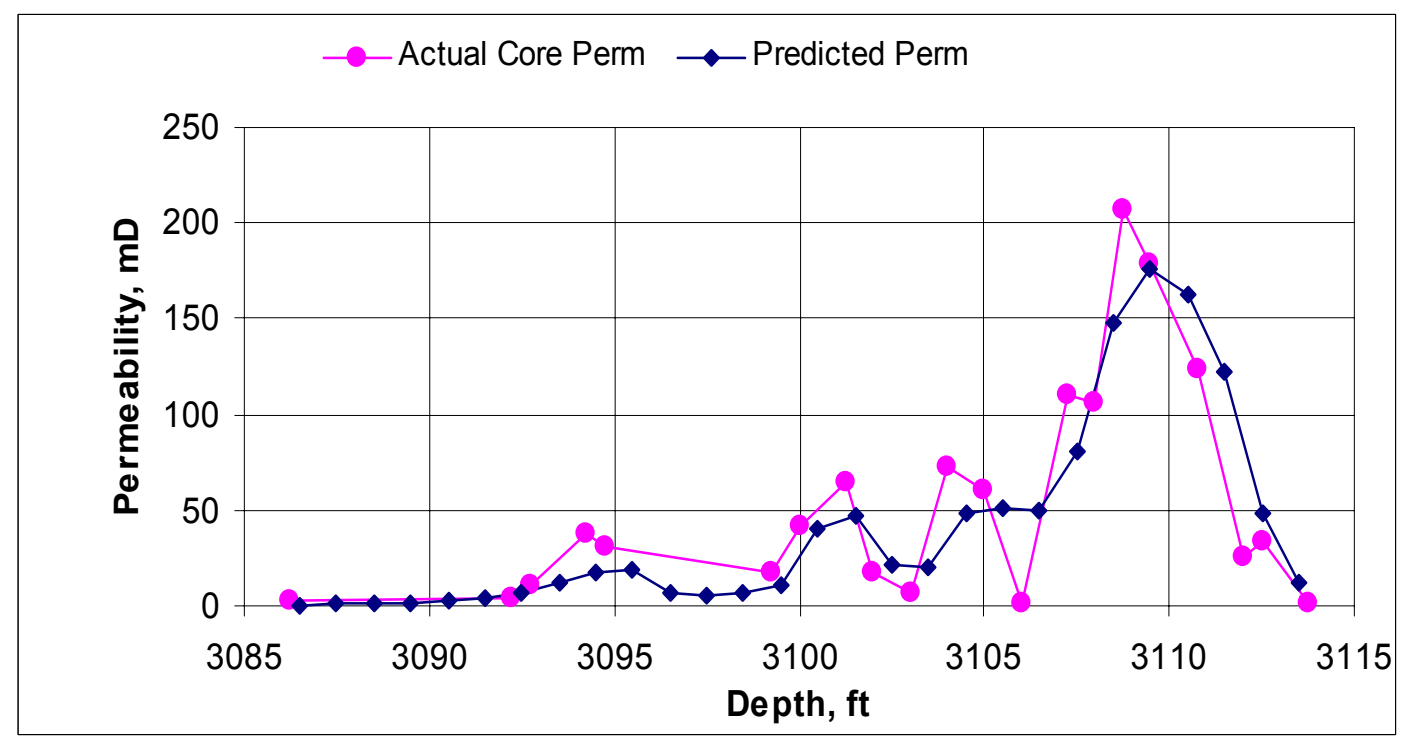

Figure B. 4 Permeability Prediction for F. R. Ball 19 


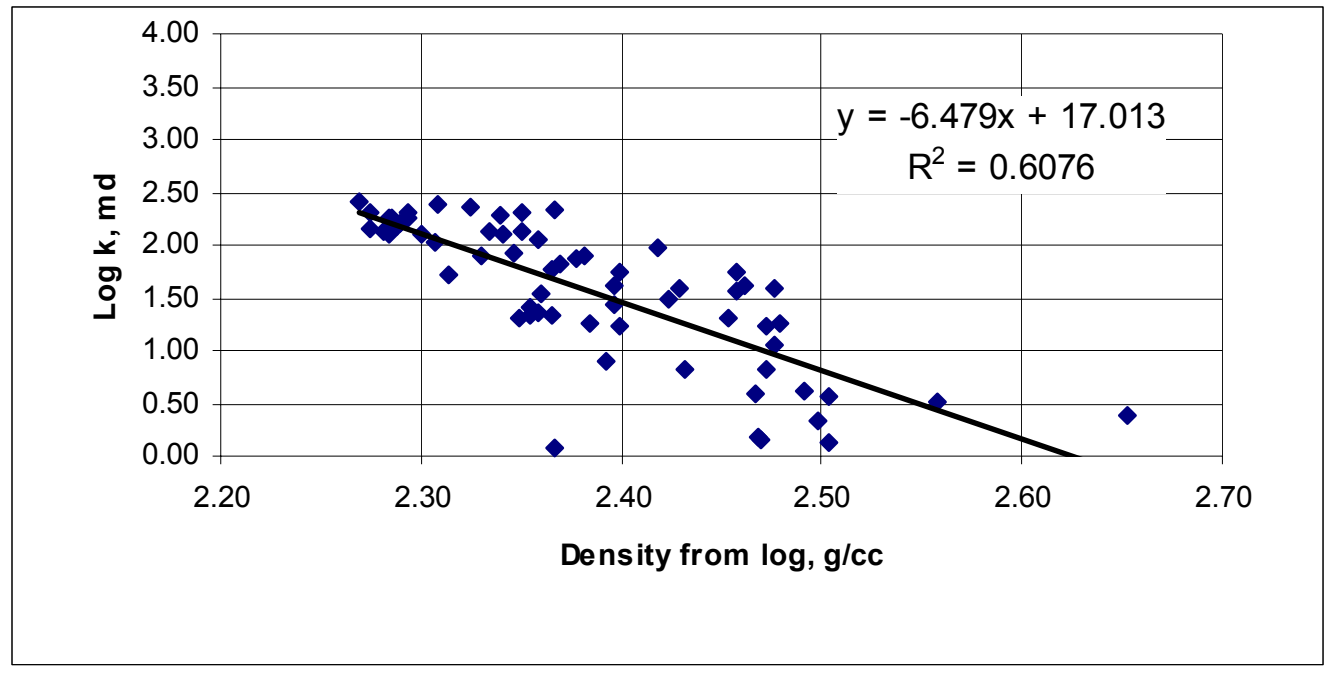

Figure B.5 Linear correlation between Density from well log and logarithmic core permeability for Test 3 (except Lemasters 13).

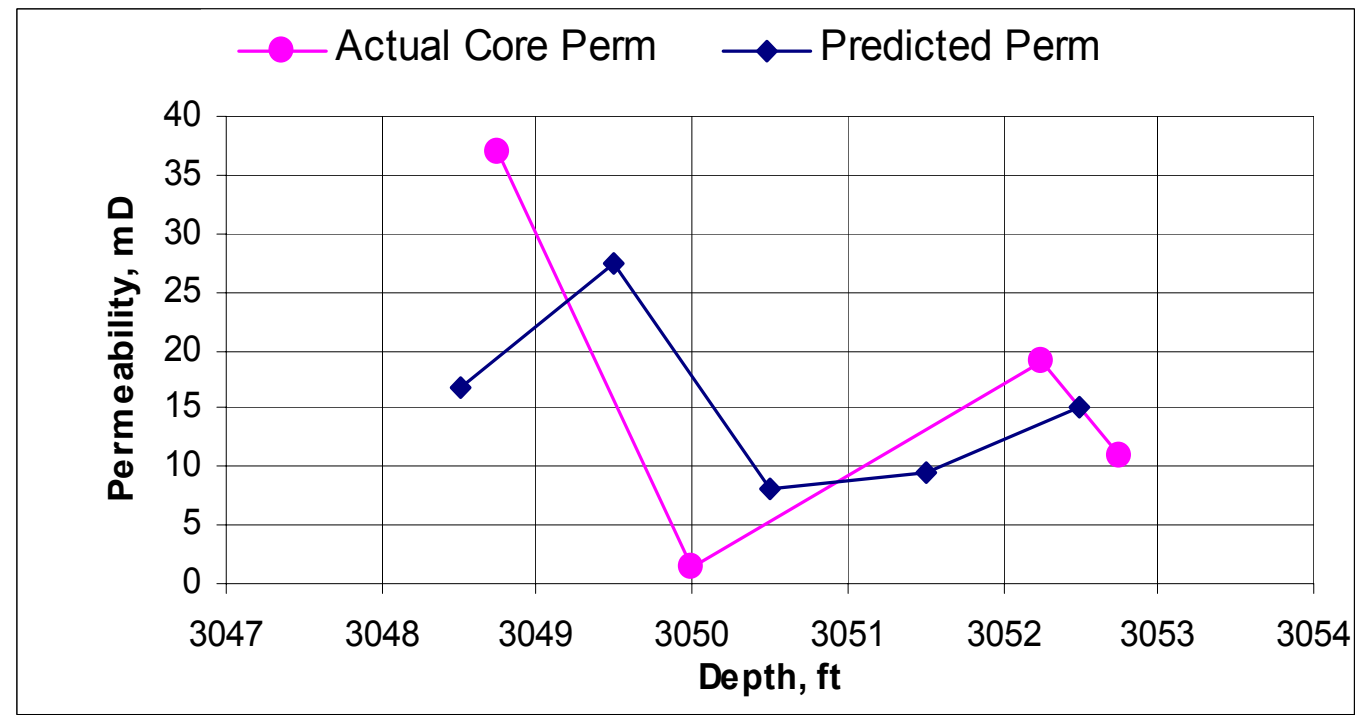

Figure B.6 Permeability Prediction for Lemasters 13 


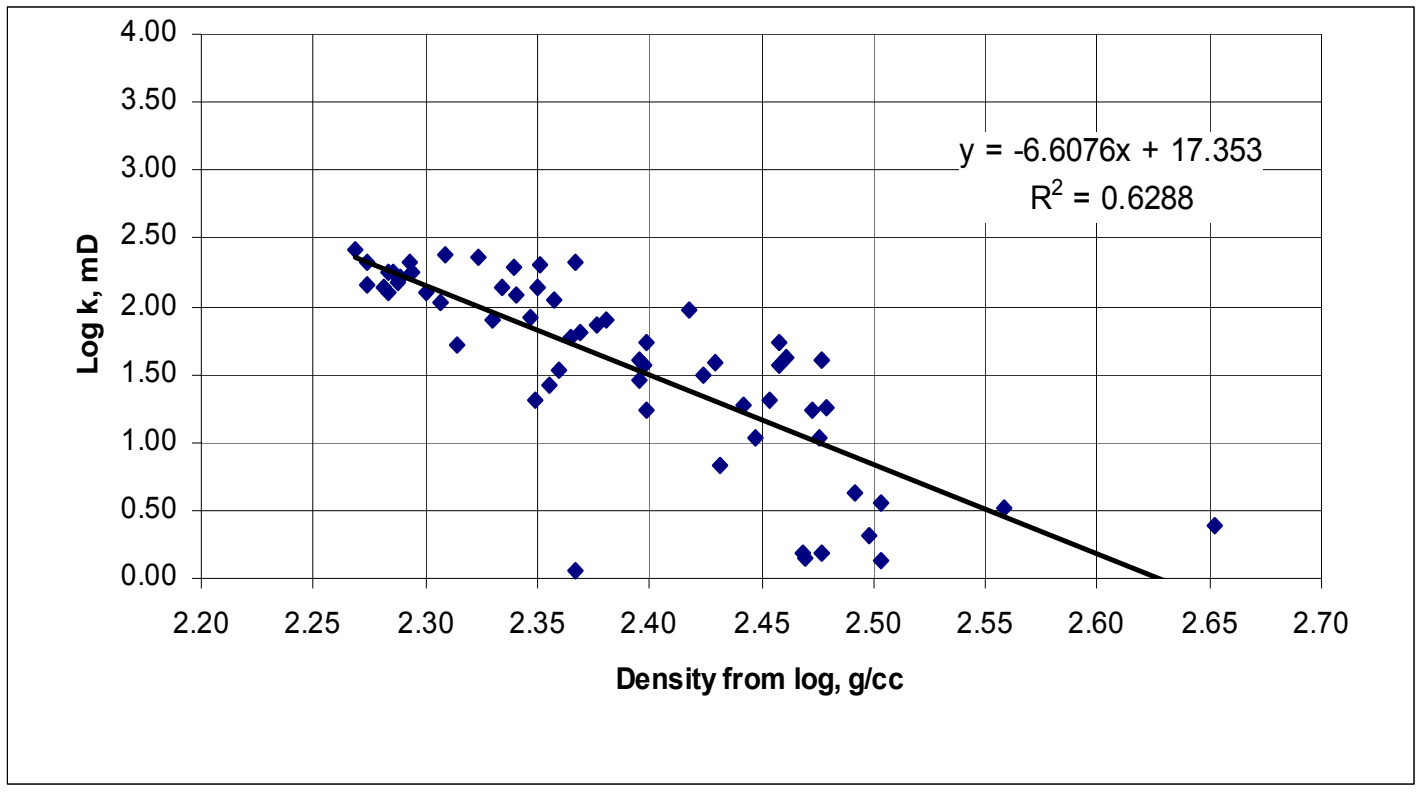

Figure B.7 Linear correlation between Density from well log and logarithmic core permeability for Test 4 (except T. Heirs 8).

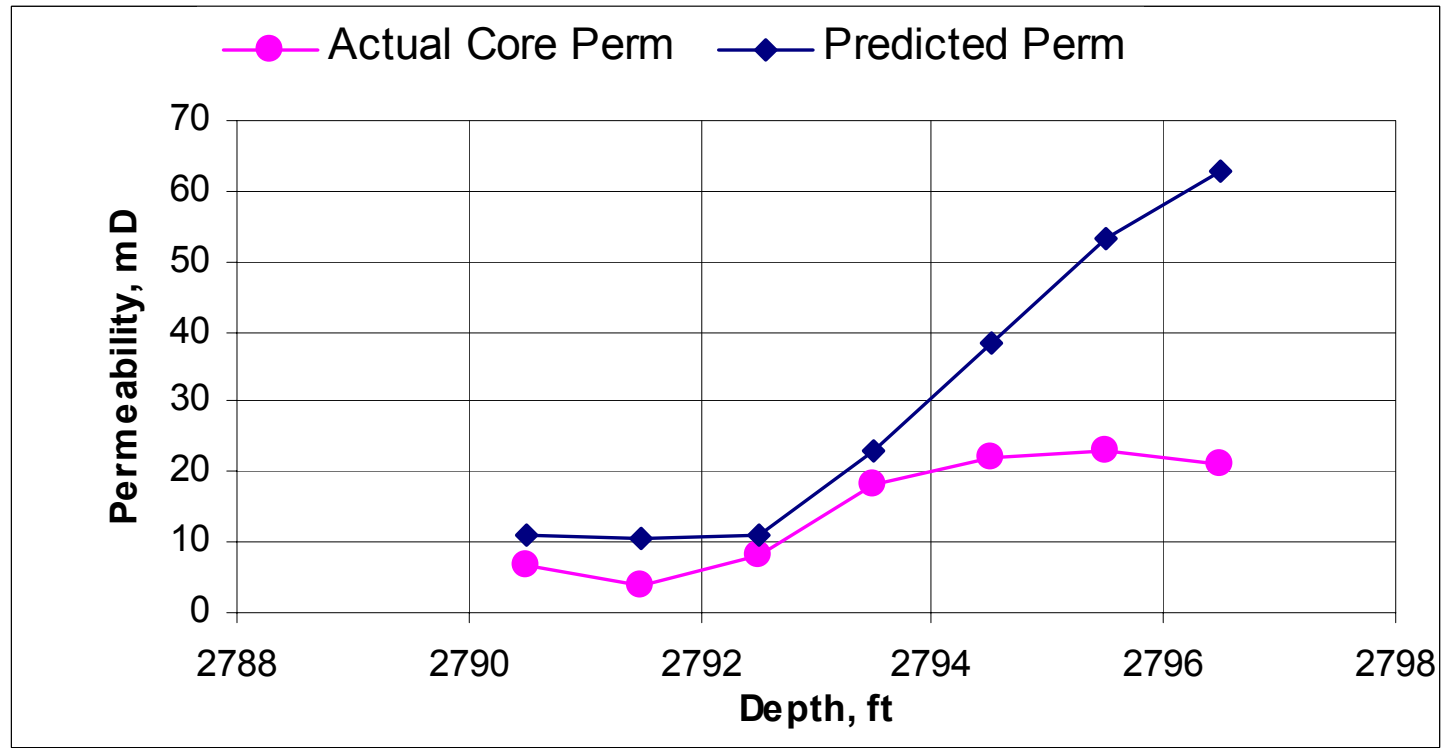

Figure B. 8 Permeability Prediction for T. Heirs 8 


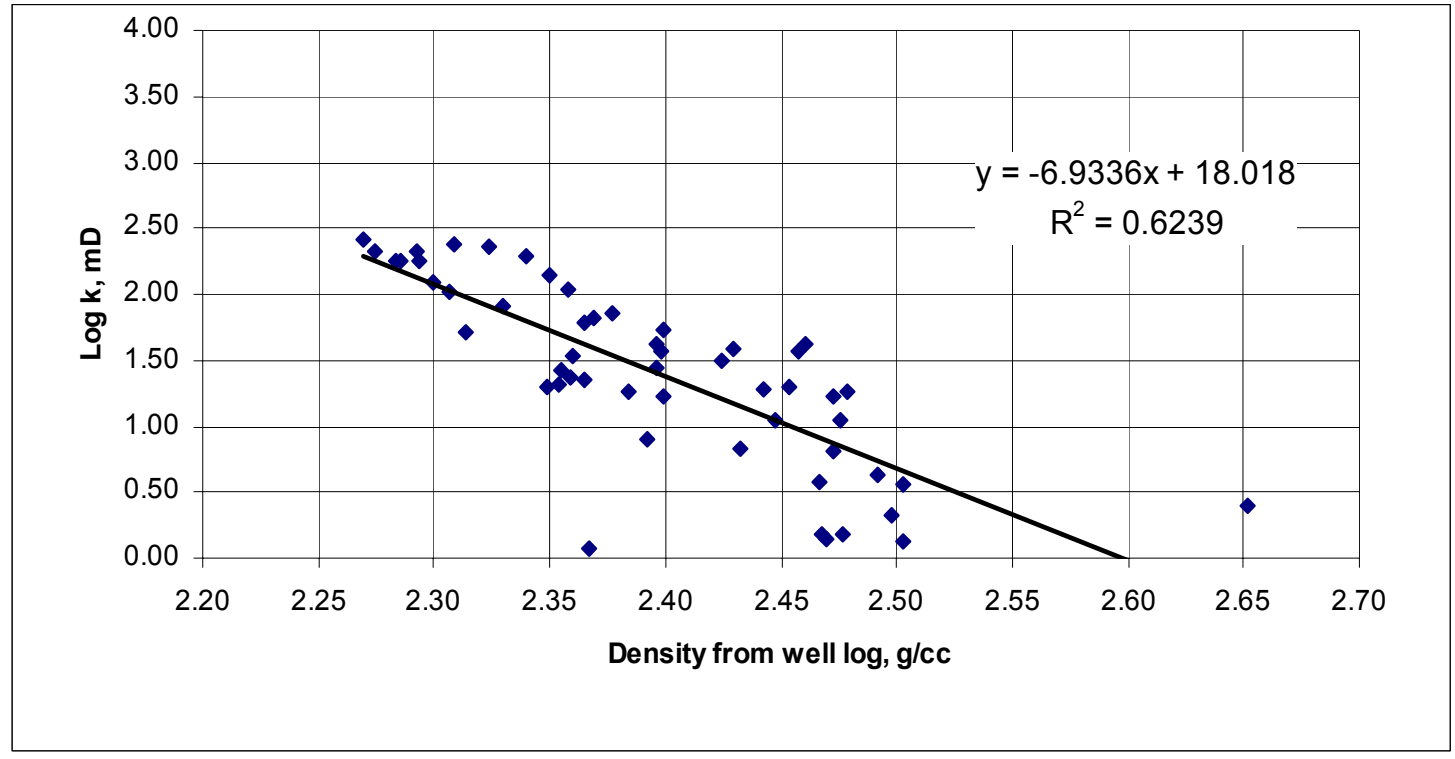

Figure B.9 Linear correlation between Density from well log and logarithmic core permeability for Test 5 (except $P$. Horner 9).

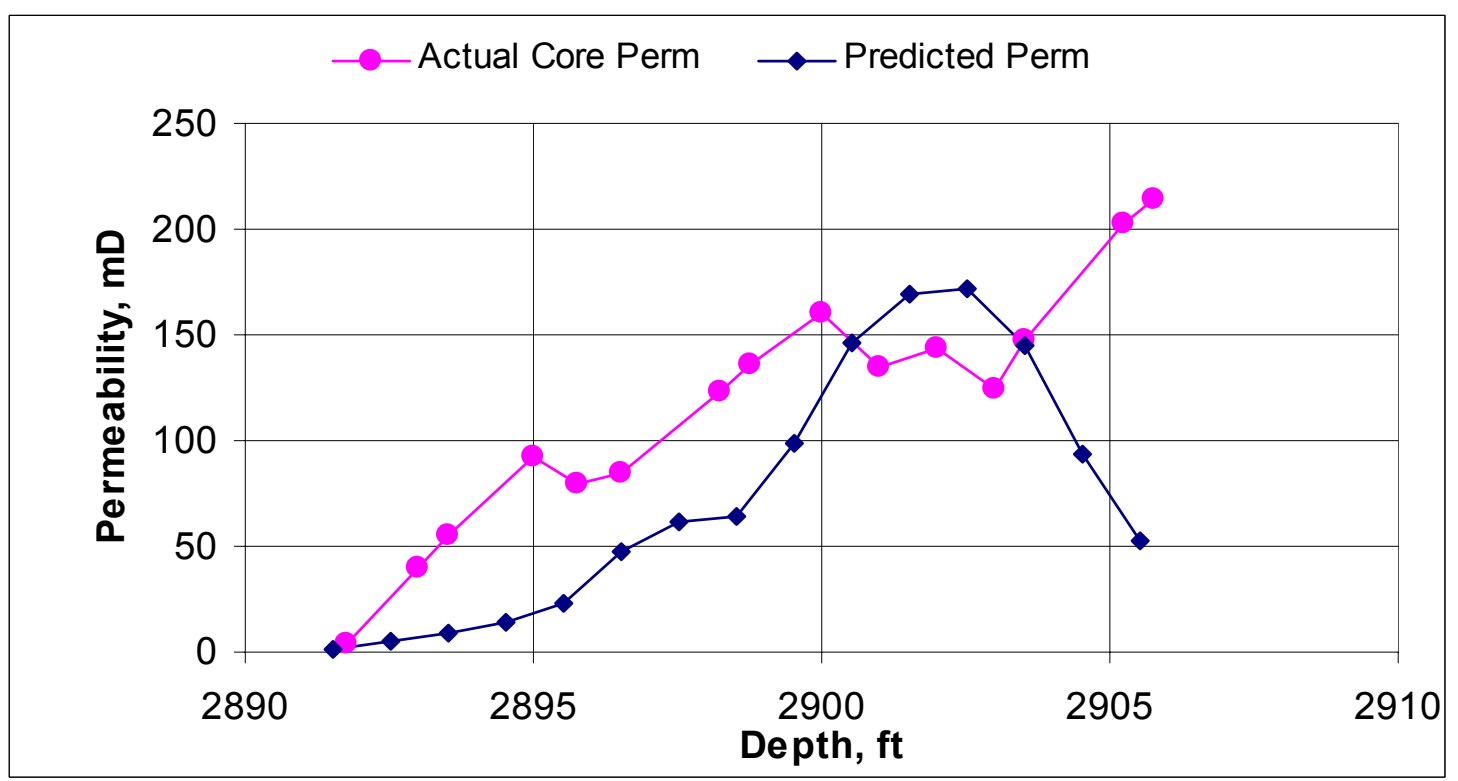

Figure B. 10 Permeability Prediction for P. Horner 9 


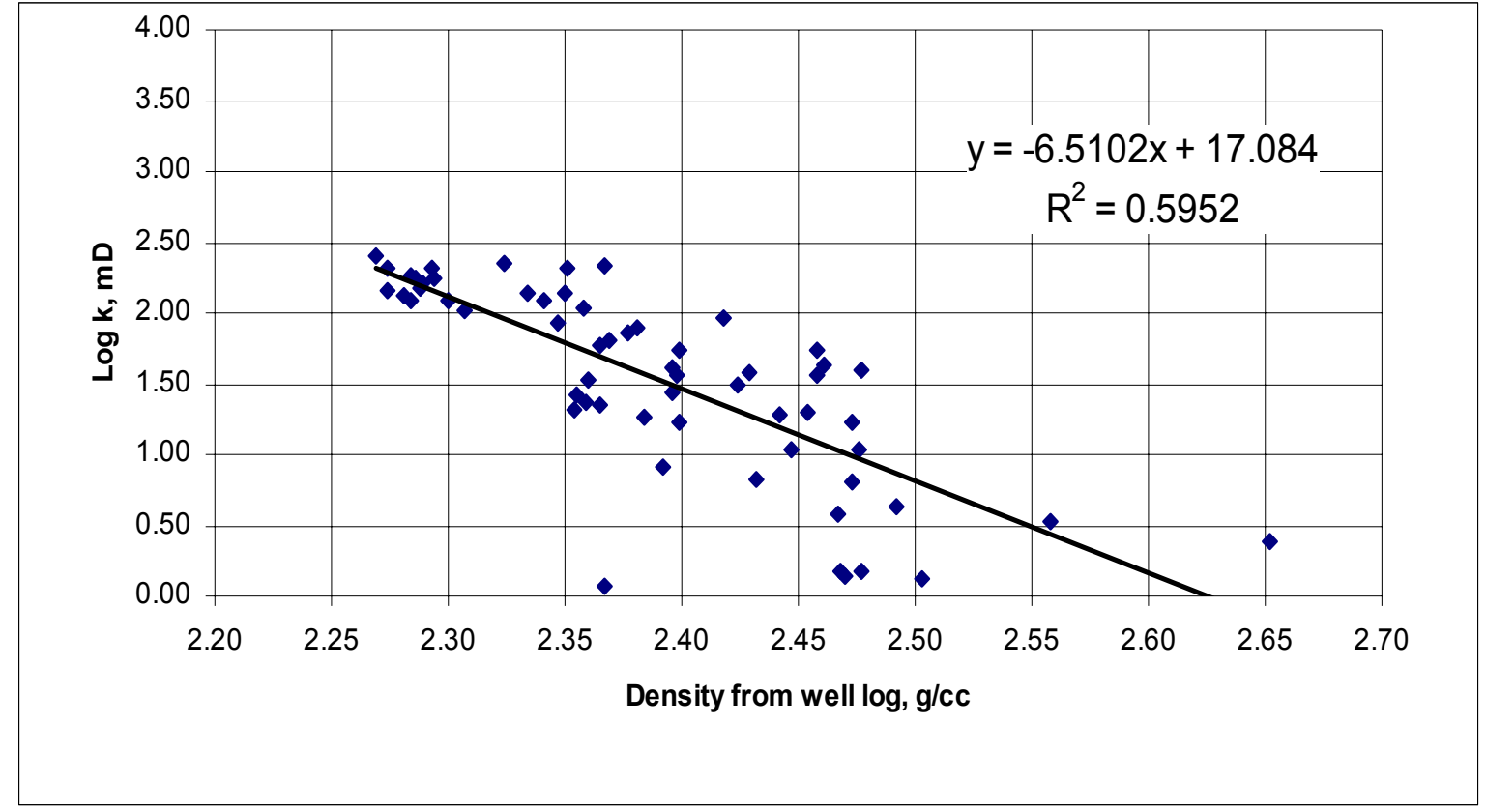

Figure B.11 Linear correlation between Density from well log and logarithmic core permeability for Test 6 (except P. Horner 11).

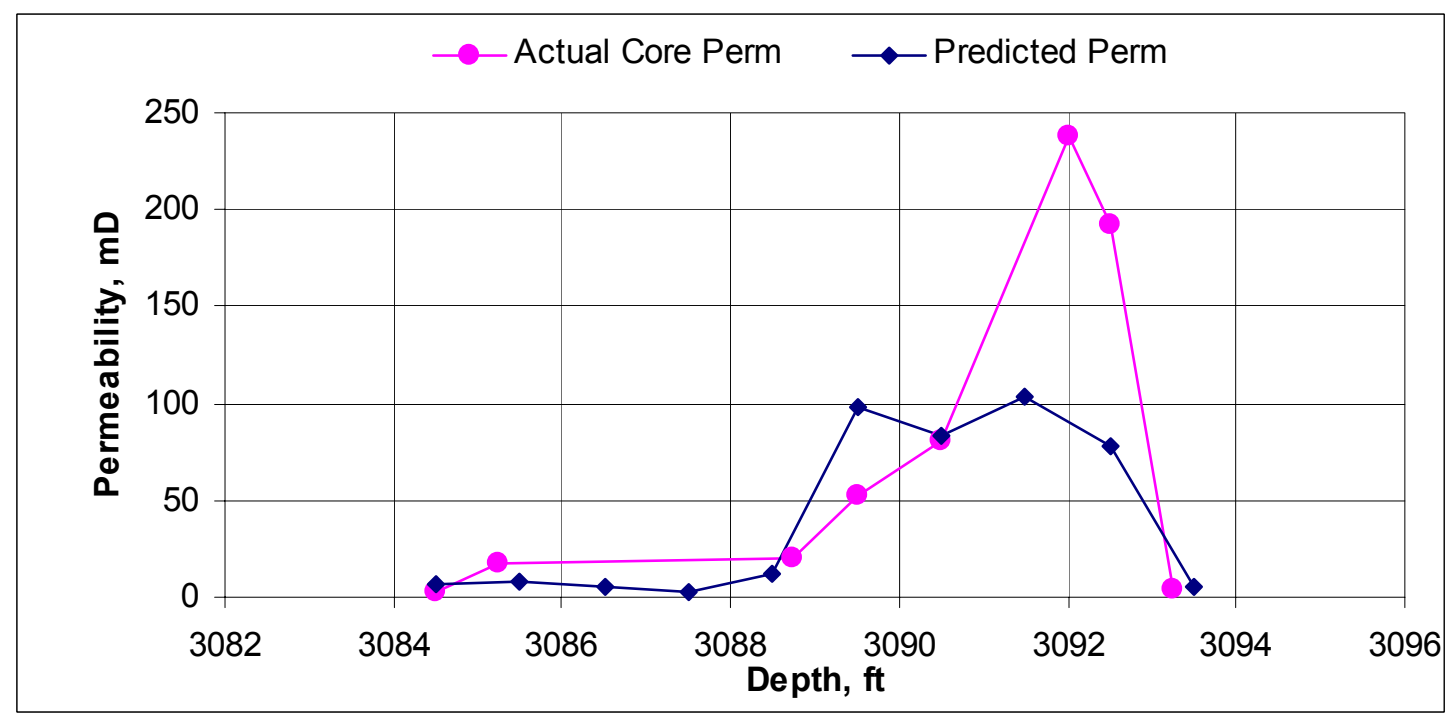

Figure B. 12 Permeability Prediction for P.Horner 11 


\section{APPENDIX C.}

Sample calculation to identify flow units and their correlation 


\section{Part A:}

\section{Sample calculation to identify flow unit for Ball 18 (Table D1)}

Applying Eq. 1 in first line in Table D.1:

Variance between zones, $B=\frac{1}{L-1}\left[\sum_{i=1}^{L} m_{i}\left(\overline{k_{i}}-\overline{k_{. .}}\right)^{2}\right]$

$$
\begin{aligned}
B & =\frac{1}{2-1}\left[\frac{(28)^{2}}{1}+\frac{(1340.90)^{2}}{12}-\frac{(1368.9)^{2}}{13}\right] \\
& =6473.23
\end{aligned}
$$

Eq. 2 :

The pooled variance within zones, $W=\frac{1}{N-L}\left[\sum_{i=1}^{L} m_{i} \sum_{j=1}^{m_{i}}\left(k_{i j}-\bar{k}_{i .}\right)^{2}\right]$

$$
\begin{aligned}
\mathrm{W}= & \frac{1}{13-2}\left[(28)^{2}+(54)^{2}+(42)^{2}+(20)^{2}+(226)^{2}+(257)^{2}+(207)^{2}+(180)^{2}\right. \\
& \left.+(178)^{2}+(137)^{2}+(37)^{2}+(1.4)^{2}+(1.5)^{2}-\frac{(28)^{2}}{1}-\frac{(1368.90)^{2}}{13-1}\right] \\
= & 9040.53
\end{aligned}
$$

\section{Eq. 3 :}

The zonation index, $R=\frac{B-W}{B}$

$$
\mathrm{R}=\frac{(6473-9041)}{6473}=-0.397 \approx 0.0
$$




\section{Part B:}

Sample calculation for flow unit correlation from well to well using six core well data

To perform the correlation of flow units between adjacent wells, the following steps have been performed in the following way.

(1) Rank well-zone means in order of decreasing magnitude of permeability

TABLE C.1: Rank of measured Core Permeability Means for six core wells in order of decreasing magnitude

\begin{tabular}{|c|c|c|c|c|}
\hline $\begin{array}{l}\text { Flow } \\
\text { Unit }\end{array}$ & Well Name & $\begin{array}{c}\text { Mean Core Perm } \\
(\mathbf{m D})\end{array}$ & $\begin{array}{c}\text { Number of Data } \\
\text { in Zone }\end{array}$ & Depth, ft \\
\hline 2 & Ball 18. & 197.50 & 6 & 2994-2999.75 \\
\hline 2 & P. Horner 11. & 170.00 & 3 & $3089.5-3092.5$ \\
\hline 2 & P. Horner 9. & 154.11 & 9 & $2896.5-2905.75$ \\
\hline 2 & Ball 19. & 145.20 & 5 & $3106-3110.75$ \\
\hline 1 & P. Horner 9. & 59.05 & 6 & $2891.75-2896.5$ \\
\hline 1 & Ball 18. & 36.00 & 4 & $2990.75-2994$ \\
\hline 1 & Ball 19. & 28.28 & 13 & $3086.25-3106$ \\
\hline 1 & P. Horner 11. & 23.03 & 4 & $3084.5-3089.5$ \\
\hline 3 & Ball 19. & 20.44 & 3 & $3110.75-3113.75$ \\
\hline 2 & T. Heirs 8. & 21.00 & 4 & $2793.5-2797.5$ \\
\hline 1 & Lemasters 13. & 17.13 & 4 & $3048.75-3052.75$ \\
\hline 3 & Ball 18. & 13.30 & 3 & $2999.75-3007.75$ \\
\hline 1 & T. Heirs 8. & 6.13 & 3 & $2791.50-2793.75$ \\
\hline 3 & P. Horner 11. & 3.60 & 1 & $3092.5-3093.25$ \\
\hline
\end{tabular}


(2) Calculattion of Eq. 2 using all permeability data in the entire reservoir.

$$
\begin{aligned}
\mathrm{W}= & \frac{1}{68-14}\left[(28)^{2}+(54)^{2}+(42)^{2}+\ldots \ldots \ldots \ldots+(238)^{2}+(192)^{2}+(3.6)^{2}\right. \\
& \left.\quad-\frac{(144)^{2}}{4}-\frac{(1185)^{2}}{6}-\frac{(39.9)^{2}}{3}-\ldots \ldots \ldots \ldots . . \frac{(510)^{2}}{3}-\frac{(3.6)^{2}}{1}\right] \\
= & 1042.026\left(\mathrm{mD}^{2}\right)
\end{aligned}
$$

(3) Calculate the standard deviation from Step 2.

$$
\begin{aligned}
& S=\sqrt{1042.026} \\
& =32.28(\mathrm{mD}) .
\end{aligned}
$$

(4) Select the z-values ${ }^{7}$ for a 99 percent probability level $\left(Z_{v, p}\right)$

$\begin{array}{llllllllllllll}\mathbf{P} & 2 & 3 & 4 & 5 & 6 & 7 & 8 & 9 & 10 & 11 & 12 & 13 & 14\end{array}$

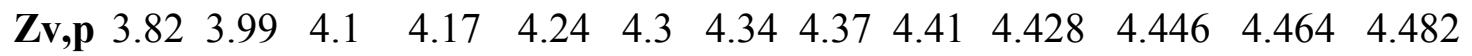

(5). Multiply the Z-values in Step 4 by the standard deviation in Step 3, e. $g$., $F_{p}{ }_{p}=S Z_{v, p}$

$\begin{array}{cccccccccccccc}\mathbf{P} & 2 & 3 & 4 & 5 & 6 & 7 & 8 & 9 & 10 & 11 & 12 & 13 & 14 \\ \mathbf{F}^{\prime} \mathbf{p} & 123.3 & 128.78 & 132.35 & 134.6 & 136.87 & 138.8 & 140.1 & 141.1 & 142.4 & 142.94 & 143.5 & 144.1 & 144.7\end{array}$

(6). Test the significant differences among well - flow unit means. First the largest mean is compared with each of the smaller means. In order for the means of Flow Unit 2 of Ball 18 and Flow Unit 3 of P. Horner 11 to be significantly different, 


$$
(197.50-3.6) \sqrt{\frac{2(6)(1)}{6+1}}=253.875
$$

must exceed $\mathrm{F}^{\prime}{ }_{14}=144.679$. It does; therefore, Flow Unit 2 of Ball 18 and Flow Unit 3 of P. Horner 11 represented by the means $197.50 \mathrm{md}$ and $3.60 \mathrm{md}$ are significantly different.

In order for the means of Flow Unit 2 of Ball 18 and Flow Unit 1 of $\mathrm{T}$. Heirs to be significantly different,

$$
(197.50-6.13) \sqrt{\frac{2(6)(3)}{6+3}}=382.74
$$

must exceed $\mathrm{F}_{13}^{\prime}=144.098$. Since it does, the well flow units (or the means) are significantly different.

TABLE C.2: Division of core permeability means into two zones.

\begin{tabular}{|c|l|c|c|c|c|}
\hline $\begin{array}{c}\text { Flow } \\
\text { Unit }\end{array}$ & \multicolumn{1}{|c|}{ Well } & $\begin{array}{c}\text { Core Perm } \\
(\mathbf{m D})\end{array}$ & $\begin{array}{c}\text { Number of Data } \\
\text { in Zone }\end{array}$ & F'p for 197.50 & F'p \\
\hline 2 & Ball 18. & 197.50 & 6 & 0.000 & \\
\hline 2 & P. Horner 11. & 170.00 & 3 & 55.000 & 123.310 \\
\hline 2 & P. Horner 9. & 154.11 & 9 & 116.428 & 128.797 \\
\hline 2 & Ball 19. & 145.20 & 5 & 122.146 & 132.348 \\
\hline \hline 1 & P. Horner 9. & 59.05 & 6 & 339.132 & 134.608 \\
\hline 1 & Ball 18. & 36.00 & 4 & 353.829 & 136.867 \\
\hline 1 & Ball 19. & 28.28 & 13 & 484.883 & 138.804 \\
\hline 1 & P. Horner 11. & 23.03 & 4 & 382.256 & 140.095 \\
\hline 3 & Ball 19. & 20.44 & 3 & 354.113 & 141.064 \\
\hline 2 & T. Heirs 8. & 21.00 & 4 & 386.692 & 142.355 \\
\hline 1 & Lemasters 13. & 17.13 & 4 & 395.171 & 142.936 \\
\hline 3 & Ball 18. & 13.30 & 3 & 368.400 & 143.517 \\
\hline 1 & T. Heirs 8. & 6.13 & 3 & 382.740 & 144.098 \\
\hline 3 & P. Horner 11. & 3.60 & 1 & 253.875 & 144.679 \\
\hline
\end{tabular}


Completing the test, it has been compared that the mean of flow unit 1 of $\mathrm{P}$. Horner 9 with the mean of the other Flow Units until the difference is not significant. It was found that comparisons are significant until flow unit 2 of Ball 19 is reached. At this point, another comparison was began to the next largest mean with the smaller mean as follows.

\begin{tabular}{|c|l|c|c|c|c|}
\hline $\begin{array}{c}\text { Flow } \\
\text { Unit }\end{array}$ & \multicolumn{1}{|c|}{ Well } & $\begin{array}{c}\text { Core Perm } \\
(\mathbf{m D})\end{array}$ & $\begin{array}{c}\text { Number of Data } \\
\text { in Zone }\end{array}$ & F'p for 59.05 & F'p \\
\hline 1 & P. Horner 9. & 59.05 & 6 & 0.000 & \\
\hline 1 & Ball 18. & 36.00 & 4 & 50.500 & 123.310 \\
\hline 1 & Ball 19. & 28.28 & 13 & 88.168 & 128.797 \\
\hline 1 & P. Horner 11. & 23.03 & 4 & 78.927 & 132.348 \\
\hline 3 & Ball 19. & 20.44 & 3 & 77.213 & 134.608 \\
\hline 2 & T. Heirs 8. & 21.00 & 4 & 83.363 & 136.867 \\
\hline 1 & Lemasters 13. & 17.13 & 4 & 91.842 & 138.804 \\
\hline 3 & Ball 18. & 13.30 & 3 & 91.500 & 140.095 \\
\hline 1 & T. Heirs 8. & 6.13 & 3 & 105.840 & 141.064 \\
\hline 3 & P. Horner 11. & 3.60 & 1 & 72.601 & 142.355 \\
\hline
\end{tabular}

$$
(59.05-3.6) \sqrt{\frac{2(6)(1)}{6+1}}=72.601<\mathrm{F}^{\prime}{ }_{10}(142.355)
$$

and so forth, rest of the differences are non significant and less than the values of corresponding F'p. So, these groups of flow units are significantly correlated with each other. 
Finally it has been distinguished that the means as separate groups, which are not significantly different as follows.

TABLE C.3: Final division of core permeability means into two different groups.

\section{Group One}

$\begin{array}{lcl}\text { Well } & \text { Flow Unit } & \text { Depth, } \mathbf{f t} \\ \text { Ball 18. } & 2 & 2994-2999.75 \\ \text { P. Horner 11. } & 2 & 3089.5-3092.5 \\ \text { P. Horner 9. } & 2 & 2896.5-2905.75 \\ \text { Ball 19. } & 2 & 3106-3110.75\end{array}$

\section{$\underline{\text { Group Two }}$} Well Unit Depth, ft

P. Horner 9. $\quad 1 \quad$ 2891.75-2896.5 Ball 18. $\quad 1 \quad 2990.75-2994$

Ball 19. $\quad 1 \quad 3086.25-3106$

P. Horner 11. 1 3084.5-3089.5 Ball 19. $\quad 3 \quad 3110.75-3113.75$

T. Heirs 8. 2 2793.5-2797.5

Lemasters 13. $13048.75-3052.75$

Ball 18. $\quad 3 \quad 2999.75-3007.75$

T. Heirs 8. $\quad 1 \quad 2791.50-2793.75$

P. Horner 11. 3 3092.5-3093.25 


\section{APPENDIX D.}

Determination of Flow Unit with Core Permeability by Statistical Method in the Cored Wells 
Table D.1 Flow Unit calculation for F. R. Ball 18 into two zones

$\begin{array}{cccccccc}\begin{array}{c}\text { Sample No. } \\ \text { per Group }\end{array} & \begin{array}{c}\text { Core } \\ \text { Depth }\end{array} & \begin{array}{c}\text { Core } \\ \text { perm. } \\ (\mathrm{mD})\end{array} & \begin{array}{c}\text { Cum. Sum of } \\ \text { Permeability }\end{array} & \begin{array}{c}\text { Grand Sum } \\ \text { Minus } \\ \text { Cum Sum } \\ (\mathrm{mD})\end{array} & \begin{array}{c}\mathrm{B} \\ \left(\mathrm{mD}^{2}\right)\end{array} & \begin{array}{c}\mathrm{W} \\ \left(\mathrm{mD}^{2}\right)\end{array} & \begin{array}{c}\text { Zonation } \\ \text { Index, } \mathrm{R}\end{array} \\ 1 & 2990.75 & 28.000 & 28.000 & 1340.90 & 6473.231 & 9040.528 & 0.00 \\ 2 & 2991.50 & 54.000 & 82.000 & 1286.90 & 9772.431 & 8740.601 & 0.11 \\ 3 & 2993.50 & 42.000 & 124.000 & 1244.90 & 15957.764 & 8178.298 & 0.49 \\ 4 & 2994.00 & 20.000 & 144.000 & 1224.90 & 27747.720 & 7106.484 & 0.74 \\ 5 & 2995.50 & 226.000 & 370.000 & 998.90 & 7959.981 & 8905.369 & 0.00 \\ 6 & 2996.25 & 257.000 & 627.000 & 741.90 & 7.131 & 9628.355 & 0.00 \\ 7 & 2997.50 & 207.000 & 834.000 & 534.90 & 2906.308 & 9364.794 & 0.00 \\ 8 & 2998.25 & 180.000 & 1014.000 & 354.90 & 9570.132 & 8758.992 & 0.08 \\ 9 & 2999.00 & 178.000 & 1192.000 & 176.90 & 21552.010 & 7669.730 & 0.64 \\ 10 & 2999.75 & 137.000 & 1329.000 & 39.90 & 33009.600 & 6628.131 & 0.80 \\ * * & * * & * * & * * & * * & & * & * \\ 11 & 3002.75 & 37.000 & 1366.000 & 2.90 & 25491.399 & 7311.604 & 0.71 \\ 12 & 3007.25 & 1.400 & 1367.400 & 1.50 & 11672.310 & 8567.885 & 0.27 \\ 13 & 3007.75 & 1.500 & 1368.900 & 0.00 & - & - & -\end{array}$

Table D.2 Flow Unit calculation for F. R. Ball 18 into three zones

\begin{tabular}{|c|c|c|c|c|c|c|c|}
\hline $\begin{array}{l}\text { Sample No. } \\
\text { per Group }\end{array}$ & Core Depth & $\begin{array}{l}\text { Core perm. } \\
\text { (mD) }\end{array}$ & $\begin{array}{l}\text { Cum. Sum of } \\
\text { Permeability }\end{array}$ & $\begin{array}{l}\text { Grand Sum } \\
\text { Minus } \\
\text { Cum Sum (mD) }\end{array}$ & $\begin{array}{l}\text { B } \\
\left(m D^{2}\right)\end{array}$ & $\begin{array}{l}W \\
\left(m D^{2}\right)\end{array}$ & $\begin{array}{l}\text { Zonation } \\
\text { Index, R }\end{array}$ \\
\hline \multicolumn{8}{|l|}{ GROUP 1} \\
\hline 1 & 2990.75 & 28 & 28 & 1301 & 22618.14 & 6068.28 & 0.732 \\
\hline 2 & 2991.5 & 54 & 82 & 1247 & 27061.81 & 5179.54 & 0.809 \\
\hline 3 & 2993.5 & 42 & 124 & 1205 & 34471.49 & 3697.61 & 0.893 \\
\hline 4 & 2994 & 20 & 144 & 1185 & 47803.5 & 1031.20 & 0.987 \\
\hline ** & $* *$ & $* *$ & $* *$ & $* *$ & $* *$ & $* *$ & $* *$ \\
\hline 5 & 2995.5 & 226 & 370 & 959 & 33850.85 & 3821.73 & 0.887 \\
\hline 6 & 2996.25 & 257 & 627 & 702 & 22554 & 6081.10 & 0.730 \\
\hline 7 & 2997.5 & 207 & 834 & 495 & 18712.82 & 6849.34 & 0.634 \\
\hline 8 & 2998.25 & 180 & 1014 & 315 & 17261.25 & 7139.65 & 0.586 \\
\hline 9 & 2999 & 178 & 1192 & 137 & 16514.14 & 7289.08 & 0.559 \\
\hline 10 & 2999.75 & 137 & 1329 & 0 & -- & -- & -- \\
\hline \multicolumn{8}{|l|}{ GROUP 2} \\
\hline 1 & 3002.75 & 37 & 37 & 2.9 & 16926.07 & 7206.69 & 0.574 \\
\hline 2 & 3007.25 & 1.4 & 38.4 & 1.5 & 16609.23 & 7270.06 & 0.562 \\
\hline \multirow[t]{2}{*}{3} & 3007.75 & 1.5 & 39.9 & 0 & -- & -- & -- \\
\hline & SUM & 1368.9 & & & & & \\
\hline
\end{tabular}


Table D.3 Flow Unit calculation for F. R. Ball 18 into four zones

\begin{tabular}{|c|c|c|c|c|c|c|c|}
\hline $\begin{array}{l}\text { Sample No. } \\
\text { per Group }\end{array}$ & $\begin{array}{l}\text { Core Depth } \\
\mathrm{ft}\end{array}$ & $\begin{array}{l}\text { Core perm. } \\
(\mathrm{mD})\end{array}$ & $\begin{array}{l}\text { Cum. Sum of } \\
\text { Permeability }\end{array}$ & $\begin{array}{l}\text { Grand Sum } \\
\text { Minus } \\
\text { Cum Sum (mD) }\end{array}$ & $\begin{array}{l}B \\
\left(m D^{2}\right)\end{array}$ & $\begin{array}{l}W \\
\left(m^{2}\right)\end{array}$ & $\begin{array}{l}\text { Zonation } \\
\text { Index, R }\end{array}$ \\
\hline \multicolumn{8}{|l|}{ GROUP 1} \\
\hline 1 & 2990.75 & 28 & 28 & 116 & 31897.4 & 1136.3 & 0.964 \\
\hline 2 & 2991.5 & 54 & 82 & 62 & 31902.3 & 1134.7 & 0.964 \\
\hline 3 & 2993.5 & 42 & 124 & 20 & 31982.8 & 1107.9 & 0.965 \\
\hline 4 & 2994 & 20 & 144 & 0 & -- & -- & -- \\
\hline \multicolumn{8}{|l|}{ GROUP 2} \\
\hline$\overline{1}$ & 2995.5 & 226 & 226 & 959 & 32193.9 & 1037.5 & 0.968 \\
\hline 2 & 2996.25 & 257 & 483 & 702 & 33805.0 & 500.4 & 0.985 \\
\hline 3 & 2997.5 & 207 & 690 & 495 & 33981.5 & 441.6 & 0.987 \\
\hline 4 & 2998.25 & 180 & 870 & 315 & 33469.0 & 612.4 & 0.982 \\
\hline 5 & 2999 & 178 & 1048 & 137 & 33333.1 & 657.7 & 0.980 \\
\hline 6 & 2999.75 & 137 & 1185 & 0 & -- & -- & -- \\
\hline \multicolumn{8}{|l|}{ GROUP 3} \\
\hline 1 & 3002.75 & 37 & 37 & 2.9 & 32149.8 & 1052.2 & 0.967 \\
\hline 2 & 3007.25 & 1.4 & 38.4 & 1.5 & 31938.6 & 1122.6 & 0.965 \\
\hline \multirow[t]{2}{*}{3} & 3007.75 & 1.5 & 39.9 & 0 & -- & -- & -- \\
\hline & SUM & 1368.9 & & & & & \\
\hline
\end{tabular}


Table D.4 Flow Unit calculation for F. R. Ball 19 into two zones

$\begin{array}{cccccccc}\begin{array}{c}\text { Sample No. } \\ \text { per Group }\end{array} & \begin{array}{c}\text { Core } \\ \text { Depth }\end{array} & \begin{array}{c}\text { Core } \\ \text { perm. } \\ (\mathrm{mD})\end{array} & \begin{array}{c}\text { Cum. Sum of } \\ \text { Permeability }\end{array} & \begin{array}{c}\text { Grand Sum } \\ \text { Minus } \\ \text { Cum Sum } \\ (\mathrm{mD})\end{array} & \begin{array}{c}\mathrm{B} \\ \left(\mathrm{mD}^{2}\right)\end{array} & \begin{array}{c}\mathrm{W} \\ \left(\mathrm{mD}^{2}\right)\end{array} & \begin{array}{c}\text { Zonation } \\ \text { Index, } \mathrm{R}\end{array} \\ 1 & 3086.25 & 2.44 & 2.44 & 1152.52 & 2900.471 & 3527.636 & 0.00 \\ 2 & 3092.25 & 4.24 & 6.68 & 1148.28 & 5898.919 & 3369.823 & 0.43 \\ 3 & 3092.75 & 11 & 17.68 & 1137.28 & 8439.472 & 3236.109 & 0.62 \\ 4 & 3094.25 & 38 & 55.68 & 1099.28 & 8337.790 & 3241.461 & 0.61 \\ 5 & 3094.75 & 31 & 86.68 & 1068.28 & 9308.469 & 3190.373 & 0.66 \\ 6 & 3099.25 & 17 & 103.68 & 1051.28 & 11950.300 & 3051.329 & 0.74 \\ 7 & 3100 & 41 & 144.68 & 1010.28 & 12374.420 & 3029.007 & 0.76 \\ 8 & 3101.25 & 65 & 209.68 & 945.28 & 10710.057 & 3116.605 & 0.71 \\ 9 & 3102 & 17 & 226.68 & 928.28 & 13997.360 & 2943.589 & 0.79 \\ 10 & 3103 & 6.79 & 233.47 & 921.49 & 19125.117 & 2673.707 & 0.86 \\ 11 & 3104 & 73 & 306.47 & 848.49 & 17011.461 & 2784.952 & 0.84 \\ 12 & 3105 & 60 & 366.47 & 788.49 & 16750.697 & 2798.676 & 0.83 \\ 13 & 3106 & 1.16 & 367.63 & 787.33 & 24361.760 & 2398.094 & 0.90 \\ * * & * * & * * & * * & * * & * * & * * & * * \\ 14 & 3107.25 & 110 & 477.63 & 677.33 & 18313.848 & 2716.405 & 0.85 \\ 15 & 3108 & 106 & 583.63 & 571.33 & 13590.660 & 2964.994 & 0.78 \\ 16 & 3108.75 & 207 & 790.63 & 364.33 & 2095.157 & 3570.021 & 0.00 \\ 17 & 3109.5 & 179 & 969.63 & 185.33 & 371.045 & 3660.763 & 0.00 \\ 18 & 3110.75 & 124 & 1093.63 & 61.33 & 4179.110 & 3460.339 & 0.17 \\ 19 & 3112 & 26 & 1119.63 & 35.33 & 3080.943 & 3518.137 & 0.00 \\ 20 & 3112.5 & 34 & 1153.63 & 1.33 & 3024.278 & 3521.120 & 0.00 \\ 21 & 3113.75 & 1.33 & 1154.96 & 0 & -- & - & --\end{array}$


Table D.5 Flow Unit calculation for F. R. Ball 19 into three zones

\begin{tabular}{|c|c|c|c|c|c|c|c|}
\hline $\begin{array}{l}\text { Sample No. } \\
\text { per Group }\end{array}$ & $\begin{array}{l}\text { Core } \\
\text { Depth }\end{array}$ & $\begin{array}{l}\text { Core } \\
\text { perm. } \\
(\mathrm{mD})\end{array}$ & $\begin{array}{l}\text { Cum. Sum of } \\
\text { Permeability }\end{array}$ & $\begin{array}{l}\text { Grand Sum } \\
\text { Minus } \\
\text { Cum Sum } \\
\text { (mD) }\end{array}$ & $\begin{array}{c}\mathrm{B} \\
\left(\mathrm{mD}^{2}\right)\end{array}$ & $\begin{array}{c}W \\
\left(m D^{2}\right)\end{array}$ & $\begin{array}{l}\text { Zonation } \\
\text { Index, R }\end{array}$ \\
\hline 1 & 3086.25 & 2.44 & 2.44 & 365.19 & 12542.532 & 2491.138 & 0.80 \\
\hline 2 & 3092.25 & 4.24 & 6.68 & 360.95 & 12915.930 & 2449.649 & 0.81 \\
\hline 3 & 3092.75 & 11 & 17.68 & 349.95 & 13158.080 & 2422.744 & 0.82 \\
\hline 4 & 3094.25 & 38 & 55.68 & 311.95 & 12776.533 & 2465.138 & 0.81 \\
\hline 5 & 3094.75 & 31 & 86.68 & 280.95 & 12667.382 & 2477.266 & 0.80 \\
\hline 6 & 3099.25 & 17 & 103.68 & 263.95 & 12854.928 & 2456.427 & 0.81 \\
\hline 7 & 3100 & 41 & 144.68 & 222.95 & 12620.123 & 2482.517 & 0.80 \\
\hline 8 & 3101.25 & 65 & 209.68 & 157.95 & 12225.410 & 2526.374 & 0.79 \\
\hline 9 & 3102 & 17 & 226.68 & 140.95 & 12320.753 & 2515.780 & 0.80 \\
\hline 10 & 3103 & 6.79 & 233.47 & 134.16 & 12707.963 & 2472.757 & 0.81 \\
\hline 11 & 3104 & 73 & 306.47 & 61.16 & 12187.136 & 2530.627 & 0.79 \\
\hline 12 & 3105 & 60 & 366.47 & 1.16 & 12579.250 & 2487.058 & 0.80 \\
\hline 13 & 3106 & 1.16 & 367.63 & 0 & -- & -- & -- \\
\hline$* *$ & $* *$ & $* *$ & $* *$ & ** & ** & ** & ** \\
\hline 1 & 3107.25 & 110 & 110 & 677.33 & 12257.556 & 2522.802 & 0.79 \\
\hline 2 & 3108 & 106 & 216 & 571.33 & 12303.344 & 2517.715 & 0.80 \\
\hline 3 & 3108.75 & 207 & 423 & 364.33 & 16532.982 & 2047.755 & 0.88 \\
\hline 4 & 3109.5 & 179 & 602 & 185.33 & 23031.748 & 1325.670 & 0.94 \\
\hline 5 & 3110.75 & 124 & 726 & 61.33 & 26772.342 & 910.048 & 0.97 \\
\hline ** & $* *$ & $* *$ & $* *$ & $* *$ & $* *$ & $* *$ & $* *$ \\
\hline 6 & 3112 & 26 & 752 & 35.33 & 20875.232 & 1565.283 & 0.93 \\
\hline 7 & 3112.5 & 34 & 786 & 1.33 & 17567.017 & 1932.862 & 0.89 \\
\hline 8 & 3113.75 & 1.33 & 787.33 & 0 & -- & -- & -- \\
\hline
\end{tabular}

Table D.6 Flow Unit calculation for Lemasters 13 into two zones

$\begin{array}{cccccccc}\begin{array}{c}\text { Sample No. } \\ \text { per Group }\end{array} & \begin{array}{c}\text { Core } \\ \text { Depth }\end{array} & \begin{array}{c}\text { Core } \\ \text { perm. } \\ (\mathrm{mD})\end{array} & \begin{array}{c}\text { Cum. Sum of } \\ \text { Permeability }\end{array} & \begin{array}{c}\text { Grand Sum } \\ \text { Minus } \\ \text { Cum Sum } \\ (\mathrm{mD})\end{array} & \begin{array}{c}\mathrm{B} \\ \left(\mathrm{mD}^{2}\right)\end{array} & \begin{array}{c}\mathrm{W} \\ \left(\mathrm{mD}^{2}\right)\end{array} & \begin{array}{c}\text { Zonation } \\ \text { Index, R }\end{array} \\ \frac{1}{2} & 3,048.75 & 37.000 & 37.00 & 31.51 & 527 & 77 & 0.85 \\ 3 & 3,050.00 & 1.510 & 38.51 & 30.00 & 18 & 331 & 0.00 \\ 4 & 3,052.25 & 19.000 & 57.51 & 11.00 & 50 & 315 & 0.00 \\ & 3,052.75 & 11.000 & 68.51 & 0.00 & -- & -- & --\end{array}$


Table D.7 Flow Unit calculation for T. Heirs 8 into two zones

$\begin{array}{cccccccc}\begin{array}{c}\text { Sample No. } \\ \text { per Group }\end{array} & \begin{array}{c}\text { Core } \\ \text { Depth }\end{array} & \begin{array}{c}\text { Core } \\ \text { perm. } \\ (\mathrm{mD})\end{array} & \begin{array}{c}\text { Cum. Sum of } \\ \text { Permeability }\end{array} & \begin{array}{c}\text { Grand Sum Minus } \\ \text { Cum Sum }(\mathrm{mD})\end{array} & \begin{array}{c}\mathrm{B} \\ \left(\mathrm{mD}^{2}\right)\end{array} & \begin{array}{c}\text { W } \\ \left(\mathrm{mD}^{2}\right)\end{array} & \begin{array}{c}\text { Zonation } \\ \text { Index, R }\end{array} \\ 1 & 2,791.50 & 6.500 & 6.5 & 95.9 & 77.086 & 65.050 & 0.16 \\ 2 & 2,792.50 & 3.800 & 10.3 & 92.1 & 251.561 & 30.155 & 0.88 \\ 3 & 2,793.75 & 8.100 & 18.4 & 84 & 378.888 & 4.689 & 0.99 \\ * * & * * & * * & * * & * * & * 6 & * & * * \\ 4 & 2,794.75 & 18.000 & 36.4 & 66 & 285.274 & 23.412 & 0.92 \\ 5 & 2,795.25 & 22.000 & 58.4 & 44 & 152.146 & 50.038 & 0.67 \\ 6 & 2,796.00 & 23.000 & 81.4 & 21 & 47.361 & 70.995 & -0.50 \\ 7 & 2,797.50 & 21.000 & 102.400 & 0.00 & -- & - & --\end{array}$

Table D.8 Flow Unit calculation for P. Horner 9 into two zones

\begin{tabular}{|c|c|c|c|c|c|c|c|}
\hline $\begin{array}{l}\text { Sample No. } \\
\text { per Group }\end{array}$ & $\begin{array}{l}\text { Core } \\
\text { Depth }\end{array}$ & $\begin{array}{l}\text { Core } \\
\text { perm. } \\
(\mathrm{mD})\end{array}$ & $\begin{array}{l}\text { Cum. Sum of } \\
\text { Permeability }\end{array}$ & $\begin{array}{c}\text { Grand Sum Minus } \\
\text { Cum Sum (mD) }\end{array}$ & $\begin{array}{c}B \\
\left(m D^{2}\right)\end{array}$ & $\begin{array}{c}W \\
\left(m D^{2}\right)\end{array}$ & $\begin{array}{l}\text { Zonation } \\
\text { Index, R }\end{array}$ \\
\hline 1 & 2891.75 & 3.3 & 3.3 & 1738 & 13629.46 & 2558.13 & 0.81 \\
\hline 2 & 2893 & 40 & 43.3 & 1698 & 20580.66 & 2023.42 & 0.90 \\
\hline 3 & 2893.5 & 55 & 98.3 & 1643 & 26033.33 & 1603.99 & 0.94 \\
\hline 4 & 2895 & 92 & 190.3 & 1551 & 25602.81 & 1637.11 & 0.94 \\
\hline 5 & 2895.75 & 80 & 270.3 & 1471 & 28854.81 & 1386.95 & 0.95 \\
\hline 6 & 2896.5 & 84 & 354.3 & 1387 & 32531.81 & 1104.10 & 0.97 \\
\hline ** & $\star *$ & $* *$ & $\star *$ & $* *$ & $\star *$ & $* *$ & $* *$ \\
\hline 7 & 2898.25 & 123 & 477.3 & 1264 & 30115.33 & 1289.99 & 0.96 \\
\hline 8 & 2898.75 & 136 & 613.3 & 1128 & 26644.54 & 1556.97 & 0.94 \\
\hline 9 & 2900 & 160 & 773.3 & 968 & 20472.61 & 2031.74 & 0.90 \\
\hline 10 & 2901 & 135 & 908.3 & 833 & 19136.98 & 2134.48 & 0.89 \\
\hline 11 & 2902 & 144 & 1052.3 & 689 & 17205.38 & 2283.06 & 0.87 \\
\hline 12 & 2903 & 124 & 1176.3 & 565 & 19573.43 & 2100.90 & 0.89 \\
\hline 13 & 2903.5 & 148 & 1324.3 & 417 & 19708.21 & 2090.54 & 0.89 \\
\hline 14 & 2905.25 & 203 & 1527.3 & 214 & 10271.81 & 2816.41 & 0.73 \\
\hline 15 & 2905.75 & 214 & 1741.3 & 0 & - & -- & -- \\
\hline
\end{tabular}


Table D.9 Flow Unit calculation for P. Horner 11 into two zones

\begin{tabular}{|c|c|c|c|c|c|c|c|}
\hline $\begin{array}{l}\text { Sample No. } \\
\text { per Group }\end{array}$ & $\begin{array}{l}\text { Core } \\
\text { Depth }\end{array}$ & $\begin{array}{l}\text { Core } \\
\text { perm. } \\
\text { (mD) }\end{array}$ & $\begin{array}{l}\text { Cum. Sum of } \\
\text { Permeability }\end{array}$ & $\begin{array}{l}\text { Grand Sum Minus } \\
\text { Cum Sum (mD) }\end{array}$ & $\begin{array}{c}\mathrm{B} \\
\left(\mathrm{mD}^{2}\right)\end{array}$ & $\begin{array}{c}W \\
\left(m^{2}\right)\end{array}$ & $\begin{array}{l}\text { Zonation } \\
\text { Index, R }\end{array}$ \\
\hline 1 & $3,084.50$ & 2.100 & 2.100 & 603.60 & 6192.914 & 8550.232 & 0.00 \\
\hline 2 & $3,085.25$ & 18.000 & 20.100 & 585.60 & 11497.504 & 7666.134 & 0.33 \\
\hline 3 & $3,088.75$ & 20.000 & 40.100 & 565.60 & 18657.614 & 6472.782 & 0.65 \\
\hline 4 & $3,089.50$ & 52.000 & 92.100 & 513.60 & 22207.781 & 5881.088 & 0.75 \\
\hline ** & $* *$ & $* *$ & $* *$ & $* *$ & $* *$ & $* *$ & $* *$ \\
\hline 5 & $3,090.50$ & 80.000 & 172.100 & 433.60 & 22734.274 & 5793.339 & 0.75 \\
\hline 6 & $3,092.00$ & 238.000 & 410.100 & 195.60 & 1300.954 & 9365.559 & 0.00 \\
\hline 7 & $3,092.50$ & 192.000 & 602.100 & 3.60 & 5943.100 & 8591.868 & 0.00 \\
\hline 8 & $3,093.25$ & 3.600 & 605.700 & 0.00 & -- & -- & -- \\
\hline
\end{tabular}

Table D.10 Flow Unit calculation for P. Horner 11 into three zones

\begin{tabular}{|c|c|c|c|c|c|c|c|}
\hline $\begin{array}{l}\text { Sample No. } \\
\text { per Group }\end{array}$ & $\begin{array}{l}\text { Core } \\
\text { Depth }\end{array}$ & $\begin{array}{l}\text { Core } \\
\text { perm. } \\
(\mathrm{mD})\end{array}$ & $\begin{array}{l}\text { Cum. Sum of } \\
\text { Permeability }\end{array}$ & $\begin{array}{l}\text { Grand Sum Minus } \\
\text { Cum Sum (mD) }\end{array}$ & $\begin{array}{c}B \\
\left(m^{2}\right)\end{array}$ & $\begin{array}{c}W \\
\left(m D^{2}\right)\end{array}$ & $\begin{array}{l}\text { Zonation } \\
\text { Index, R }\end{array}$ \\
\hline 1 & $3,084.50$ & 2.100 & 2.100 & 90.00 & 11395.794 & 6940.544 & 0.39 \\
\hline 2 & $3,085.25$ & 18.000 & 20.100 & 72.00 & 11440.592 & 6922.625 & 0.39 \\
\hline 3 & 3088.75 & 20 & 40.1 & 52 & 11663.591 & 6833.425 & 0.41 \\
\hline 4 & 3089.5 & 52 & 92.1 & 0 & -- & -- & -- \\
\hline ** & $* *$ & ** & $* *$ & ** & $* *$ & ** & $* *$ \\
\hline 1 & 3090.5 & 80 & 80 & 433.6 & 12665.597 & 6432.623 & 0.49 \\
\hline 2 & 3092 & 238 & 318 & 195.6 & 12976.611 & 6308.218 & 0.51 \\
\hline 3 & 3092.5 & 192 & 510 & 3.6 & 21487.251 & 2903.962 & 0.86 \\
\hline$* *$ & $* *$ & $* *$ & $* *$ & $* *$ & $* *$ & $* *$ & $* *$ \\
\hline 4 & 3093.25 & 3.6 & 513.6 & 0 & -- & -- & -- \\
\hline
\end{tabular}




\section{APPENDIX E.}

Determination of Flow Unit with Predicted Permeability by Statistical Method 
Table E.1 Flow Unit calculation for Predicted Permeability into two zones for F. R. Ball 18

\begin{tabular}{|c|c|c|c|c|c|c|c|c|}
\hline $\begin{array}{l}\text { Sample No. } \\
\text { per Group }\end{array}$ & $\begin{array}{l}\text { Mid Point } \\
\text { Depth } \\
\mathrm{ft}\end{array}$ & $\begin{array}{c}\text { Average } \\
\text { Log } \\
\text { Density }\end{array}$ & $\begin{array}{l}\text { Predicted } \\
\text { Perm. }\end{array}$ & $\begin{array}{l}\text { Cum. Sum of } \\
\text { Permeability }\end{array}$ & $\begin{array}{c}\text { Grand Sum } \\
\text { Minus } \\
\text { Cum Sum } \\
\text { (mD) }\end{array}$ & $\begin{array}{c}B \\
\left(m D^{2}\right)\end{array}$ & $\begin{array}{c}W \\
\left(m D^{2}\right)\end{array}$ & $\begin{array}{l}\text { Zonation } \\
\text { Index, R }\end{array}$ \\
\hline 1 & 2990.50 & 2.426 & 18.835 & 18.83 & 796.22 & 900.32 & 3954.44 & 0.00 \\
\hline 2 & 2991.5 & 2.399 & 28.012 & 46.85 & 768.21 & 1362.87 & 3923.61 & 0.00 \\
\hline 3 & 2992.5 & 2.435 & 16.581 & 63.43 & 751.63 & 2616.76 & 3840.02 & 0.00 \\
\hline 4 & 2993.5 & 2.459 & 11.562 & 74.99 & 740.06 & 4458.98 & 3717.20 & 0.17 \\
\hline$\underline{5}$ & 2994.5 & 2.432 & 17.133 & 92.12 & 722.93 & 6172.47 & 3602.97 & 0.42 \\
\hline 6 & 2995.5 & 2.340 & 65.440 & 157.56 & 657.49 & 4359.88 & 3723.81 & 0.15 \\
\hline 7 & 2996.50 & 2.271 & 180.098 & 337.66 & 477.392 & 1.022 & 4014.40 & 0.00 \\
\hline 8 & 2997.50 & 2.272 & 177.493 & 515.16 & 299.899 & 4089.12 & 3741.86 & 0.08 \\
\hline 9 & 2998.50 & 2.286 & 144.223 & 659.38 & 155.676 & 12261.0 & 3197.07 & 0.74 \\
\hline 10 & 2999.50 & 2.321 & 86.937 & 746.32 & 68.739 & 17296.4 & 2861.37 & 0.83 \\
\hline ** & $* *$ & $* *$ & $* *$ & $* *$ & $* *$ & $* *$ & $* *$ & $* *$ \\
\hline 11 & 3000.50 & 2.415 & 22.108 & 768.42 & 46.631 & 14964.6 & 3016.82 & 0.80 \\
\hline 12 & 3001.50 & 2.487 & 7.690 & 776.11 & 38.941 & 11422.0 & 3253.00 & 0.72 \\
\hline 13 & 3002.50 & 2.460 & 11.395 & 787.51 & 27.546 & 8817.74 & 3426.62 & 0.61 \\
\hline 14 & 3003.50 & 2.480 & 8.577 & 796.09 & 18.969 & 6310.67 & 3593.75 & 0.43 \\
\hline 15 & 3004.50 & 2.507 & 5.809 & 801.89 & 13.159 & 3878.34 & 3755.91 & 0.03 \\
\hline 16 & 3005.50 & 2.506 & 5.852 & 807.75 & 7.308 & 1754.55 & 3897.50 & 0.00 \\
\hline 17 & 3006.50 & 2.491 & 7.307 & 815.05 & 0.000 & -- & -- & -- \\
\hline
\end{tabular}

Table E.2 Flow Unit calculation for Predicted Permeability into three zones for F. R. Ball 18

\begin{tabular}{|c|c|c|c|c|c|c|c|c|}
\hline $\begin{array}{l}\text { Sample No. } \\
\text { per Group }\end{array}$ & $\begin{array}{l}\text { Mid Point } \\
\text { Depth } \\
\mathrm{ft}\end{array}$ & $\begin{array}{l}\text { Average } \\
\text { Log } \\
\text { Density }\end{array}$ & $\begin{array}{l}\text { Predicted } \\
\text { Perm. }\end{array}$ & $\begin{array}{l}\text { Cum. Sum of } \\
\text { Permeability }\end{array}$ & $\begin{array}{l}\text { Grand Sum } \\
\text { Minus } \\
\text { Cum Sum } \\
\text { (mD) }\end{array}$ & $\begin{array}{c}B \\
\left(m D^{2}\right)\end{array}$ & $\begin{array}{c}W \\
\left(m D^{2}\right)\end{array}$ & $\begin{array}{l}\text { Zonation } \\
\text { Index, R }\end{array}$ \\
\hline 1 & 2990.50 & 2.426 & 18.835 & 18.83 & 727.480 & 10377.8 & 2818.67 & 0.73 \\
\hline 2 & 2991.50 & 2.399 & 28.012 & 46.85 & 699.468 & 11926.0 & 2597.50 & 0.78 \\
\hline 3 & 2992.50 & 2.435 & 16.581 & 63.43 & 682.887 & 14779.0 & 2189.93 & 0.85 \\
\hline 4 & 2993.50 & 2.459 & 11.562 & 74.99 & 671.325 & 19058.2 & 1578.61 & 0.92 \\
\hline 5 & 2994.50 & 2.432 & 17.133 & 92.12 & 654.191 & 24444.2 & 809.19 & 0.97 \\
\hline 6 & 2995.50 & 2.340 & 65.440 & 157.56 & 588.751 & 26196.2 & 558.89 & 0.98 \\
\hline ** & $* *$ & $* *$ & $* *$ & $* *$ & $* *$ & ** & $* *$ & $* *$ \\
\hline 7 & 2996.50 & 2.271 & 180.098 & 337.66 & 408.653 & 16775.8 & 1904.68 & 0.89 \\
\hline 8 & 2997.50 & 2.272 & 177.493 & 515.16 & 231.160 & 10744.2 & 2766.33 & 0.74 \\
\hline 9 & 2998.50 & 2.286 & 144.223 & 659.38 & 86.937 & 8732.31 & 3053.74 & 0.65 \\
\hline 10 & 2999.50 & 2.321 & 86.937 & 746.32 & 0.000 & -- & -- & -- \\
\hline ** & $* *$ & ** & $* *$ & ** & $* *$ & ** & ** & ** \\
\hline 1 & 3000.50 & 2.415 & 22.108 & 22.11 & 46.631 & 8736.27 & 3053.17 & 0.65 \\
\hline 2 & 3001.50 & 2.487 & 7.690 & 29.80 & 38.941 & 8684.30 & 3060.60 & 0.65 \\
\hline 3 & 3002.50 & 2.460 & 11.395 & 41.19 & 27.546 & 8688.34 & 3060.02 & 0.65 \\
\hline 4 & 3003.50 & 2.480 & 8.577 & 49.77 & 18.969 & 8680.29 & 3061.17 & 0.65 \\
\hline 5 & 3004.50 & 2.507 & 5.809 & 55.58 & 13.160 & 8662.89 & 3063.66 & 0.65 \\
\hline 6 & 3005.50 & 2.506 & 5.852 & 61.43 & 7.308 & 8651.87 & 3065.23 & 0.65 \\
\hline 7 & 3006.50 & 2.491 & 7.307 & 68.74 & 0.000 & -- & -- & -- \\
\hline
\end{tabular}


Table E.3 Flow Unit calculation for Predicted Permeability into two zones for F. R. Ball 19

\begin{tabular}{|c|c|c|c|c|c|c|c|c|}
\hline $\begin{array}{l}\text { Sample No. } \\
\text { per Group }\end{array}$ & $\begin{array}{l}\text { Mid Point } \\
\text { Depth } \\
\mathrm{ft}\end{array}$ & $\begin{array}{c}\text { Average } \\
\text { Log } \\
\text { Density }\end{array}$ & $\begin{array}{l}\text { Predicted } \\
\text { Perm. }\end{array}$ & $\begin{array}{l}\text { Cum. Sum of } \\
\text { Permeability }\end{array}$ & $\begin{array}{l}\text { Grand Sum } \\
\text { Minus } \\
\text { Cum Sum } \\
\text { (mD) }\end{array}$ & $\begin{array}{c}B \\
\left(m D^{2}\right)\end{array}$ & $\begin{array}{c}W \\
\left(m D^{2}\right)\end{array}$ & $\begin{array}{l}\text { Zonation } \\
\text { Index, R }\end{array}$ \\
\hline 1 & 3086.5 & 2.648 & 0.521 & 0.521 & 1127.83 & 1640.87 & 2680.10 & 0.00 \\
\hline 2 & 3087.5 & 2.601 & 1.113 & 1.634 & 1126.72 & 3357.36 & 2614.08 & 0.22 \\
\hline 3 & 3088.5 & 2.573 & 1.748 & 3.382 & 1124.97 & 5155.44 & 2544.93 & 0.51 \\
\hline 4 & 3089.5 & 2.566 & 1.959 & 5.341 & 1123.01 & 7084.52 & 2470.73 & 0.65 \\
\hline 5 & 3090.5 & 2.549 & 2.583 & 7.924 & 1120.43 & 9122.70 & 2392.34 & 0.74 \\
\hline 6 & 3091.5 & 2.515 & 4.526 & 12.451 & 1115.90 & 11156.8 & 2314.10 & 0.79 \\
\hline 7 & 3092.5 & 2.489 & 6.908 & 19.359 & 1108.99 & 13147.9 & 2237.52 & 0.83 \\
\hline 8 & 3093.5 & 2.455 & 12.057 & 31.417 & 1096.94 & 14816.1 & 2173.36 & 0.85 \\
\hline 9 & 3094.5 & 2.430 & 18.032 & 49.449 & 1078.90 & 16065.9 & 2125.29 & 0.87 \\
\hline 10 & 3095.5 & 2.425 & 19.480 & 68.929 & 1059.42 & 17358.8 & 2075.57 & 0.88 \\
\hline 11 & 3096.5 & 2.491 & 6.687 & 75.616 & 1052.74 & 20240.5 & 1964.73 & 0.90 \\
\hline 12 & 3097.5 & 2.512 & 4.772 & 80.388 & 1047.96 & 23707.2 & 1831.40 & 0.92 \\
\hline 13 & 3098.5 & 2.495 & 6.241 & 86.629 & 1041.72 & 27452.5 & 1687.35 & 0.94 \\
\hline 14 & 3099.5 & 2.463 & 10.501 & 97.130 & 1031.22 & 31161.8 & 1544.68 & 0.95 \\
\hline 15 & 3100.5 & 2.380 & 40.659 & 137.788 & 990.56 & 31273.2 & 1540.39 & 0.95 \\
\hline 16 & 3101.5 & 2.371 & 47.258 & 185.047 & 943.31 & 30821.6 & 1557.77 & 0.95 \\
\hline 17 & 3102.5 & 2.420 & 21.303 & 206.349 & 922.00 & 34314.9 & 1423.41 & 0.96 \\
\hline 18 & 3103.5 & 2.421 & 20.789 & 227.138 & 901.21 & 38614.2 & 1258.05 & 0.97 \\
\hline 19 & 3104.5 & 2.370 & 48.033 & 275.171 & 853.18 & 39394.3 & 1228.05 & 0.97 \\
\hline 20 & 3105.5 & 2.365 & 51.680 & 326.851 & 801.50 & 40171.4 & 1198.16 & 0.97 \\
\hline 21 & 3106.5 & 2.367 & 49.823 & 376.674 & 751.68 & 42002.8 & 1127.72 & 0.97 \\
\hline 22 & 3107.5 & 2.337 & 81.151 & 457.826 & 670.53 & 38991.1 & 1243.56 & 0.97 \\
\hline ** & $* *$ & $* *$ & ** & $* *$ & $\star *$ & ** & $* *$ & $* *$ \\
\hline 23 & 3108.5 & 2.300 & 148.114 & 605.940 & 522.41 & 25075.8 & 1778.76 & 0.93 \\
\hline 24 & 3109.5 & 2.290 & 176.407 & 782.347 & 346.00 & 9961.96 & 2360.06 & 0.76 \\
\hline 25 & 3110.5 & 2.295 & 161.972 & 944.319 & 184.03 & 1488.26 & 2685.97 & 0.00 \\
\hline 26 & 3111.5 & 2.312 & 122.354 & 1066.673 & 61.68 & 192.70 & 2735.80 & 0.00 \\
\hline 27 & 3112.5 & 2.368 & 49.019 & 1115.692 & 12.66 & 792.18 & 2712.74 & 0.00 \\
\hline 28 & 3113.5 & 2.452 & 12.660 & 1128.352 & 0.00 & -- & -- & -- \\
\hline
\end{tabular}


Table E.4 Flow Unit calculation for Predicted Permeability into three zones for F. R. Ball 19

\begin{tabular}{|c|c|c|c|c|c|c|c|c|}
\hline $\begin{array}{l}\text { Sample No. } \\
\text { per Group }\end{array}$ & $\begin{array}{l}\text { Mid Point } \\
\text { Depth } \\
\mathrm{ft}\end{array}$ & $\begin{array}{c}\text { Average } \\
\text { Log } \\
\text { Density }\end{array}$ & $\begin{array}{l}\text { Predicted } \\
\text { Perm. }\end{array}$ & $\begin{array}{l}\text { Cum. Sum of } \\
\text { Permeability }\end{array}$ & $\begin{array}{l}\text { Grand Sum } \\
\text { Minus } \\
\text { Cum Sum } \\
\text { (mD) }\end{array}$ & $\begin{array}{c}\mathrm{B} \\
\left(\mathrm{mD}^{2}\right)\end{array}$ & $\begin{array}{c}W \\
\left(m D^{2}\right)\end{array}$ & $\begin{array}{l}\text { Zonation } \\
\text { Index, R }\end{array}$ \\
\hline 1 & 3086.5 & 2.648 & 0.521 & 0.521 & 457.31 & 19711.3 & 1276.04 & 0.94 \\
\hline 2 & 3087.5 & 2.601 & 1.113 & 1.634 & 456.19 & 19935.3 & 1258.11 & 0.94 \\
\hline 3 & 3088.5 & 2.573 & 1.748 & 3.382 & 454.44 & 20168.5 & 1239.46 & 0.94 \\
\hline 4 & 3089.5 & 2.566 & 1.959 & 5.341 & 452.48 & 20422.7 & 1219.12 & 0.94 \\
\hline 5 & 3090.5 & 2.549 & 2.583 & 7.924 & 449.90 & 20691.4 & 1197.63 & 0.94 \\
\hline 6 & 3091.5 & 2.515 & 4.526 & 12.451 & 445.38 & 20943.5 & 1177.46 & 0.94 \\
\hline 7 & 3092.5 & 2.489 & 6.908 & 19.359 & 438.47 & 21167.1 & 1159.57 & 0.95 \\
\hline 8 & 3093.5 & 2.455 & 12.057 & 31.417 & 426.41 & 21287.3 & 1149.96 & 0.95 \\
\hline 9 & 3094.5 & 2.430 & 18.032 & 49.449 & 408.38 & 21282.0 & 1150.38 & 0.95 \\
\hline 10 & 3095.5 & 2.425 & 19.480 & 68.929 & 388.90 & 21271.2 & 1151.25 & 0.95 \\
\hline 11 & 3096.5 & 2.491 & 6.687 & 75.616 & 382.21 & 21632.0 & 1122.38 & 0.95 \\
\hline 12 & 3097.5 & 2.512 & 4.772 & 80.388 & 377.44 & 22124.1 & 1083.01 & 0.95 \\
\hline 13 & 3098.5 & 2.495 & 6.241 & 86.629 & 371.20 & 22675.4 & 1038.91 & 0.95 \\
\hline 14 & 3099.5 & 2.463 & 10.501 & 97.130 & 360.70 & 23200.2 & 996.93 & 0.96 \\
\hline 15 & 3100.5 & 2.380 & 40.659 & 137.788 & 320.04 & 22680.7 & 1038.48 & 0.95 \\
\hline 16 & 3101.5 & 2.371 & 47.258 & 185.047 & 272.78 & 22002.6 & 1092.73 & 0.95 \\
\hline 17 & 3102.5 & 2.420 & 21.303 & 206.349 & 251.48 & 22308.3 & 1068.28 & 0.95 \\
\hline 18 & 3103.5 & 2.421 & 20.789 & 227.138 & 230.69 & 22817.1 & 1027.57 & 0.95 \\
\hline 19 & 3104.5 & 2.370 & 48.033 & 275.171 & 182.65 & 22284.9 & 1070.15 & 0.95 \\
\hline 20 & 3105.5 & 2.365 & 51.680 & 326.851 & 130.97 & 21691.3 & 1117.64 & 0.95 \\
\hline 21 & 3106.5 & 2.367 & 49.823 & 376.674 & 81.15 & 21402.9 & 1140.71 & 0.95 \\
\hline 22 & 3107.5 & 2.337 & 81.151 & 457.826 & 0.00 & -- & -- & -- \\
\hline$* *$ & ** & $* *$ & $* *$ & $* *$ & $* *$ & ** & ** & ** \\
\hline 1 & 3108.5 & 2.300 & 148.114 & 148.114 & 603.56 & 29426.3 & 498.84 & 0.98 \\
\hline 2 & 3109.5 & 2.290 & 176.407 & 324.522 & 427.16 & 31164.8 & 359.76 & 0.99 \\
\hline 3 & 3110.5 & 2.295 & 161.972 & 486.493 & 265.18 & 33194.8 & 197.35 & 0.99 \\
\hline 4 & 3111.5 & 2.312 & 122.354 & 608.847 & 142.83 & 33465.4 & 175.71 & 0.99 \\
\hline ** & ** & $\star *$ & $* *$ & $\star *$ & $* *$ & $* *$ & $* *$ & $* *$ \\
\hline 5 & 3112.5 & 2.368 & 49.019 & 657.866 & 93.81 & 29707.5 & 476.34 & 0.98 \\
\hline 6 & 3113.5 & 2.452 & 12.660 & 670.527 & 81.15 & -- & -- & -- \\
\hline
\end{tabular}


Table E.5 Flow Unit calculation for Predicted Permeability into two zones for Lemasters 13

\begin{tabular}{|c|c|c|c|c|c|c|c|c|}
\hline $\begin{array}{l}\text { Sample No. } \\
\text { per Group }\end{array}$ & $\begin{array}{l}\text { Mid Point } \\
\text { Depth } \\
\mathrm{ft}\end{array}$ & $\begin{array}{l}\text { Average } \\
\text { Log } \\
\text { Density }\end{array}$ & $\begin{array}{l}\text { Predicted } \\
\text { Perm. }\end{array}$ & $\begin{array}{l}\text { Cum. Sum of } \\
\text { Permeability }\end{array}$ & $\begin{array}{c}\text { Grand } \\
\text { Sum Minus } \\
\text { Cum Sum } \\
\text { (mD) }\end{array}$ & $\begin{array}{c}B \\
\left(m D^{2}\right)\end{array}$ & $\begin{array}{c}W \\
\left(m^{2}\right)\end{array}$ & $\begin{array}{l}\text { Zonation } \\
\text { Index, R }\end{array}$ \\
\hline 1 & $3,048.50$ & 2.437 & 16.739 & 16.74 & 60.129 & 2.33 & 76.45 & 0.000 \\
\hline 2 & $3,049.50$ & 2.404 & 27.335 & 44.07 & 32.794 & 148.00 & 27.89 & 0.812 \\
\hline ** & ** & $* *$ & ** & ** & ** & $* \star$ & $\star *$ & $* *$ \\
\hline 3 & $3,050.50$ & 2.485 & 8.241 & 52.31 & 24.553 & 31.97 & 66.57 & 0.000 \\
\hline 4 & $3,051.50$ & 2.476 & 9.390 & 61.70 & 15.163 & 0.06 & 77.21 & 0.000 \\
\hline 5 & $3,052.50$ & 2.444 & 15.164 & 76.87 & 0.000 & -- & -- & -- \\
\hline
\end{tabular}

Table E.6 Flow Unit calculation for Predicted Permeability into two zones for T. Heirs 8

\begin{tabular}{ccccccccc}
\multicolumn{2}{c}{$\begin{array}{c}\text { Sample No. Mid Point } \\
\text { per Group } \\
\text { Depth } \\
\mathrm{ft}\end{array}$} & $\begin{array}{c}\text { Average } \\
\text { Log } \\
\text { Density }\end{array}$ & $\begin{array}{c}\text { Predicted } \\
\text { Perm. }\end{array}$ & $\begin{array}{c}\text { Cum. Sum of } \\
\text { Permeability }\end{array}$ & $\begin{array}{c}\text { Grand } \\
\text { Sum Minus } \\
\text { Cum Sum } \\
(\mathrm{mD})\end{array}$ & $\begin{array}{c}\mathrm{B} \\
\left(\mathrm{mD}^{2}\right)\end{array}$ & $\begin{array}{c}\mathrm{W} \\
\left(\mathrm{mD}^{2}\right)\end{array}$ & $\begin{array}{c}\text { Zonation } \\
\text { Index, } \mathrm{R}\end{array}$ \\
1 & 2790.5 & 2.468 & 11.176 & 11.176 & 198.783 & 413.13 & 482.50 & 0.00 \\
2 & 2791.5 & 2.472 & 10.437 & 21.613 & 188.346 & 1030.8 & 358.96 & 0.65 \\
3 & 2792.5 & 2.468 & 11.049 & 32.662 & 177.297 & 1916.6 & 181.81 & 0.91 \\
4 & 2793.5 & 2.420 & 23.111 & 55.773 & 154.186 & 2404.6 & 84.22 & 0.96 \\
$* *$ & $* *$ & $* *$ & $* *$ & $* *$ & $* *$ & $*$ & $*$ & $*$ \\
5 & 2794.5 & 2.387 & 38.182 & 93.955 & 116.004 & 2196.4 & 125.85 & 0.94 \\
6 & 2795.5 & 2.365 & 53.159 & 147.115 & 62.844 & 1258.9 & 313.33 & 0.75 \\
7 & 2796.5 & 2.354 & 62.844 & 209.959 & 0.000 & -- & -- & --
\end{tabular}


Table E.7 Flow Unit calculation for Predicted Permeability into two zones for P. Horner 9

$\begin{array}{ccccccccc}\begin{array}{c}\text { Sample No. Mid Point } \\ \text { per Group } \\ \text { Depth } \\ \mathrm{ft}\end{array} & \begin{array}{c}\text { Average } \\ \text { Log } \\ \text { Density }\end{array} & \begin{array}{c}\text { Predicted } \\ \text { Perm. }\end{array} & \begin{array}{c}\text { Cum. Sum of } \\ \text { Permeability }\end{array} & \begin{array}{c}\text { Grand } \\ \text { Sum Minus } \\ \text { Cum Sum } \\ (\mathrm{mD})\end{array} & \begin{array}{c}\mathrm{B} \\ \left(\mathrm{mD}^{2}\right)\end{array} & \begin{array}{c}\mathrm{W} \\ \left(\mathrm{mD}^{2}\right)\end{array} & \begin{array}{c}\text { Zonation } \\ \text { Index, R }\end{array} \\ 1 & 2891.5 & 2.576 & 1.45 & 1.45 & 1099.29 & 5544.21 & 3550.88 & 0.36 \\ 2 & 2892.5 & 2.503 & 4.62 & 6.07 & 1094.66 & 11419.84 & 3098.90 & 0.73 \\ 3 & 2893.5 & 2.463 & 8.79 & 14.86 & 1085.87 & 17558.62 & 2626.69 & 0.85 \\ 4 & 2894.5 & 2.434 & 13.86 & 28.72 & 1072.01 & 23905.13 & 2138.50 & 0.91 \\ 5 & 2895.5 & 2.401 & 23.57 & 52.29 & 1048.44 & 29696.02 & 1693.04 & 0.94 \\ 6 & 2896.5 & 2.358 & 46.82 & 99.11 & 1001.62 & 32335.20 & 1490.03 & 0.95 \\ 7 & 2897.5 & 2.341 & 61.17 & 160.28 & 940.45 & 33451.71 & 1404.15 & 0.96 \\ 8 & 2898.5 & 2.339 & 63.66 & 223.95 & 876.79 & 35316.6 & 1260.69 & 0.96 \\ * * & * * * & * * & * * & * * & * * & * * & * & * * \\ 9 & 2899.5 & 2.311 & 98.76 & 322.71 & 778.03 & 31684.4 & 1540.09 & 0.95 \\ 10 & 2900.5 & 2.287 & 146.03 & 468.74 & 631.99 & 21080.7 & 2355.76 & 0.89 \\ 11 & 2901.5 & 2.277 & 169.27 & 638.01 & 462.72 & 9759.0 & 3226.66 & 0.67 \\ 12 & 2902.5 & 2.277 & 171.31 & 809.32 & 291.41 & 2116.1 & 3814.58 & 0.00 \\ 13 & 2903.5 & 2.287 & 144.87 & 954.19 & 146.54 & 0.03 & 3977.35 & 0.00 \\ 14 & 2904.5 & 2.314 & 93.76 & 1047.96 & 52.77 & 455.00 & 3942.35 & 0.00 \\ 15 & 2905.5 & 2.350 & 52.78 & 1100.73 & 0.00 & -- & -- & --\end{array}$

Table E.8 Flow Unit calculation for Predicted Permeability into three zones for P. Horner 9

\begin{tabular}{ccccccccc}
\multicolumn{2}{c}{$\begin{array}{c}\text { Sample No. Mid Point } \\
\text { per Group } \\
\text { Depth } \\
\mathrm{ft}\end{array}$} & $\begin{array}{c}\text { Average } \\
\text { Log } \\
\text { Density }\end{array}$ & $\begin{array}{c}\text { Predicted } \\
\text { Perm. }\end{array}$ & $\begin{array}{c}\text { Cum. Sum of } \\
\text { Permeability }\end{array}$ & $\begin{array}{c}\text { Grand } \\
\text { Sum Minus } \\
\text { Cum Sum } \\
(\mathrm{mD})\end{array}$ & $\begin{array}{c}\mathrm{B} \\
\left(\mathrm{mD}^{2}\right)\end{array}$ & $\begin{array}{c}\text { W } \\
\left(\mathrm{mD}^{2}\right)\end{array}$ & $\begin{array}{c}\text { Zonation } \\
\text { Index, R }\end{array}$ \\
1 & 2891.5 & 2.576 & 1.45 & 1.45 & 222.50 & 18061.10 & 1298.62 & 0.93 \\
2 & 2892.5 & 2.503 & 4.62 & 6.07 & 217.88 & 18488.93 & 1227.31 & 0.93 \\
3 & 2893.5 & 2.463 & 8.79 & 14.86 & 209.08 & 18932.29 & 1153.42 & 0.94 \\
4 & 2894.5 & 2.434 & 13.86 & 28.72 & 195.22 & 19391.07 & 1076.96 & 0.94 \\
5 & 2895.5 & 2.401 & 23.57 & 52.29 & 171.66 & 19708.40 & 1024.07 & 0.95 \\
6 & 2896.5 & 2.358 & 46.82 & 99.11 & 124.84 & 19238.62 & 1102.36 & 0.94 \\
7 & 2897.5 & 2.341 & 61.17 & 160.28 & 63.67 & 18385.55 & 1244.54 & 0.93 \\
8 & 2898.5 & 2.339 & 63.66 & 223.95 & 0.00 & -- & -- & - \\
$* *$ & $* *$ & $* *$ & $* *$ & $* *$ & $* *$ & $* *$ & $*$ & $* *$ \\
1 & 2899.5 & 2.311 & 98.76 & 98.76 & 778.03 & 18067.96 & 1297.47 & 0.93 \\
2 & 2900.5 & 2.287 & 146.03 & 244.79 & 631.99 & 17669.87 & 1363.82 & 0.92 \\
3 & 2901.5 & 2.277 & 169.27 & 414.06 & 462.72 & 18086.21 & 1294.43 & 0.93 \\
4 & 2902.5 & 2.277 & 171.31 & 585.37 & 291.41 & 19733.79 & 1019.84 & 0.95 \\
5 & 2903.5 & 2.287 & 144.87 & 730.25 & 146.54 & 21441.83 & 735.16 & 0.97 \\
$* *$ & $* *$ & $* *$ & $* *$ & $* *$ & $* *$ & $* *$ & $* *$ & $*$ \\
6 & 2904.5 & 2.314 & 93.76 & 824.01 & 52.78 & 20722.85 & 854.99 & 0.96 \\
7 & 2905.5 & 2.350 & 52.78 & 876.79 & 0.00 & -- & -- & --
\end{tabular}


Table E.9 Flow Unit calculation for Predicted Permeability into two zones for P. Horner 11

\begin{tabular}{ccccccccc}
\multicolumn{2}{c}{$\begin{array}{c}\text { Sample No. Mid Point } \\
\text { per Group } \\
\text { Depth } \\
\mathrm{ft}\end{array}$} & $\begin{array}{c}\text { Average } \\
\text { Log } \\
\text { Density }\end{array}$ & $\begin{array}{c}\text { Predicted } \\
\text { Perm. }\end{array}$ & $\begin{array}{c}\text { Cum. Sum of } \\
\text { Permeability }\end{array}$ & $\begin{array}{c}\text { Grand } \\
\text { Sum Minus } \\
\text { Cum Sum } \\
(\mathrm{mD})\end{array}$ & $\begin{array}{c}\mathrm{B} \\
\left(\mathrm{mD}^{2}\right)\end{array}$ & $\begin{array}{c}\mathrm{W} \\
\left(\mathrm{mD}^{2}\right)\end{array}$ & $\begin{array}{c}\text { Zonation } \\
\text { Index, } \mathrm{R}\end{array}$ \\
1 & 3084.5 & 2.497 & 6.73 & 6.73 & 397.73 & 1263.20 & 2020.35 & 0.00 \\
2 & 3085.5 & 2.487 & 7.85 & 14.57 & 389.89 & 2748.79 & 1834.66 & 0.33 \\
3 & 3086.5 & 2.519 & 4.87 & 19.45 & 385.01 & 4943.54 & 1560.31 & 0.68 \\
4 & 3087.5 & 2.550 & 3.03 & 22.48 & 381.98 & 8086.01 & 1167.50 & 0.86 \\
5 & 3088.5 & 2.455 & 12.68 & 35.15 & 369.31 & 11165.93 & 782.51 & 0.93 \\
$* *$ & $* *$ & $* *$ & $* *$ & $* *$ & $* *$ & $* *$ & $* *$ & $*$ \\
6 & 3089.5 & 2.318 & 98.09 & 133.24 & 271.22 & 4989.94 & 1554.51 & 0.69 \\
7 & 3090.5 & 2.329 & 83.49 & 216.73 & 187.73 & 2098.87 & 1915.90 & 0.09 \\
8 & 3091.5 & 2.315 & 103.76 & 320.50 & 83.97 & 5.91 & 2177.52 & 0.00 \\
9 & 3092.5 & 2.334 & 78.04 & 398.54 & 5.92 & 1324.27 & 2012.72 & 0.00 \\
10 & 3093.5 & 2.506 & 5.92 & 404.46 & 0.00 & -- & -- & --
\end{tabular}

Table E.10 Flow Unit calculation for Predicted Permeability into three zones for P. Horner 11

\begin{tabular}{|c|c|c|c|c|c|c|c|c|}
\hline $\begin{array}{l}\text { Sample No. } \\
\text { per Group }\end{array}$ & $\begin{array}{l}\text { Mid } \\
\text { Point } \\
\text { Depth } \\
\mathrm{ft}\end{array}$ & $\begin{array}{l}\text { Log } \\
\text { Density }\end{array}$ & $\begin{array}{l}\text { Predicted } \\
\text { Perm. }\end{array}$ & $\begin{array}{l}\text { Cum. Sum of } \\
\text { Permeability }\end{array}$ & $\begin{array}{c}\text { Grand } \\
\text { Sum Minus } \\
\text { Cum Sum } \\
\text { (mD) }\end{array}$ & $\begin{array}{c}B \\
\left(m D^{2}\right)\end{array}$ & $\begin{array}{c}W \\
\left(m D^{2}\right)\end{array}$ & $\begin{array}{l}\text { Zonation } \\
\text { Index, R }\end{array}$ \\
\hline 1 & 3084.5 & 2.497 & 6.729 & 6.729 & 28.425 & 5583.04 & 894.28 & 0.84 \\
\hline 2 & 3085.5 & 2.487 & 7.846 & 14.575 & 20.579 & 5583.09 & 894.27 & 0.84 \\
\hline 3 & 3086.5 & 2.519 & 4.875 & 19.450 & 15.704 & 5584.10 & 893.98 & 0.84 \\
\hline 4 & 3087.5 & 2.550 & 3.029 & 22.478 & 12.676 & 5602.89 & 888.61 & 0.84 \\
\hline 5 & 3088.5 & 2.455 & 12.676 & 35.154 & 0.000 & -- & -- & -- \\
\hline ** & $* *$ & $* *$ & $* *$ & $* *$ & $* *$ & $* *$ & ** & $* *$ \\
\hline 1 & 3089.5 & 2.318 & 98.089 & 98.089 & 271.220 & 5949.84 & 789.48 & 0.87 \\
\hline 2 & 3090.5 & 2.329 & 83.491 & 181.580 & 187.729 & 6060.58 & 757.84 & 0.87 \\
\hline 3 & 3091.5 & 2.315 & 103.761 & 285.341 & 83.968 & 7276.65 & 410.39 & 0.94 \\
\hline 4 & 3092.5 & 2.334 & 78.044 & 363.386 & 5.923 & 8467.75 & 70.08 & 0.99 \\
\hline ** & $* *$ & $* *$ & $* *$ & $* *$ & $* *$ & $* *$ & $* *$ & $* *$ \\
\hline 5 & 3093.5 & 2.506 & 5.924 & 369.309 & 0.000 & -- & -- & -- \\
\hline
\end{tabular}




\section{APPENDIX F.}

Flow Unit in the cored wells based on original core permeability data 


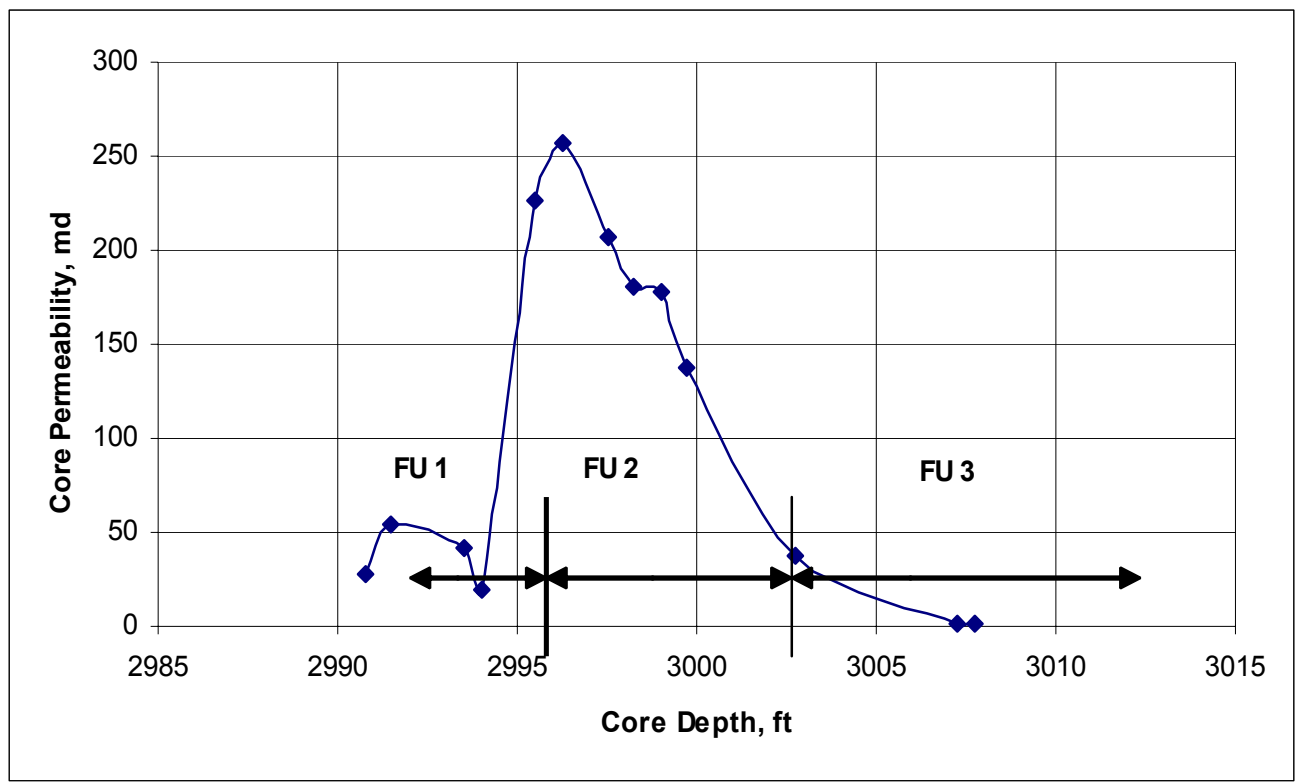

Figure F. 1 Flow Unit identification in F. R. Ball 18

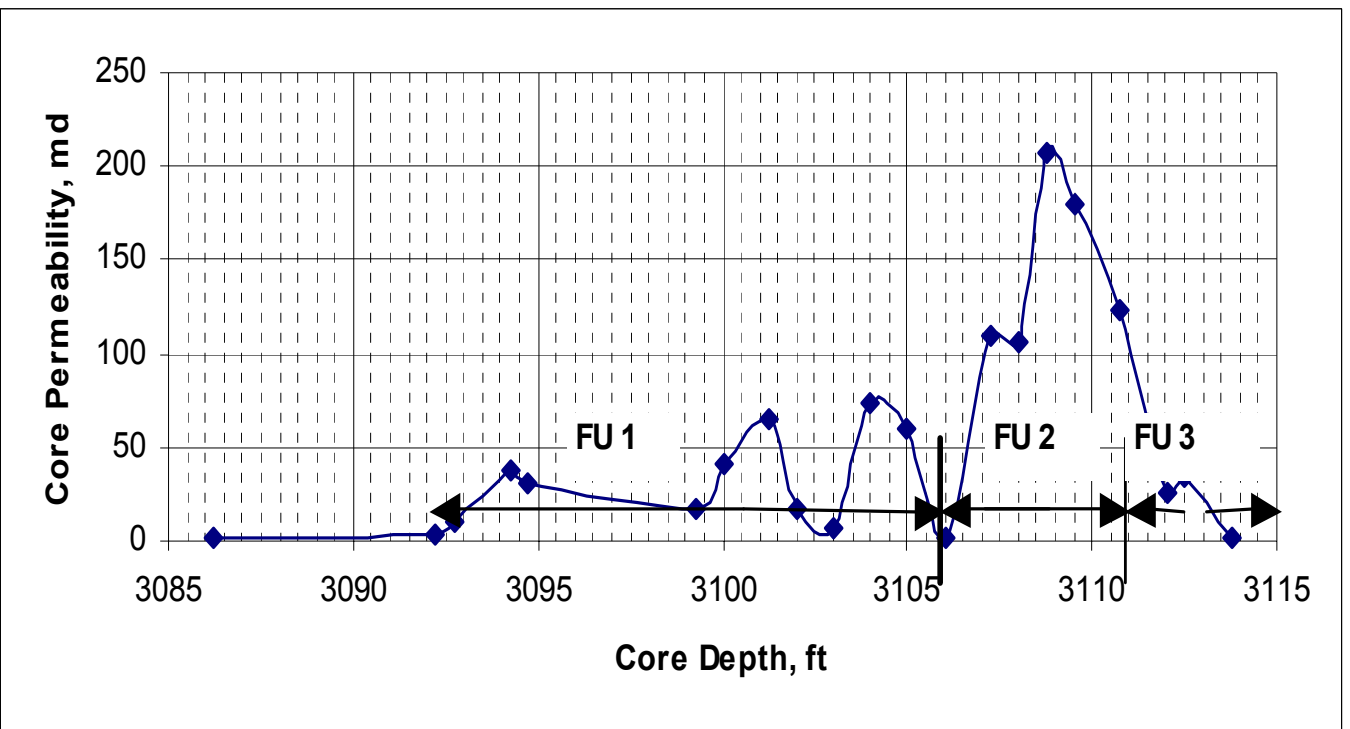

Figure F. 2 Flow Unit identification in F. R. Ball 19 


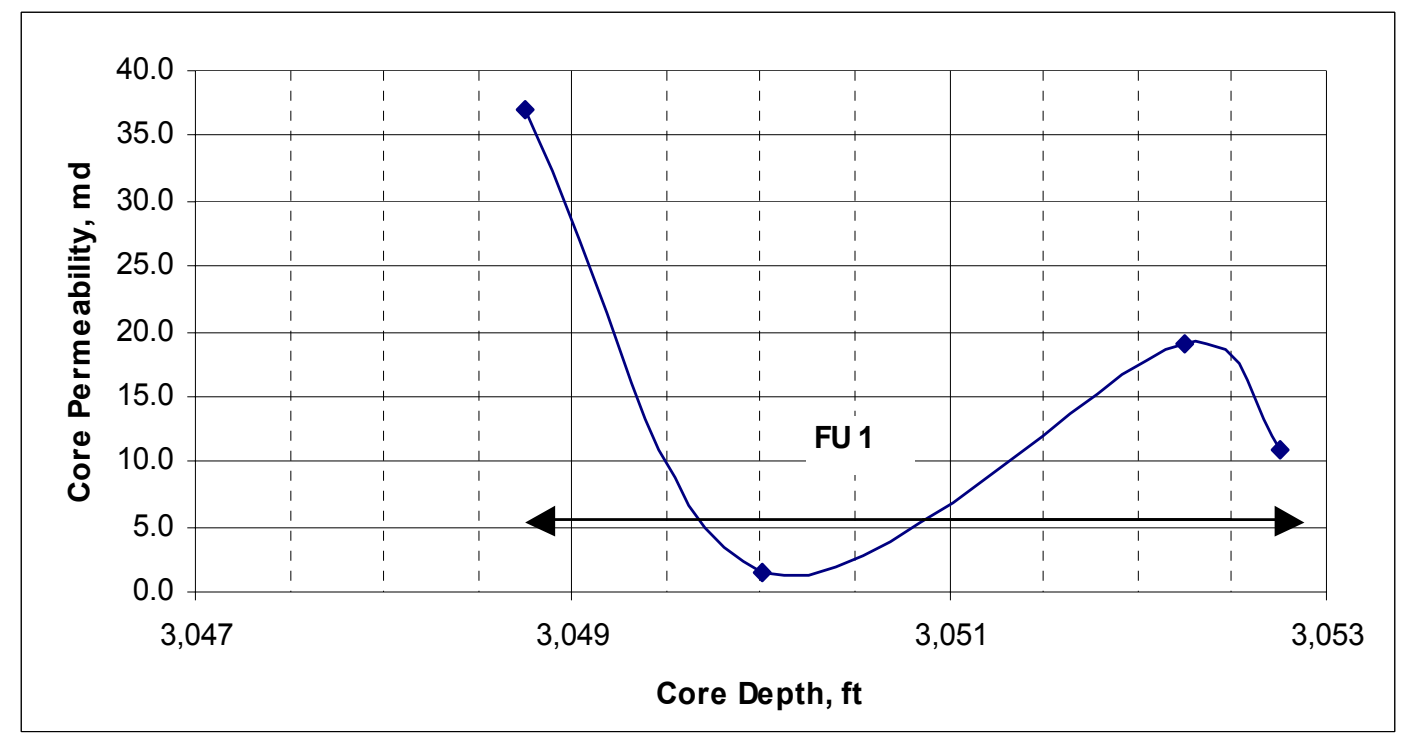

Figure F. 3 Flow Unit identification in Lemasters 13

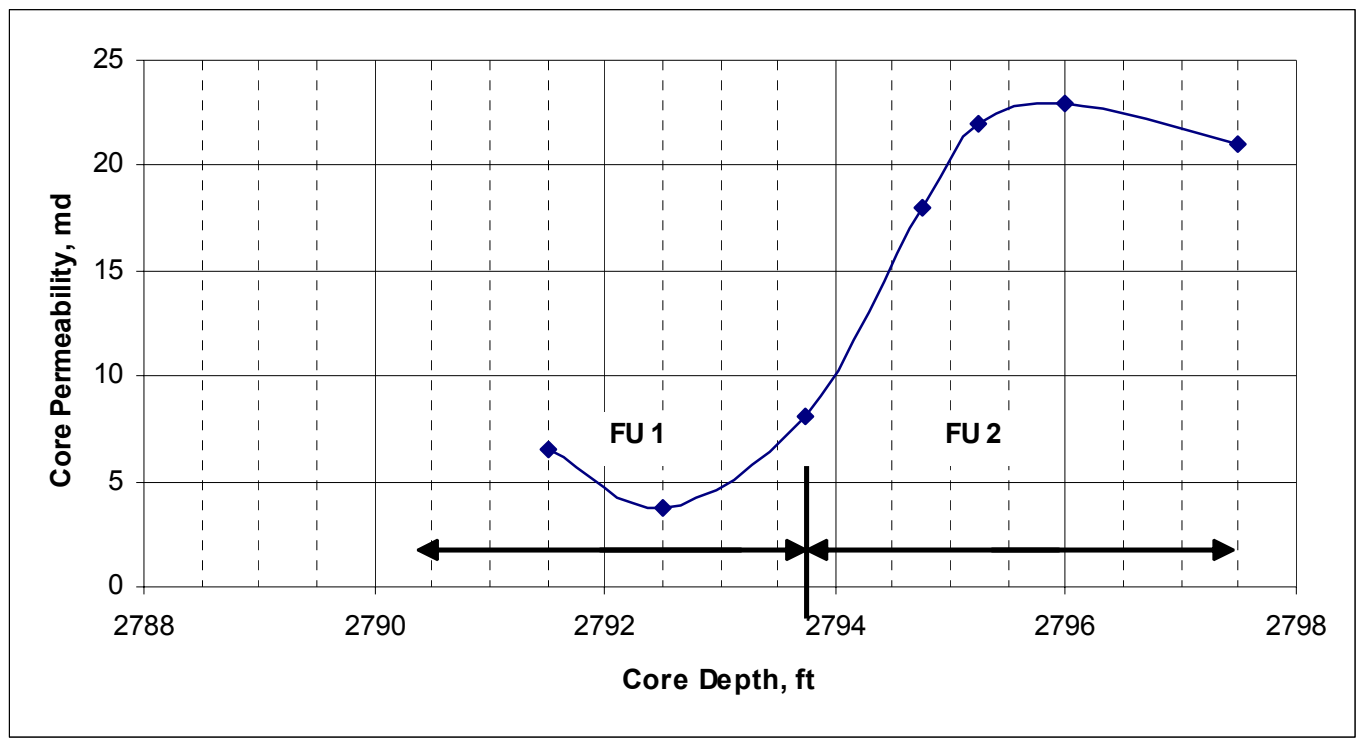

Figure F. 4 Flow Unit identification in T. Heirs 8 


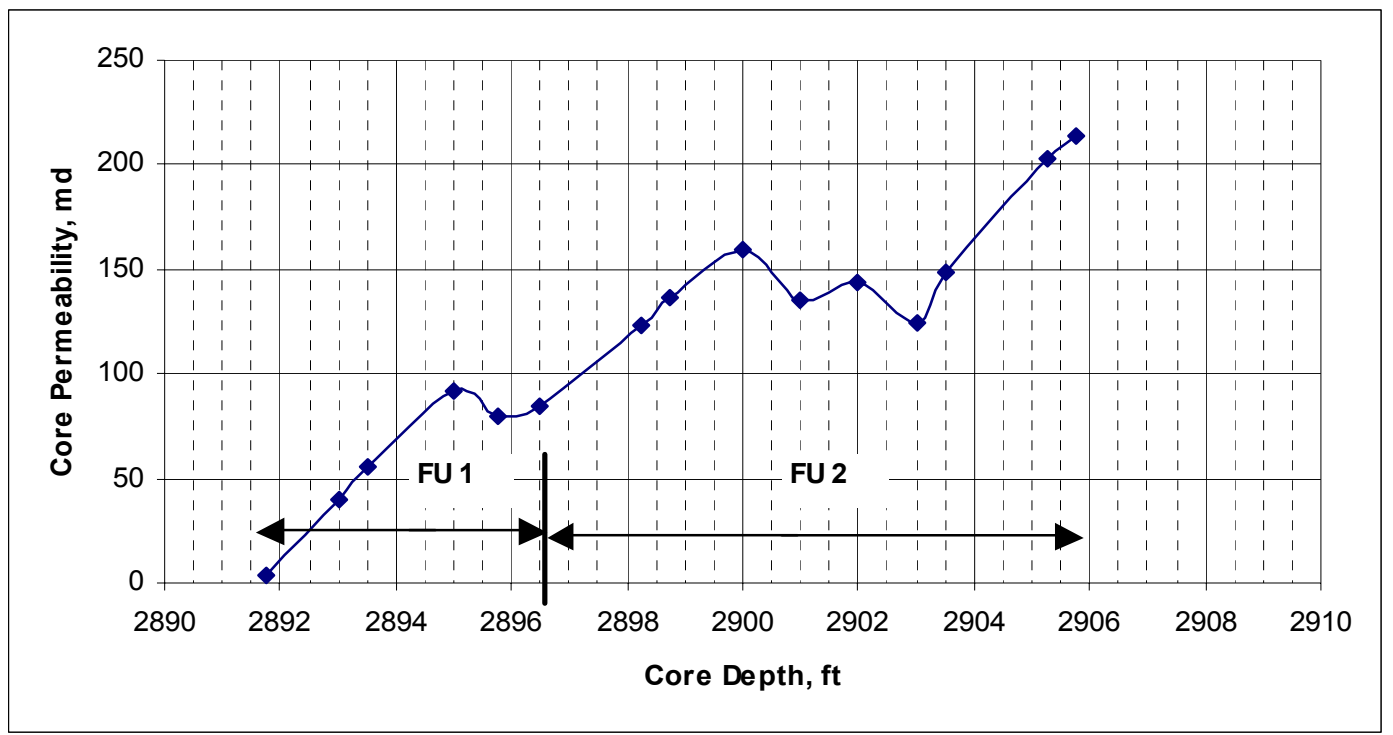

Figure F. 5 Flow Unit identification in P. Horner 9

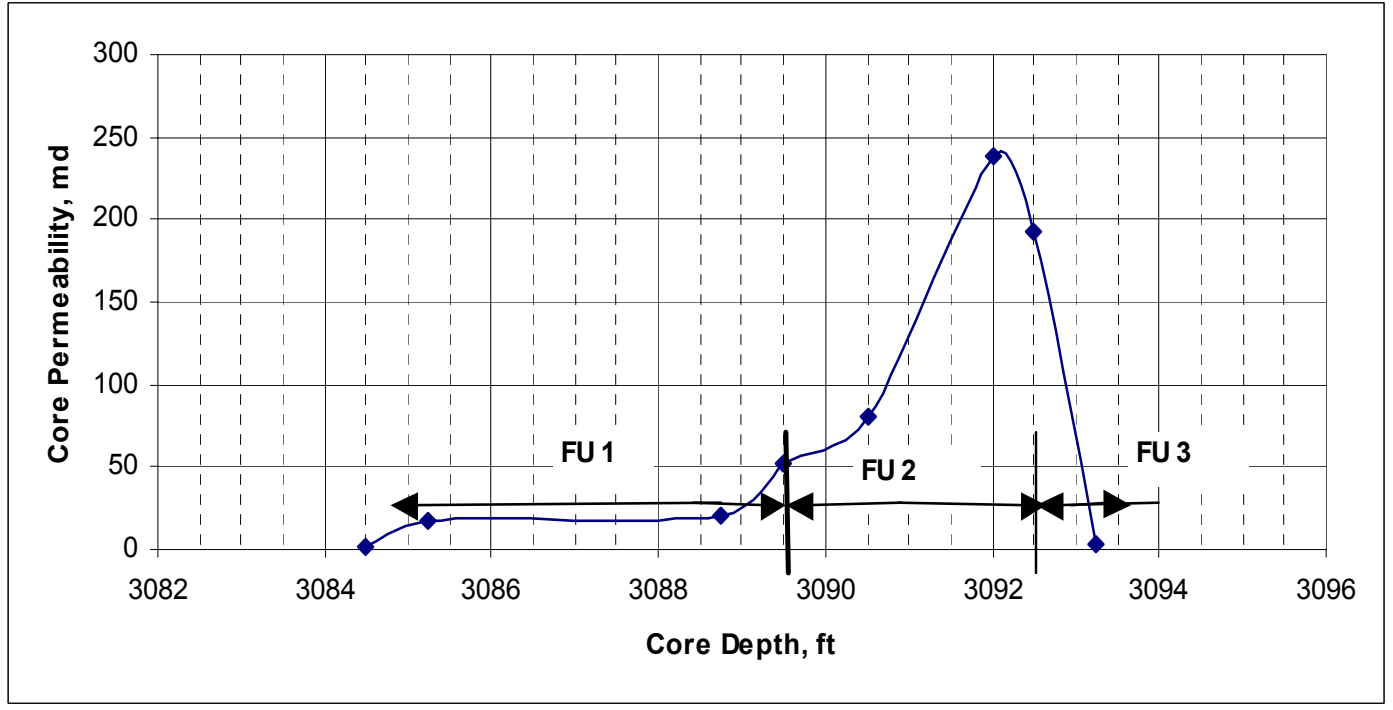

Figure F. 6 Flow Unit identification in P. Horner 11 
APPENDIX G.

Flow Unit identification with Predicted Permeability 


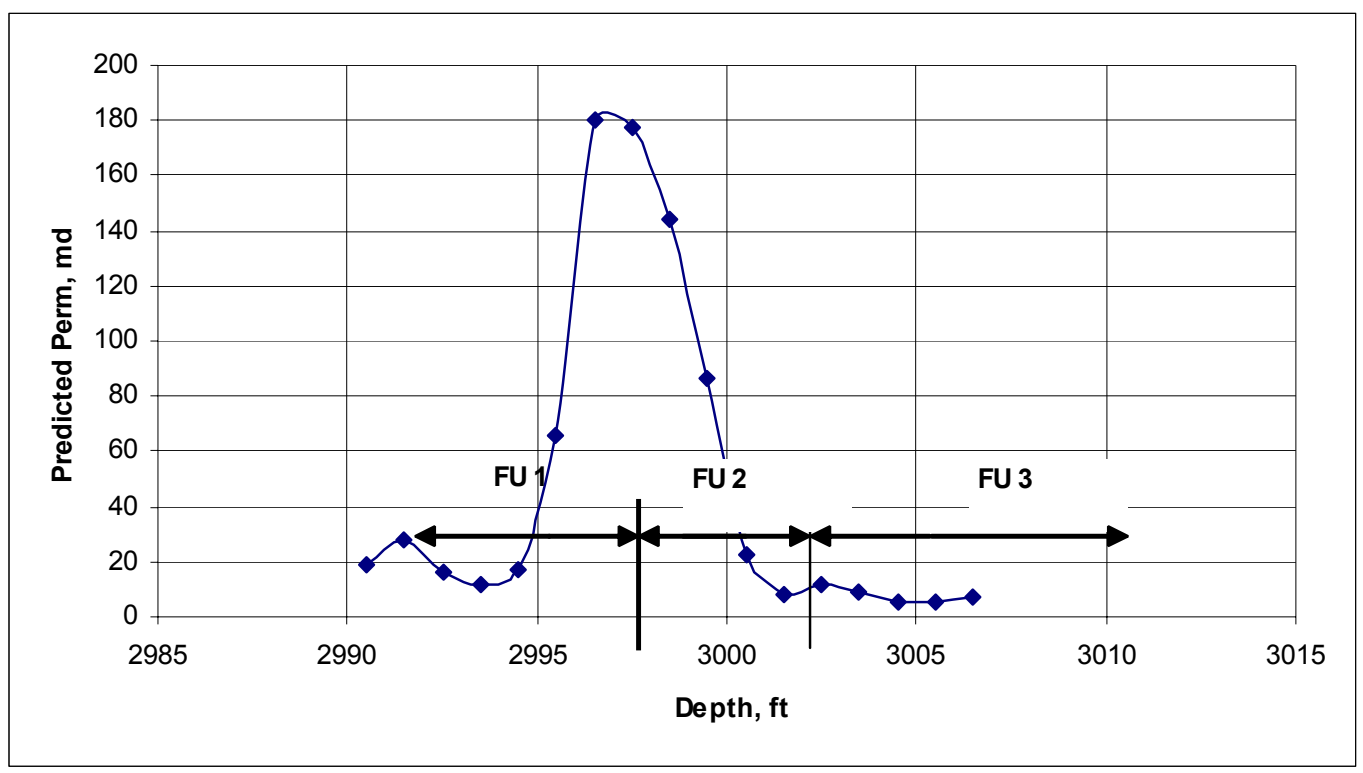

Figure G. 1 Flow Unit identification with Predicted Permeability for F. R. Ball 18

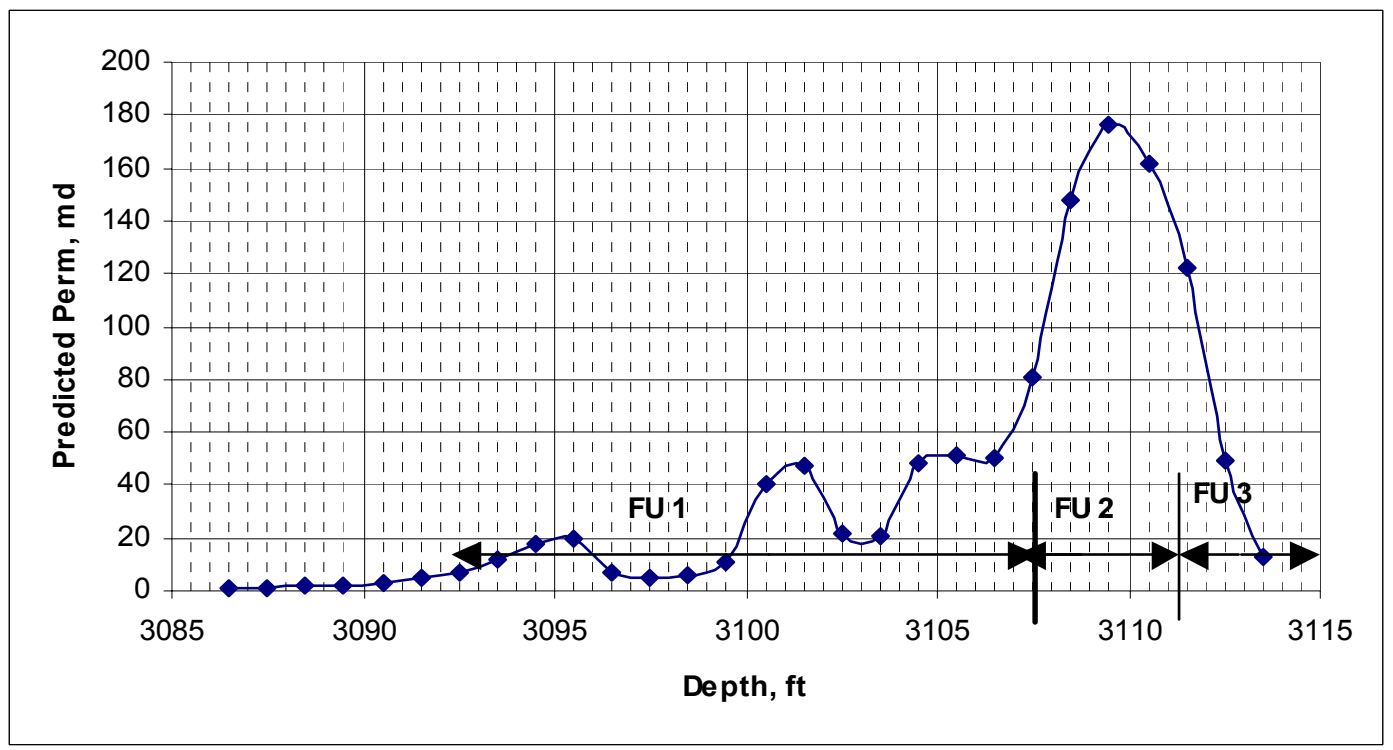

Figure G. 2 Flow Unit identification with Predicted Permeability for F. R. Ball 19 


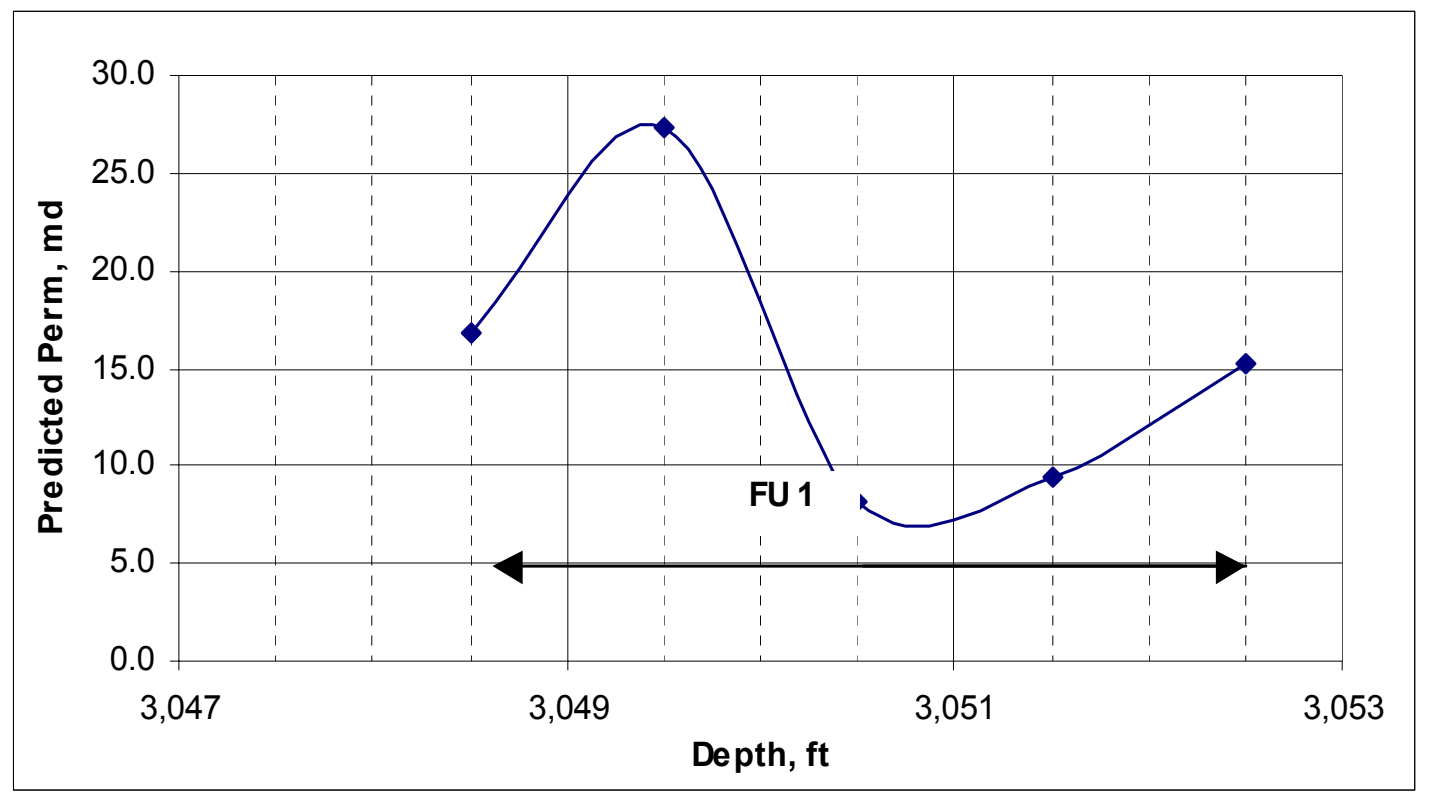

Figure G. 3 Flow Unit identification with Predicted Permeability for Lemasters 13

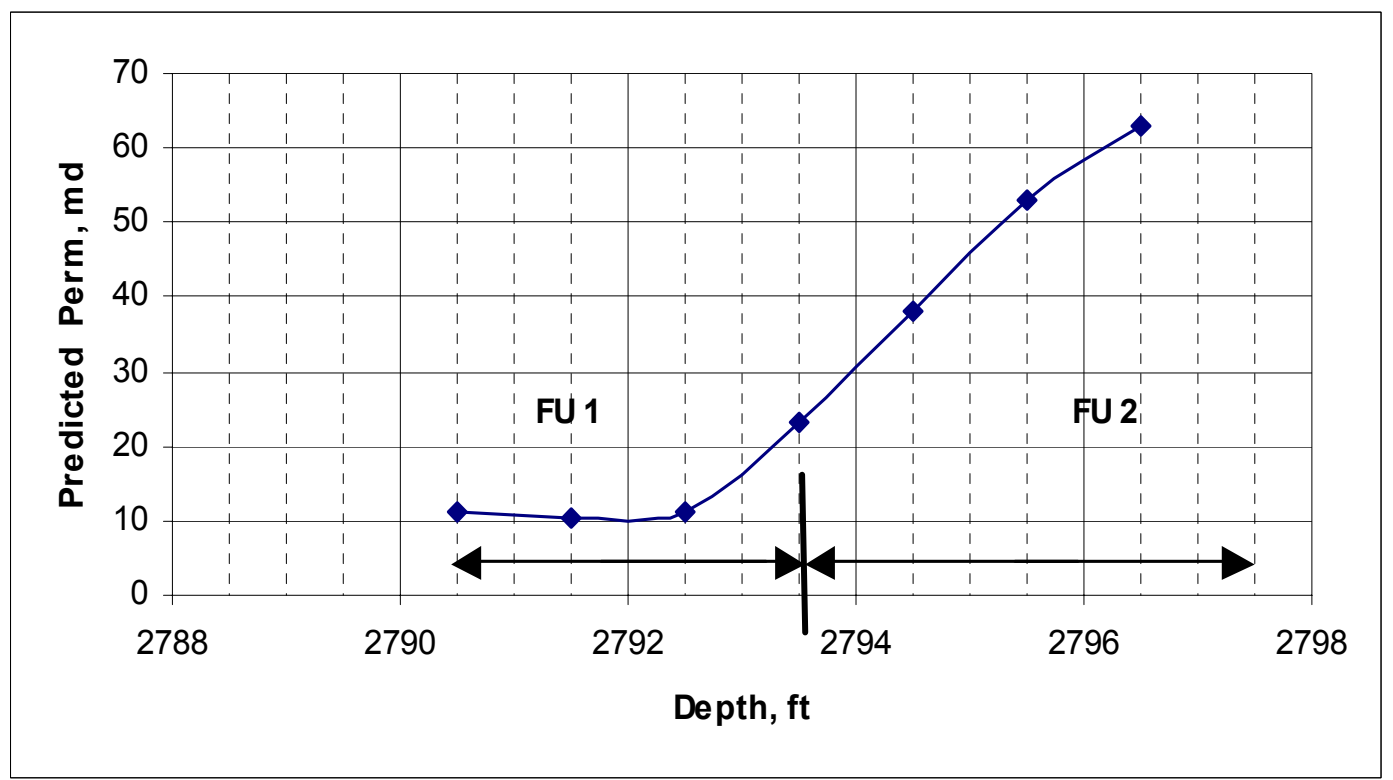

Figure G.4 Flow Unit identification with Predicted Permeability for T. Heirs8 


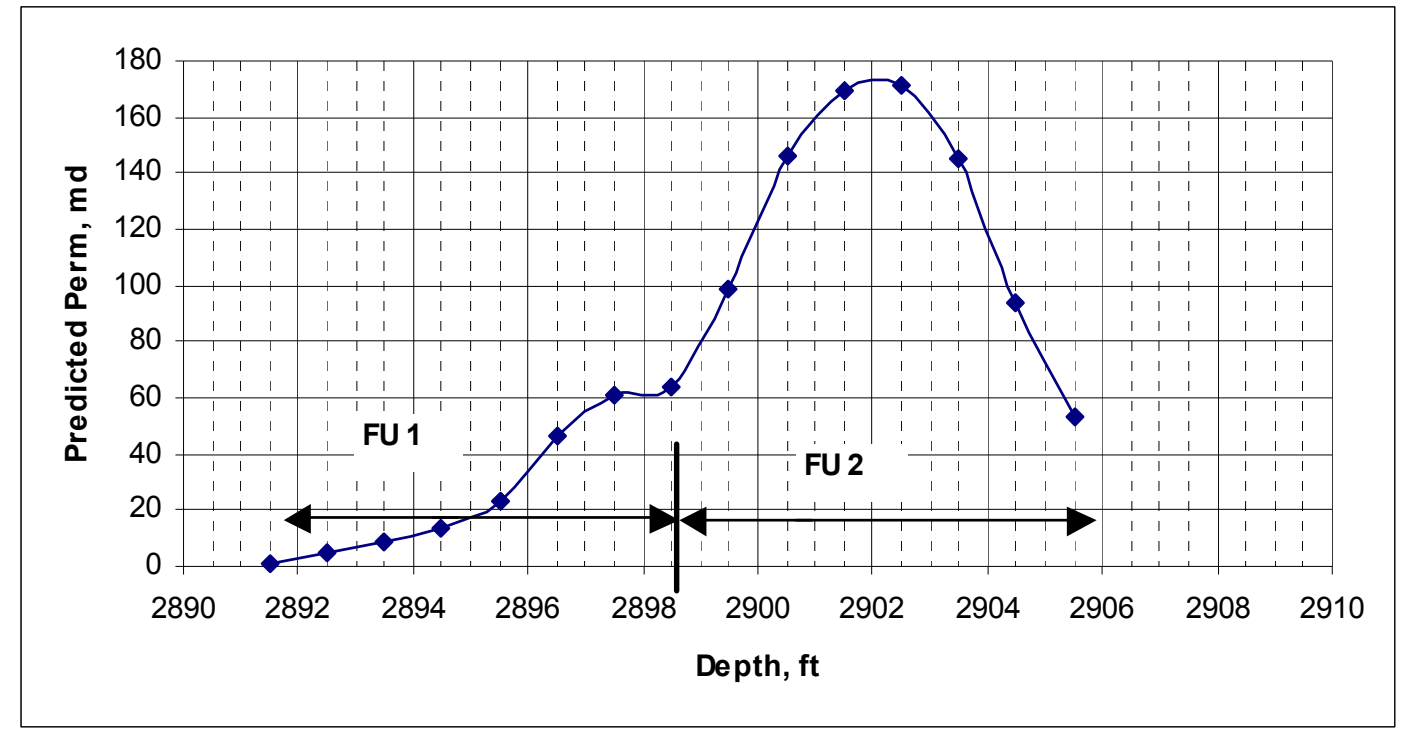

Figure G.5 Flow Unit identification with Predicted Permeability for P. Horner 9

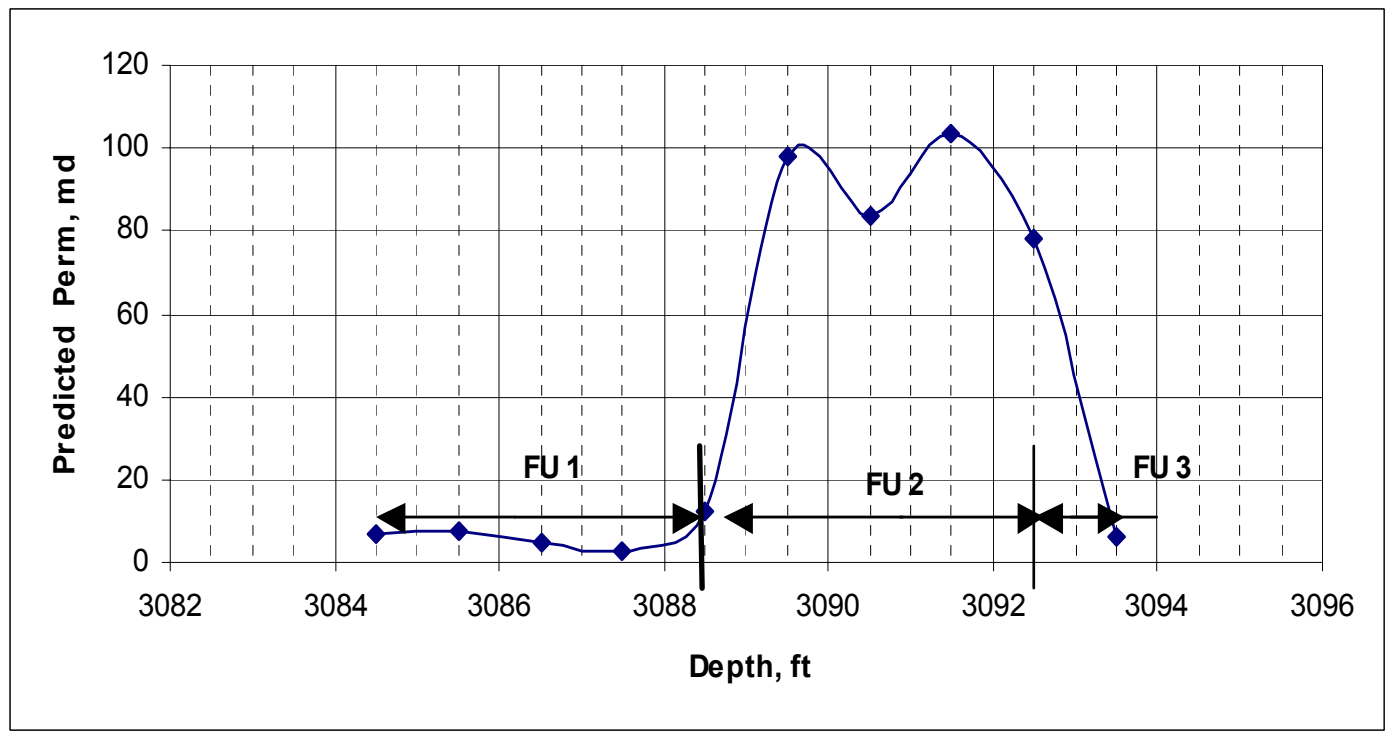

Figure G.6 Flow Unit identification with Predicted Permeability for $P$. Horner 11 


\section{APPENDIX H}

Figure of flow unit correlation 


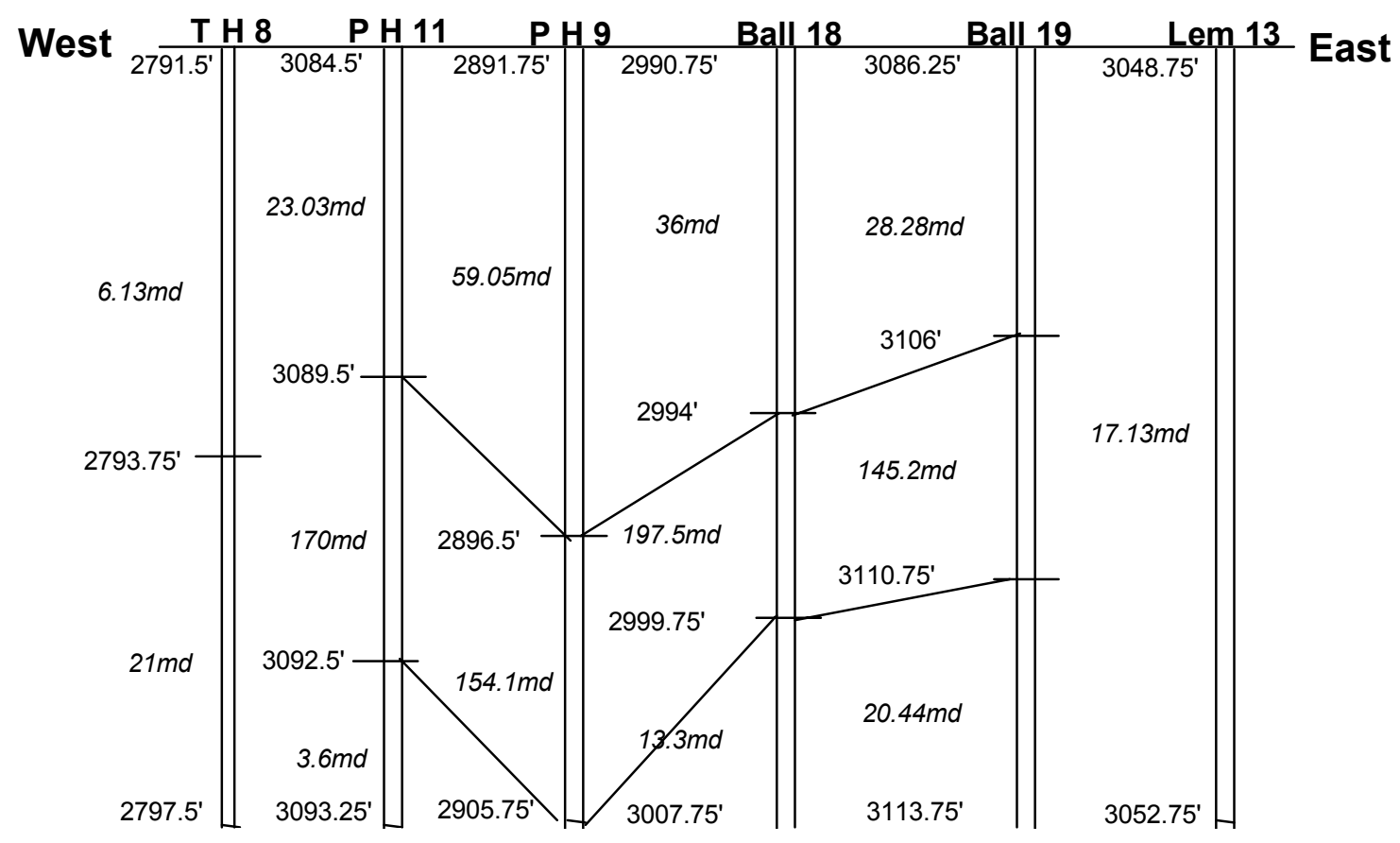

Figure H. 1 : Correlation of flow units from six cored wells.

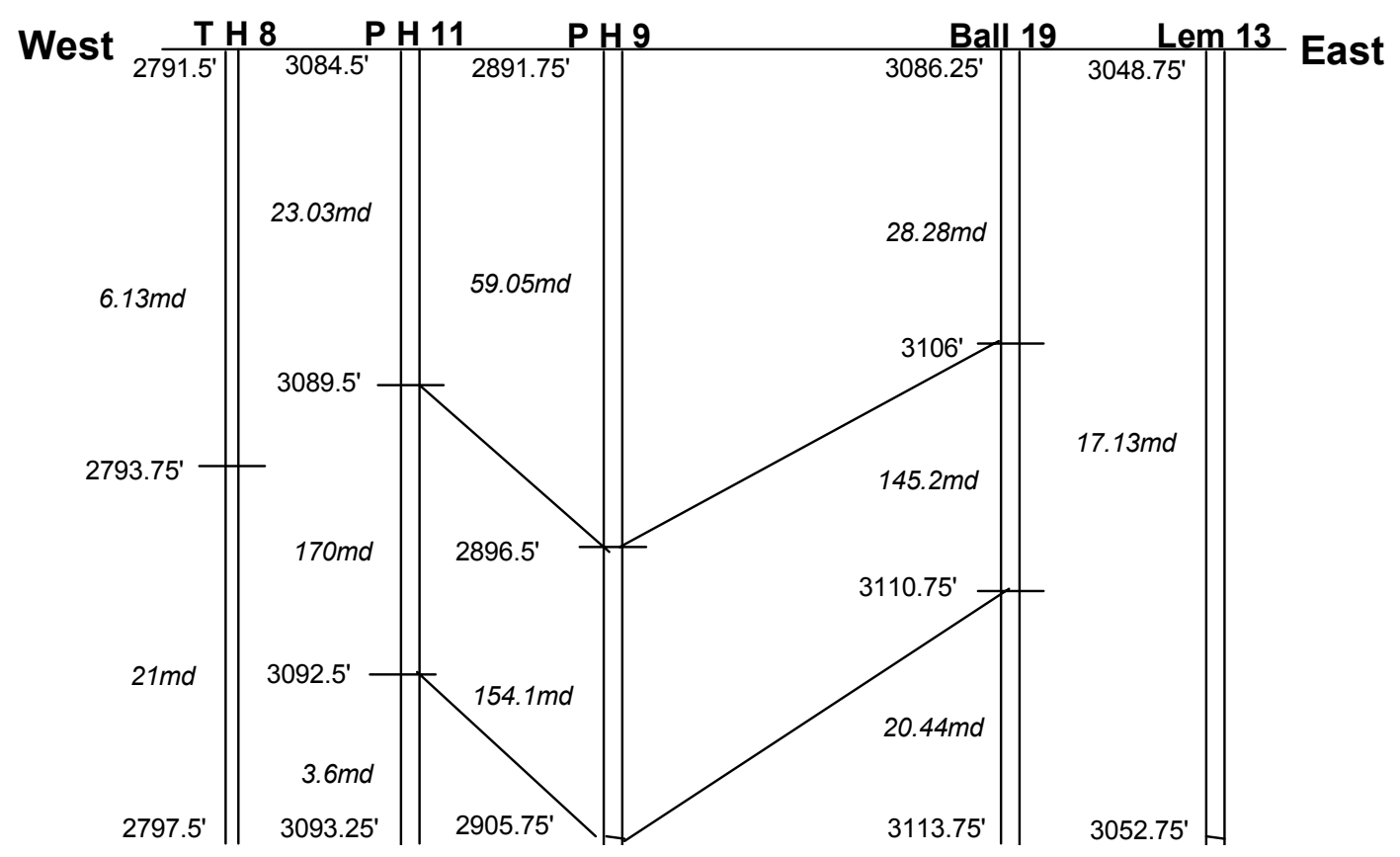

Figure H. 2 : Correlation of flow units from five cored wells (except Ball 18). 


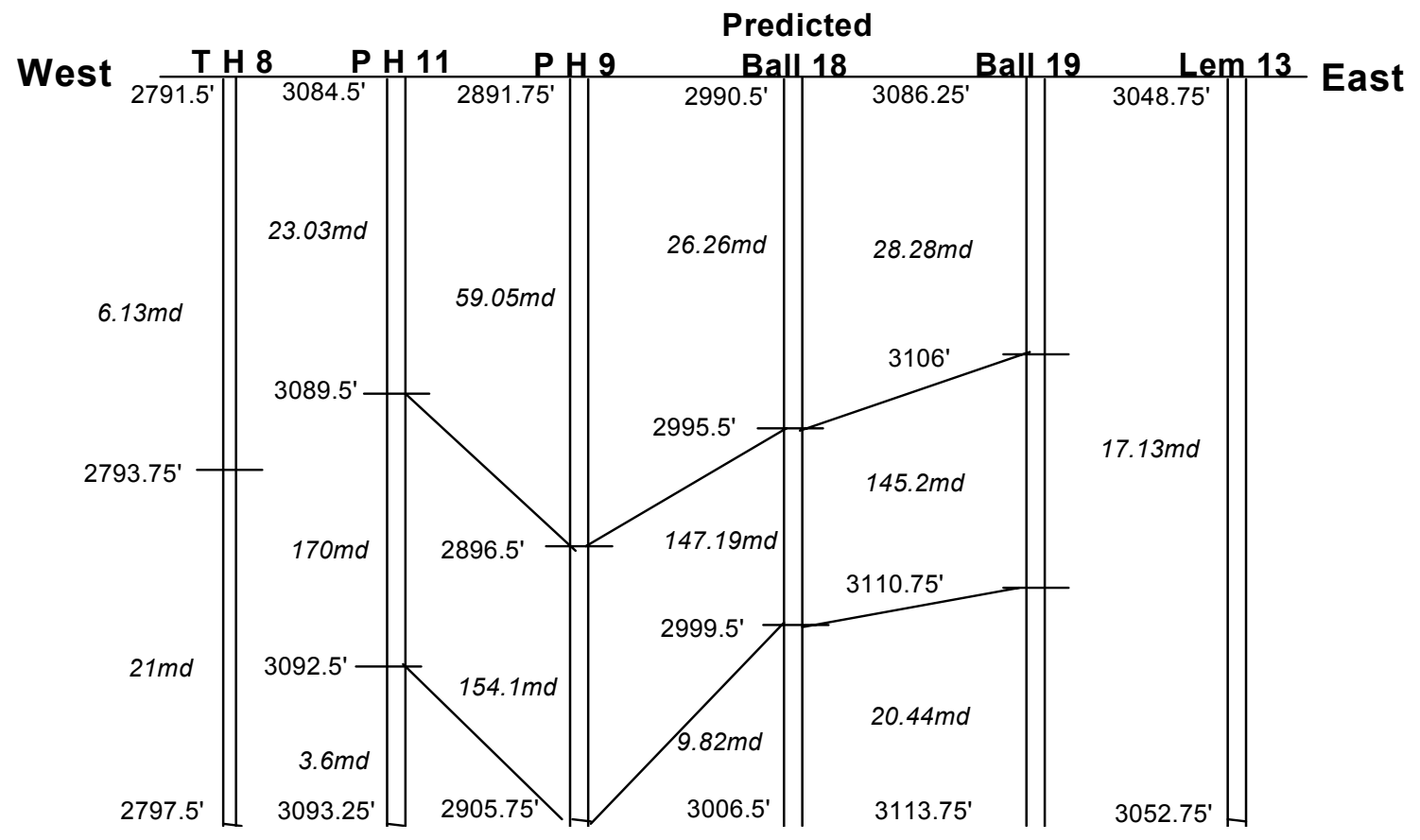

Figure H. 3: Correlation of flow units between predicted Ball 18 and original five cored wells.

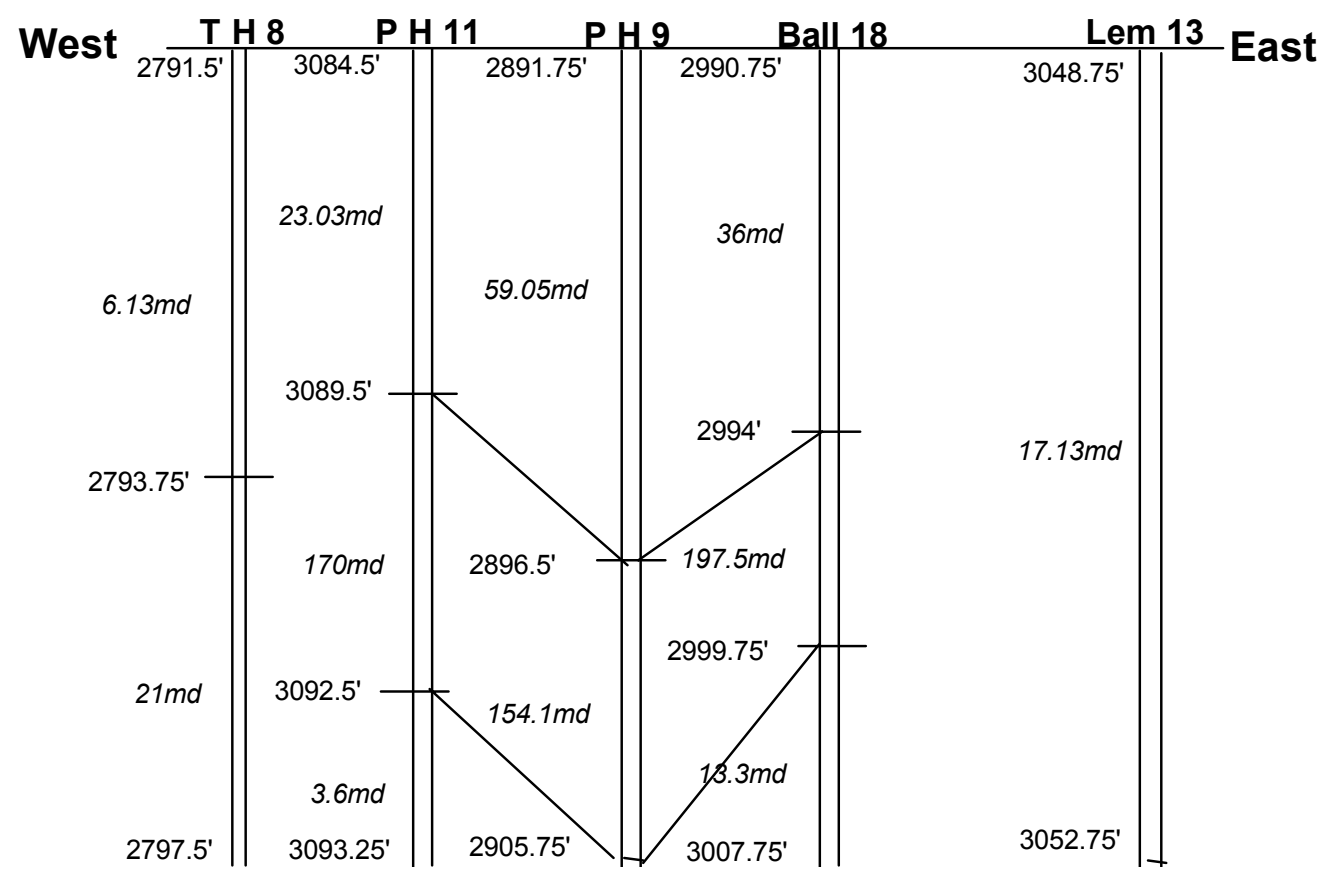

Figure H. 4 : Correlation of flow units from five cored wells (except Ball 19). 


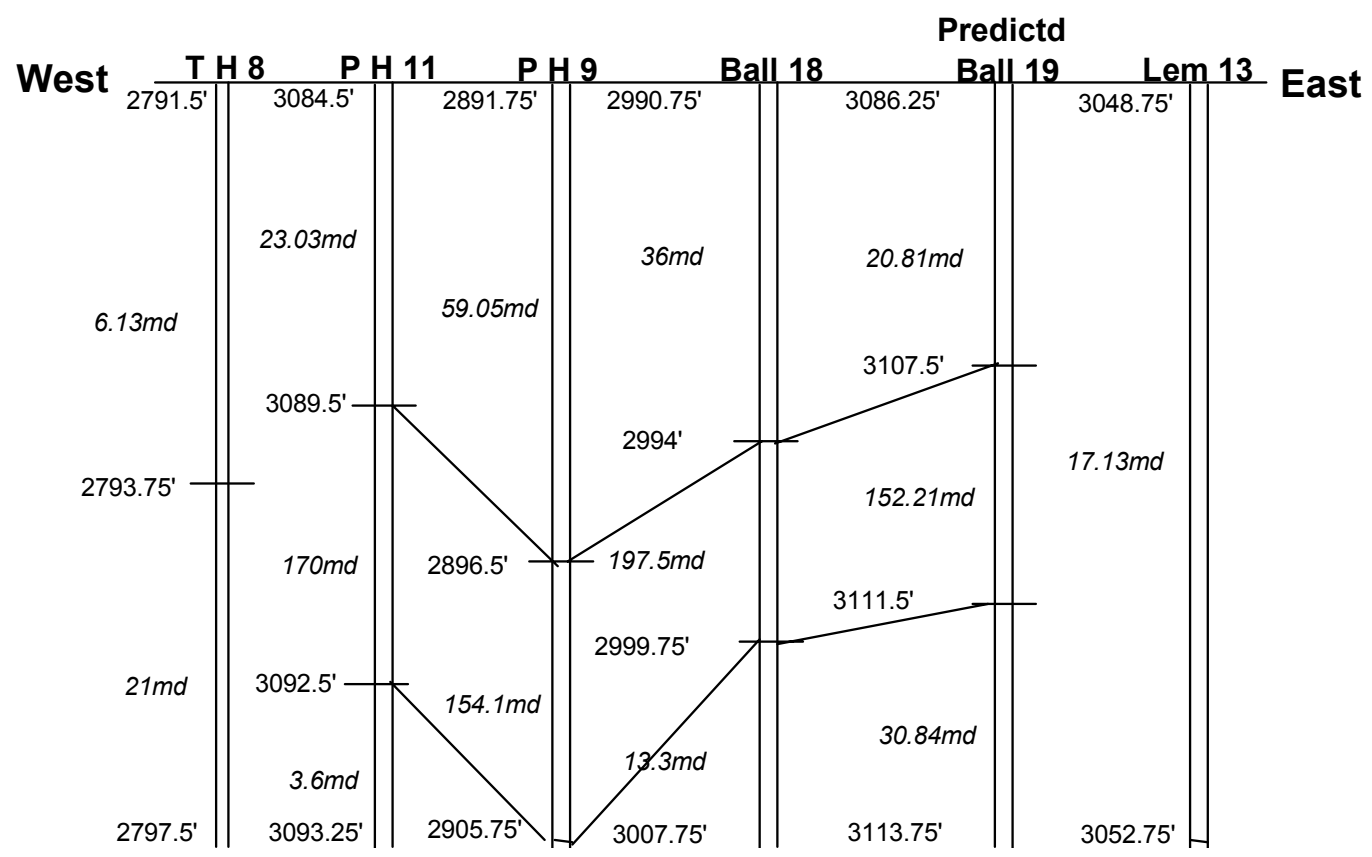

Figure H. 5: Correlation of flow units between predicted Ball 19 and original five cored wells.

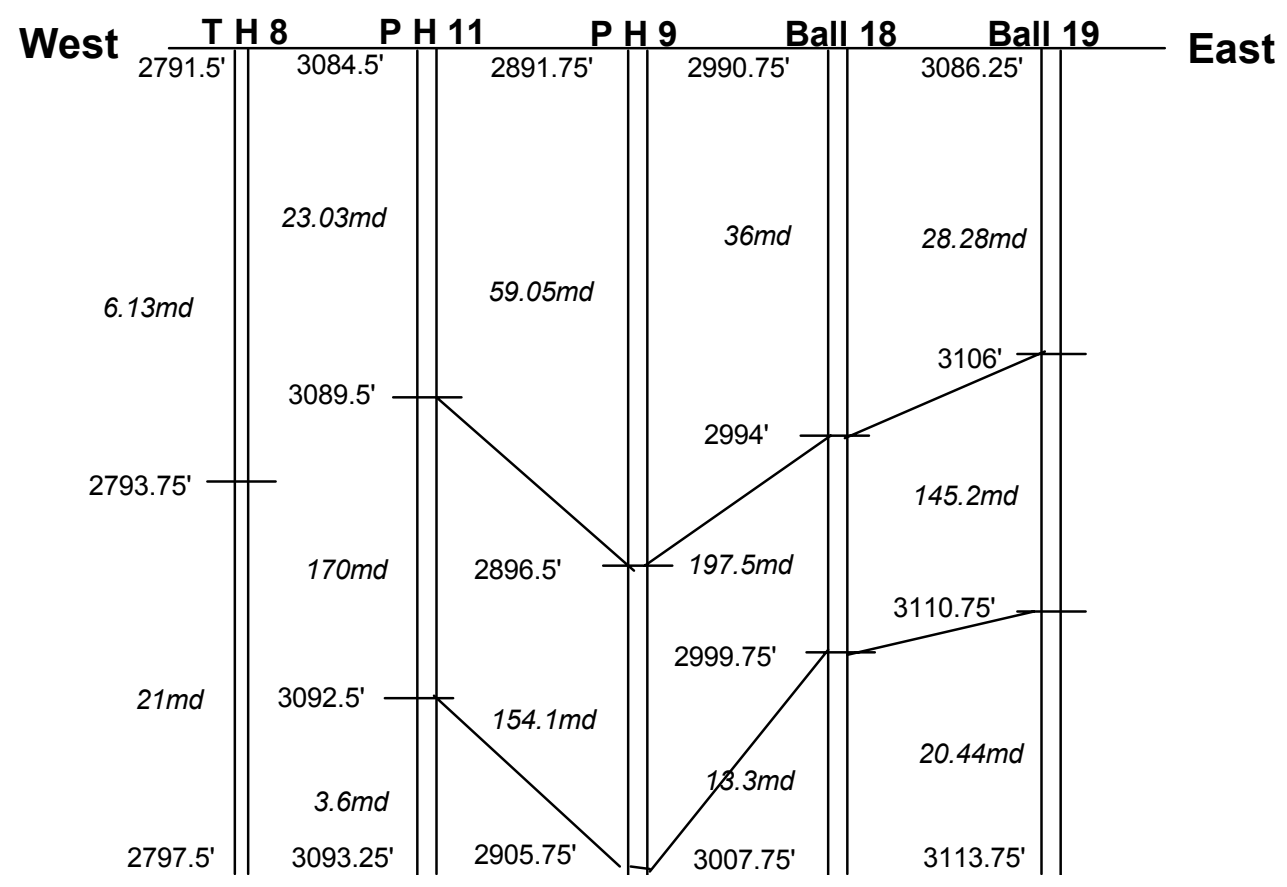

Figure H. 6: Correlation of flow units from five cored wells (except Lemasters 13). 


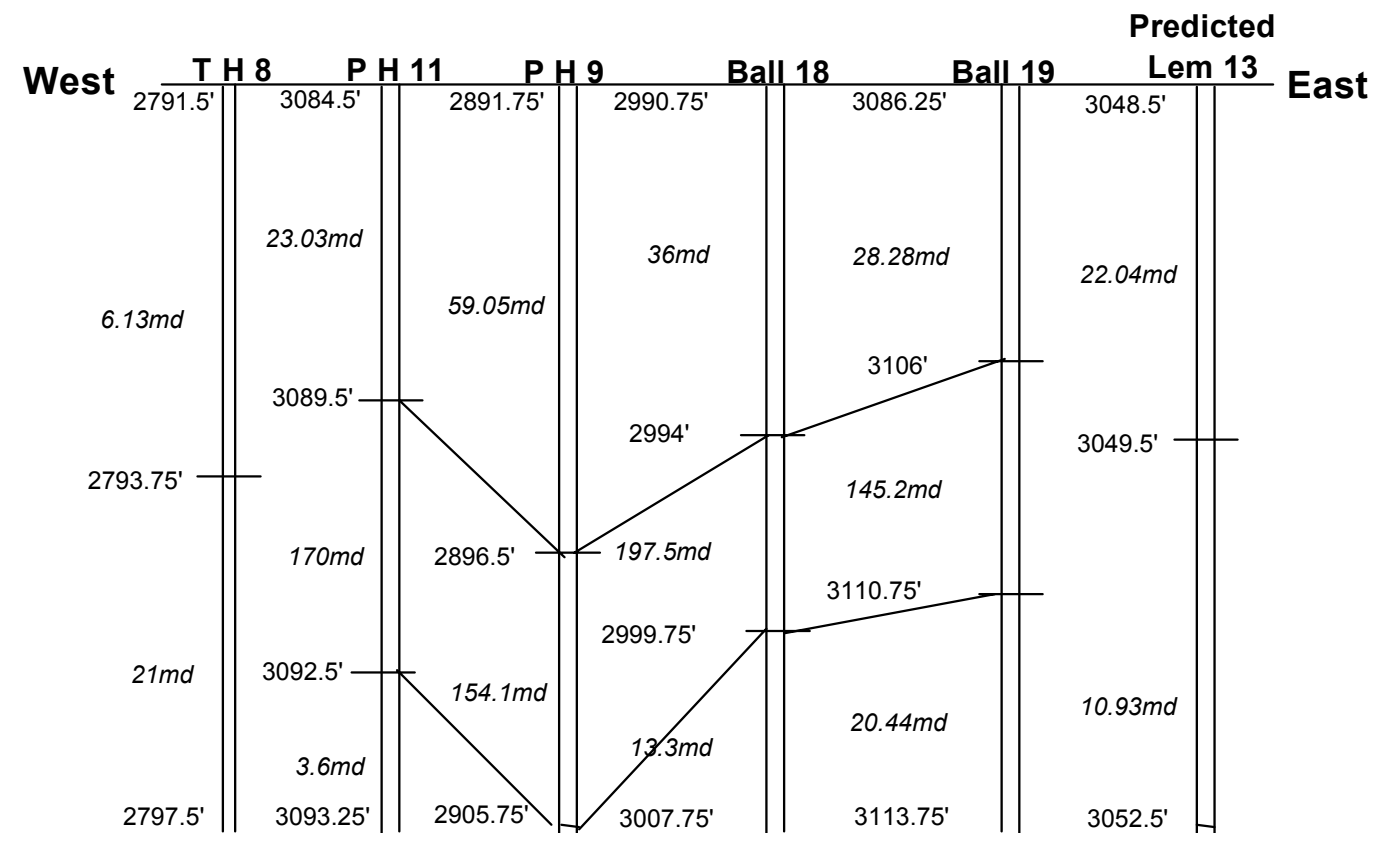

Figure H. 7: Correlation of flow units between predicted Lemasters 13 and original five cored wells.

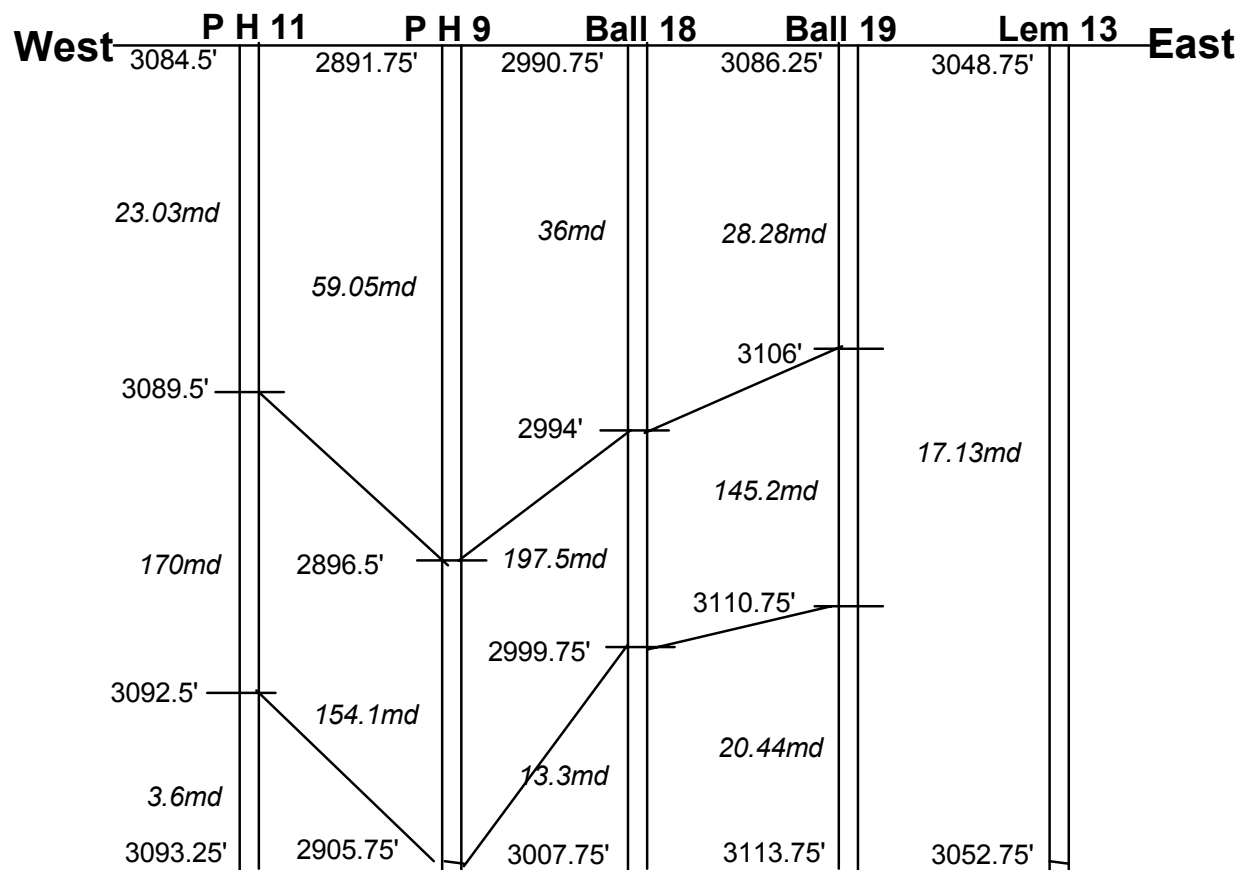

Figure H. 8: Correlation of flow units from five cored wells (except T. H. 8). 


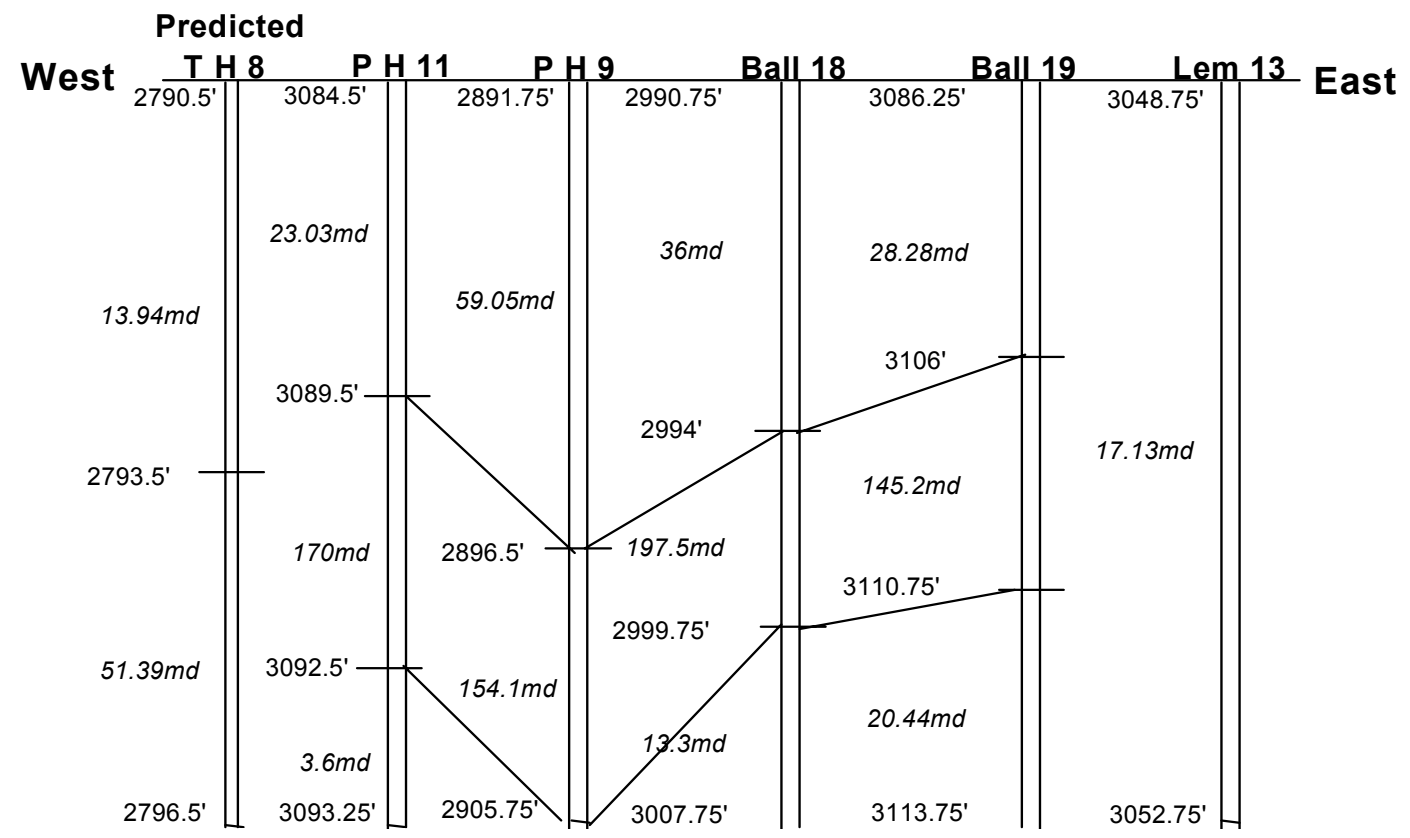

Figure H. 9: Correlation of flow units between predicted TH 8 and original five cored wells.

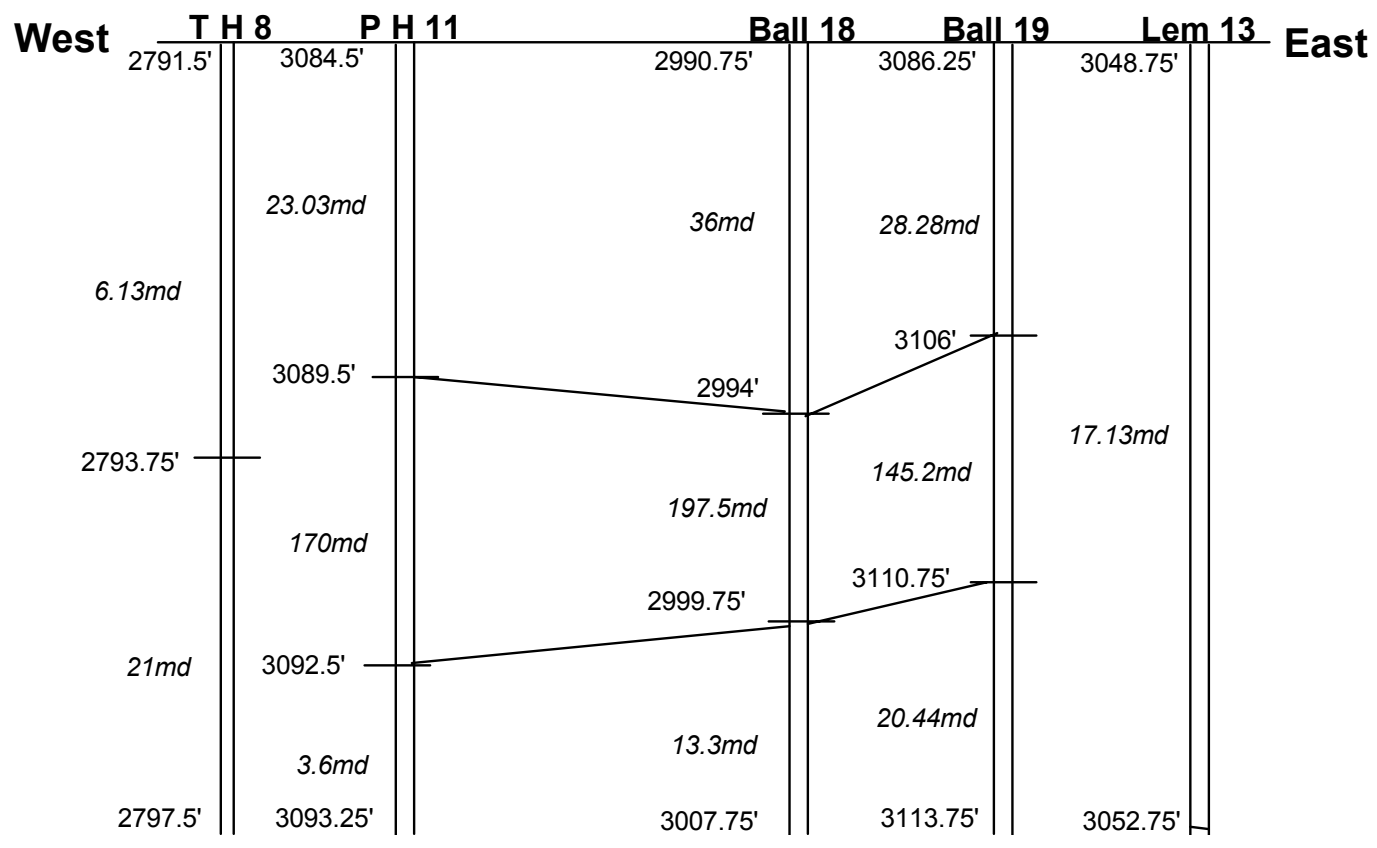

Figure H. 10: Correlation of flow units from five cored wells (except PH 9). 


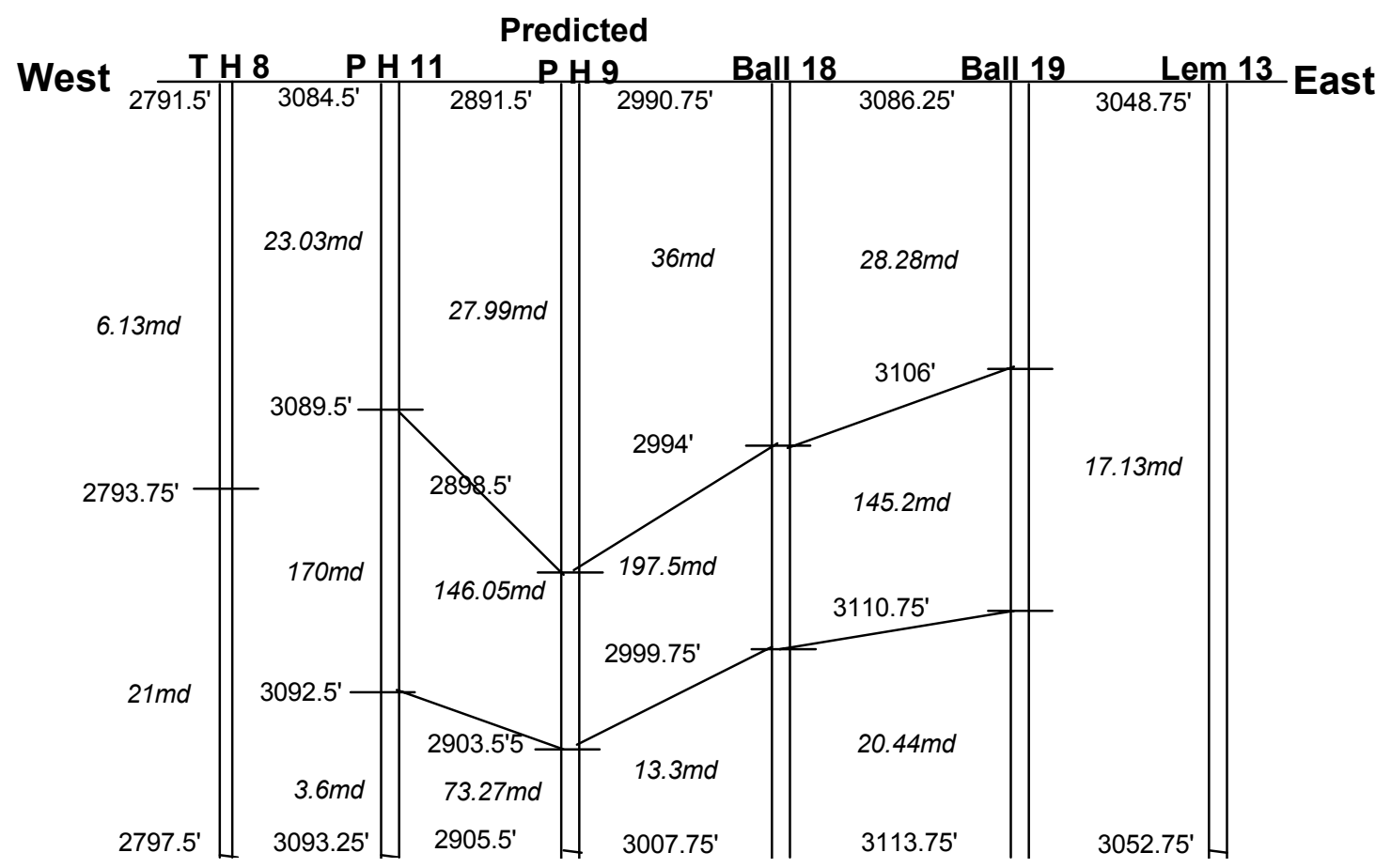

Figure H. 11: Correlation of flow units between predicted PH 9 and original five cored wells.

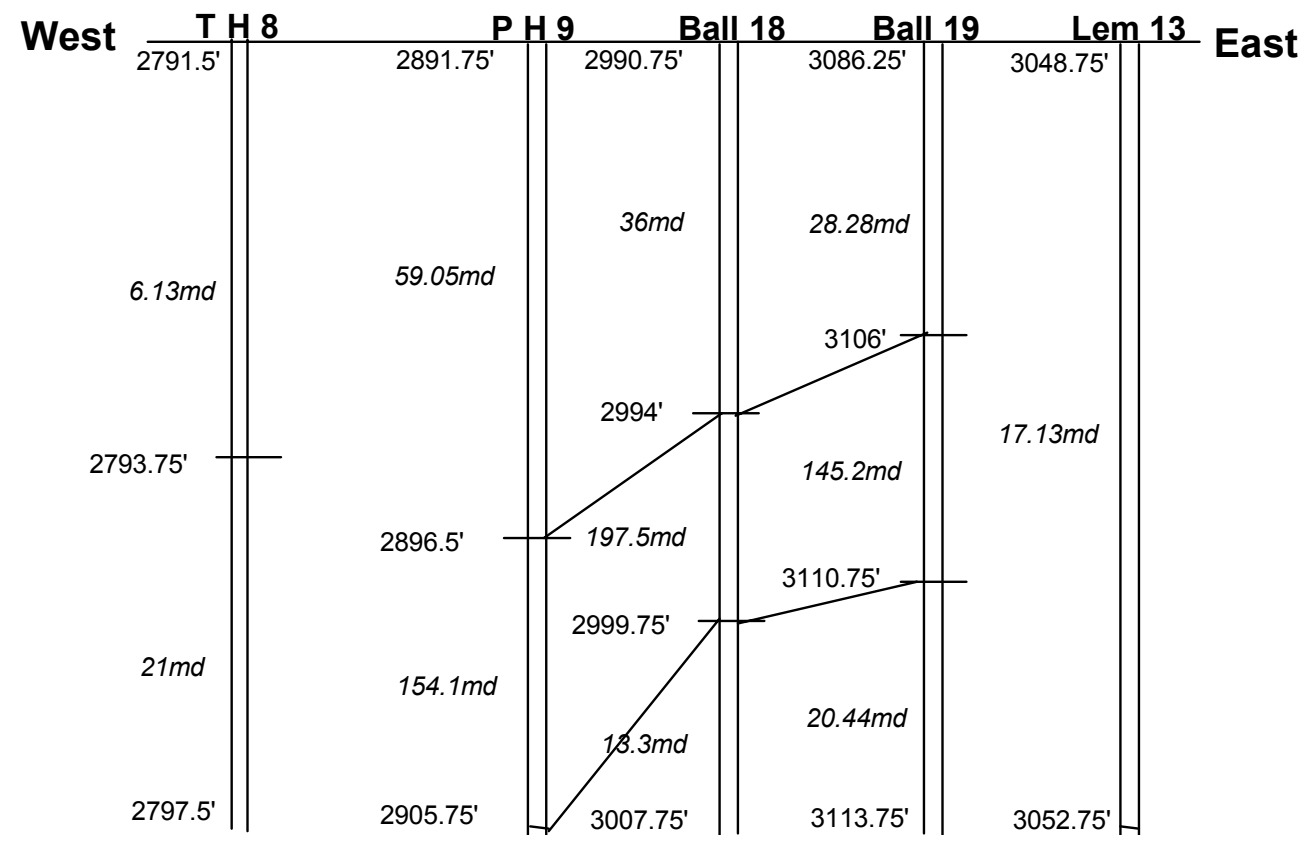

Figure H. 12: Correlation of flow units from five cored wells (except PH 11). 


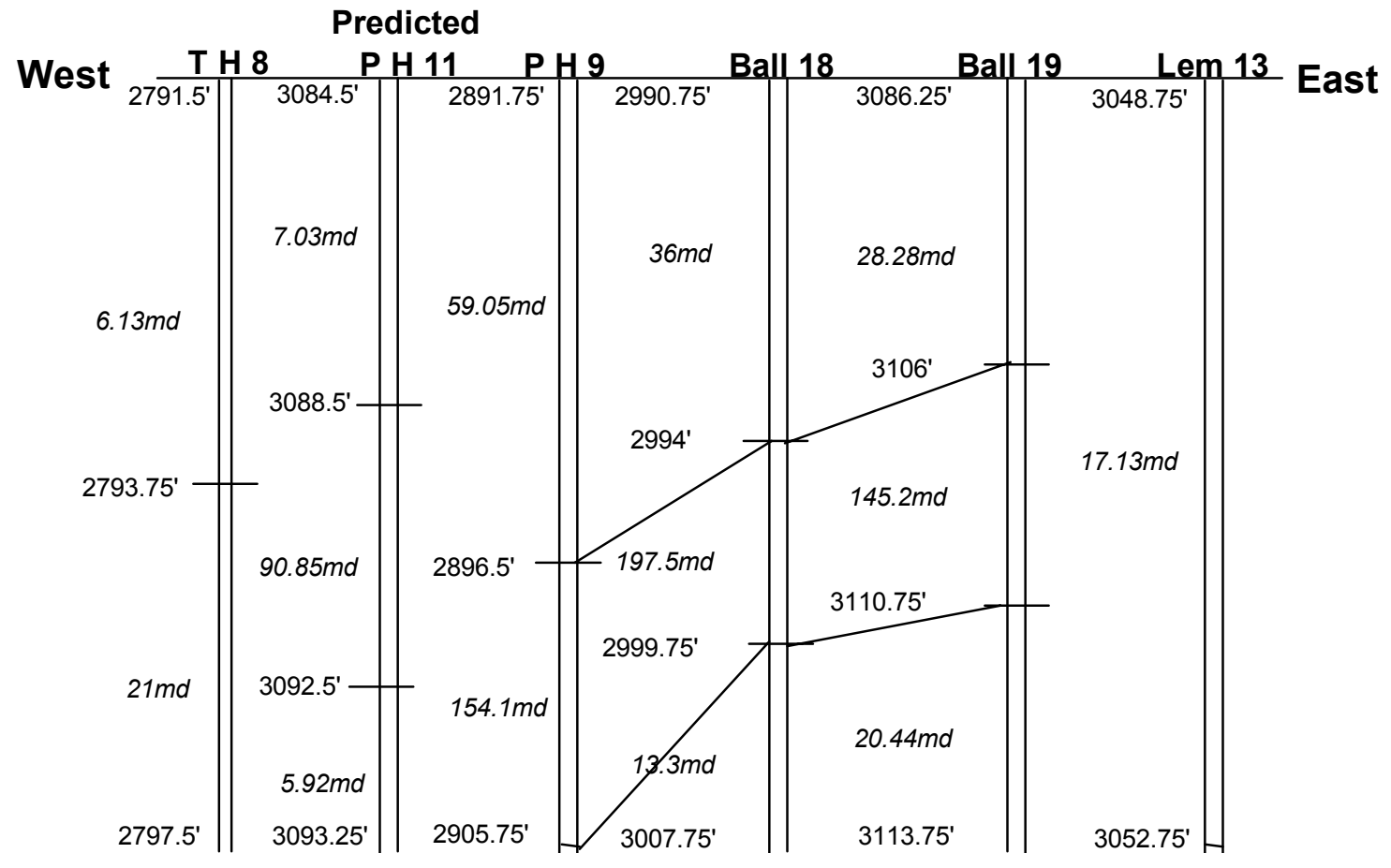

Figure H. 13: Correlation of flow units between predicted PH 11 and original five cored wells. 